\title{
Data Compilation for AGR-3/4 Matrix Ring Blank Lot ARB-B1
}

\author{
John D. Hunn, Michael P. Trammell, \\ and Fred C. Montgomery
}

\section{Revision 0}

September 2011

\author{
Prepared for the \\ United States Department of Energy - \\ Office of Nuclear Energy \\ under the \\ Next Generation Nuclear Plant - \\ Advanced Gas Reactor Fuel Development Program
}




\section{DOCUMENT AVAILABILITY}

Reports produced after January 1, 1996, are generally available free via the U.S. Department of Energy (DOE) Information Bridge.

Web site http://www.osti.gov/bridge

Reports produced before January 1, 1996, may be purchased by members of the public from the following source.

National Technical Information Service 5285 Port Royal Road

Springfield, VA 22161

Telephone 703-605-6000 (1-800-553-6847)

TDD 703-487-4639

Fax 703-605-6900

E-mailinfo@ntis.fedworld.gov

Web site http://www.ntis.gov/support/ordernowabout.htm

Reports are available to DOE employees, DOE contractors, Energy Technology Data Exchange (ETDE) representatives, and International Nuclear Information System (INIS) representatives from the following source.

Office of Scientific and Technical Information P.O. Box 62

Oak Ridge, TN 37831

Telephone 865-576-8401

Fax 865-576-5728

E-mail reports@adonis.osti.gov

Web site http://www.osti.gov/contact.html

This report was prepared as an account of work sponsored by an agency of the United States Government. Neither the United States Government nor any agency thereof, nor any of their employees, makes any warranty, express or implied, or assumes any legal liability or responsibility for the accuracy, completeness, or usefulness of any information, apparatus, product, or process disclosed, or represents that its use would not infringe privately owned rights. Reference herein to any specific commercial product, process, or service by trade name, trademark, manufacturer, or otherwise, does not necessarily constitute or imply its endorsement, recommendation, or favoring by the United States Government or any agency thereof. The views and opinions of authors expressed herein do not necessarily state or reflect those of the United States Government or any agency thereof. 


\title{
Data Compilation for AGR-3/4 Matrix Ring Blank Lot ARB-B1
}

\author{
John D. Hunn, Michael P. Trammell, and Fred C. Montgomery \\ Oak Ridge National Laboratory
}

This document is a compilation of compacting and characterization data for the matrix ring blank set ARB-B1. These ring blanks were made using a graphite/resin blend of natural and synthetic graphite flake mixed with Hexion SD-1708 novolac resin (Blend I). The Blend I material was provided to Oak Ridge National Laboratory (ORNL) by Babcock \& Wilcox (B\&W). Thirty of the $26 \mathrm{~mm}$ diameter, $63 \mathrm{~mm}$ long solid cylindrical ring blanks were shipped from ORNL to Idaho National Laboratory (INL) for machining and possible insertion into the Advanced Gas Reactor Fuel Development and Qualification (AGR) program's third irradiation test (AGR-3/4). A previous batch of ring blanks (lot RDKRS), made from an ORNL produced graphite/resin blend of natural and synthetic graphite flake mixed with Hexion SC-1008 resole resin, has also been shipped from ORNL to INL (see data compilation report ORNL/TM-2011/127).

In the AGR-3/4 irradiation experiment, each $12.3 \mathrm{~mm}$ diameter, $12.5 \mathrm{~mm}$ long cylindrical fuel compact will contain twenty designed-to-fail (DTF) particles distributed along the centerline of the compact. The DTF coating is a high density, high anisotropy pyrocarbon coating of nominal $20 \mu \mathrm{m}$ thickness that is deposited directly on the kernel. This coating is designed to fail early in the AGR-3/4 irradiation test, resulting in a controlled release of fission products which can be analyzed to provide data on fission product transport. The DTF will be surrounded by standard tristructural isotropic (TRISO) "driver fuel" particles. Information on the DTF and driver fuel particles can be found in ORNL/TM-2011-109, "Data Compilation for AGR-3/4 Designed-toFail (DTF) Fuel Particle Batch LEU03-07DTF," and ORNL/TM-2007/019, "Data Compilation for AGR-3/4 Driver Fuel Coated Particle Composite LEU03-09T." Information on the fuel compacts can be found in ORNL/TM-2011/124, "Data Compilation for AGR-3/4 Designed-toFail (DTF) Fuel Compact Lot (LEU03-10T-OP2/LEU03-07DTF-OP1)-Z." Each irradiation test capsule will contain four compacts stacked in a single column. Matrix ring blanks will be machined with a center bore diameter $\sim 100-150 \mu \mathrm{m}$ larger than the diameter of the fuel compacts, so that the fuel stack can be placed inside the matrix ring. The outer diameter and length of the matrix rings will also be machined. A graphite sleeve will be machined to surround the matrix ring. During irradiation, fission products released by the DTF will migrate out of the compacts into these surrounding matrix and graphite rings.

The ARB-B1 matrix ring blank set did not meet all the product specifications for compact matrix ring blanks in section 1.05 of the AGR-3/4 DTF Fuel and Capsule Component Material Specifications (SPC-1214, Rev. 1). Nineteen ring blanks had an average density slightly above the specified limit of $1.80 \mathrm{~g} / \mathrm{cm}^{3}$. These ring blanks were used for destructive impurity analysis or retained at ORNL and the 30 shipped to INL were within the specified density limits. The average Al impurity content $(24.6 \mathrm{ppmw})$ was above the specified limit of $\leq 20 \mathrm{ppmw}$. In addition, one of the samples analyzed for $U$ contamination had an abnormally high value (1.95 ppmw), which was above the specified limit of $\leq 0.5 \mathrm{ppmw}$. These three non-conformances are documented in Appendices A - C. The final disposition for the ARB-B1 matrix ring blank set was to accept for possible use in the AGR-3/4 irradiation experiment. 


\section{Table of Contents}

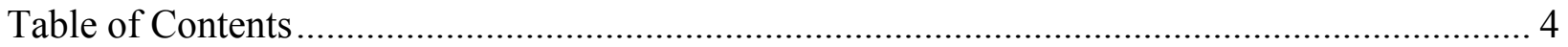

1 Material Identification Record for ARB-B1 Ring Blanks ......................................... 5

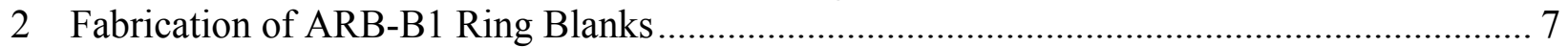

3 Impurity Analysis of Matrix, Resin, and Graphite ........................................................ 14

4 Characterization of ARB-B1 Ring Blanks.................................................................. 20

Appendix A: Non-Conformance Report for Matrix Density ................................................ 39

Appendix B: Non-Conformance Report for Al Content ....................................................... 41

Appendix C: Non-Conformance Report for U Contamination........................................... 43

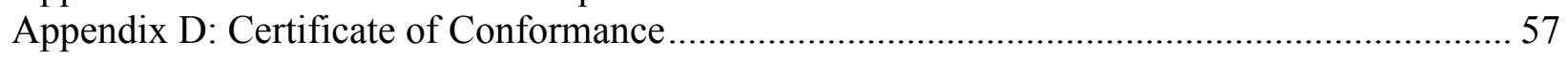




\section{Material Identification Record for ARB-B1 Ring Blanks}

Table 1 lists the materials used to make the ARB-B1 ring blanks. Thirty completed ring blanks were shipped to INL in July of 2011. Eight ring blanks were retained at ORNL and 12 ring blanks were consumed at ORNL for analysis of impurity content. Table 2 lists the disposition of each ring blank. The graphite/resin blend (Blend I) used to fabricate the ARB-B1 ring blanks was provided by $\mathrm{B} \& \mathrm{~W}$. The following page shows a copy of an email from $\mathrm{B} \& \mathrm{~W}$ documenting the make-up of Blend I.

Table 1. Material identification record for ring blank lot ARB-B1

\begin{tabular}{|c|c|l|}
\hline Sample ID & Parent Material & \multicolumn{1}{|c|}{ Notes } \\
\hline 3482 & & \\
\hline KRB2000 & Asbury Graphite Mills & Natural graphite \\
\hline SD-1708 & SGL Carbon & Synthetic graphite \\
\hline Hexa & Hexion & Novolac resin \\
\hline & $\begin{array}{c}63.37 \mathrm{wt} \% 3482 \\
\text { Blend I }\end{array}$ & Hexamethylenetetramine resin hardener \\
& $\begin{array}{c}\text { Graphite/resin blend received from B\&W on } \\
\text { April 7, 2011 (see copy of email at end of this } \\
\text { section) }\end{array}$ \\
\hline ARB-B1-G\#\#\# & Blend I $\%$ KRB2000 & Ring blanks numbered G001 through G050 \\
\hline ARB-B1-Z\#\#\# & ARB-B1-G\#\#\# & $\begin{array}{l}\text { Ring blanks, numbered Z001 through Z050 } \\
\text { One to one correspondence to G\#\#\# recorded on } \\
\text { IRF20C (section 4) }\end{array}$ \\
\hline
\end{tabular}

Table 2. Disposition of ARB-B1 ring blanks

\begin{tabular}{|c|c|c|c|}
\hline \multicolumn{2}{|c|}{ Sent to INL } & Retained at ORNL & Consumed during analysis \\
\hline ARB-B1-Z001 & ARB-B1-Z024 & ARB-B1-Z006 & ARB-B1-Z003 \\
\hline ARB-B1-Z002 & ARB-B1-Z028 & ARB-B1-Z008 & ARB-B1-Z014 \\
\hline ARB-B1-Z004 & ARB-B1-Z029 & ARB-B1-Z012 & ARB-B1-Z015 \\
\hline ARB-B1-Z005 & ARB-B1-Z031 & ARB-B1-Z016 & ARB-B1-Z019 \\
\hline ARB-B1-Z007 & ARB-B1-Z032 & ARB-B1-Z030 & ARB-B1-Z025 \\
\hline ARB-B1-Z009 & ARB-B1-Z033 & ARB-B1-Z038 & ARB-B1-Z026 \\
\hline ARB-B1-Z010 & ARB-B1-Z034 & ARB-B1-Z049 & ARB-B1-Z027 \\
\hline ARB-B1-Z011 & ARB-B1-Z037 & ARB-B1-Z050 & ARB-B1-Z035 \\
\hline ARB-B1-Z013 & ARB-B1-Z039 & & ARB-B1-Z036 \\
\hline ARB-B1-Z017 & ARB-B1-Z042 & & ARB-B1-Z040 \\
\hline ARB-B1-Z018 & ARB-B1-Z043 & & ARB-B1-Z041 \\
\hline ARB-B1-Z020 & ARB-B1-Z045 & & ARB-B1-Z044 \\
\hline ARB-B1-Z021 & ARB-B1-Z046 & & \\
\hline ARB-B1-Z022 & ARB-B1-Z047 & & \\
\hline ARB-B1-Z023 & ARB-B1-Z048 & & \\
\hline
\end{tabular}


From: "Treadway, Brandon D." <bdtreadway@babcock.com>

Date: April 7, 2011 7:56:28 AM EDT

To: "Hunn, John D." <hunnjd@ornl.gov>

Cc: Jeffrey A Phillips <Jeffrey.Phillips@inl.gov>, "Niedzialek, Scott E."

$<$ seniedzialek@babcock.com>

Subject: Blend I and Blend III Shipment

John,

The FedEx tracking number for the shipment of Blend I ( $~ 8 \mathrm{~kg})$ is 478764566050 and will be on-site at ORNL by 10:30 am. The $8 \mathrm{~kg}$ of Blend III will ship today and I will provide you with its tracking number. The makeup of the two blends is:

\section{Blend I}

Pulverized Wt (lb)

75.75

Hexion SD-1708 Wt (lb)

15.00

Nat Graphite Asbury 3482 Wt (lb)

48.00

Syn Graphite SGL Carbon KRB2000 Wt (lb)

12.00

Hexa $5 \%$ of Resin (lb)

0.75

Requested Size specification

10-12 micron (one pass) (Results: Beginning of run avg. $=8.76 \mu$; End of run avg. $=10.39 \mu) *$ Packaging $5 \mathrm{lbs}$ in large Ziploctype bags

\section{Blend III}

Pulverized Wt (Ib)

75.75

Plenco 14043 Wt (lb)

Nat Graphite Asbury 3482 Wt (lb)

48.00

Syn Graphite SGL Carbon KRB2000 Wt (lb)

12.00

Hexa $5 \%$ of Resin (lb)

0.75

Size specification

10-12 micron (one pass) (Results: Beginning of run avg. $=9.15 \mu$; End of run avg. $=9.53 \mu$ ) Packaging $5 \mathrm{lbs}$ in large Ziploctype bags

Best regards, 


\section{Fabrication of ARB-B1 Ring Blanks}

Natural graphite (Asbury Graphite Mills 3482), synthetic graphite (SGL Carbon KRB2000), thermosetting resin (Hexion SD-1708), and hexamethylenetetramine hardener were combined to make a matrix precursor graphite/resin blend (Blend I). This blend was provided to ORNL by $\mathrm{B} \& \mathrm{~W}$. In order to fit the required amount of graphite/resin blend into the compacting die, the density of the powder was increased by pressing cold at $800 \mathrm{lbs}-\mathrm{f}$ in a $26.2 \mathrm{~mm}$ diameter die and regranulating into coarser powder. This also made the material, which was initially a very fine powder, easier to transfer into the die. Compacting charges of the cold-pressed graphite/resin blend granules were weighed out and labeled ARB-B1-G001 through G052.
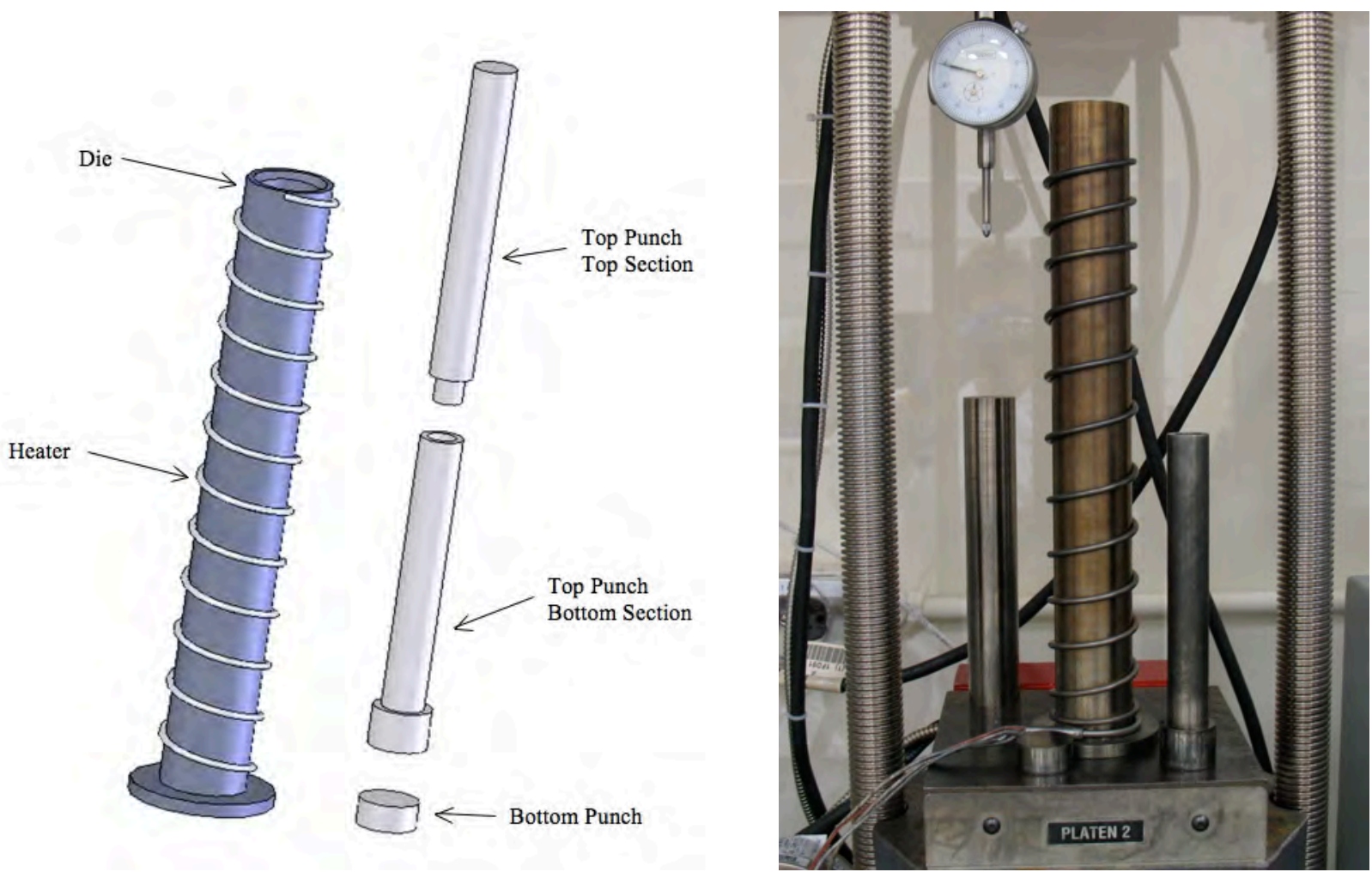

Figure 1. 26.2-mm-diameter die set used for ARB-B1 ring blank fabrication.

Ring blanks were fabricated in accordance with AGR-COMP-SOP-11R1, "Standard Operating Procedures for Production of AGR 3/4 Matrix Ring Blanks." The cold-pressed graphite/resin blend granules were compacted using a specially designed single-acting die set and a manual Carver hydraulic press (Figure 1). A coiled cable heater spiraling along the length of the die was used to heat the die and a temperature controller was used to maintain the desired die temperature. This coil heater allowed for more uniform heating along the entire die length (30 $\mathrm{cm}$ ) compared to previously used band heaters. This was important because the matrix precursor material filled almost the entire die volume prior to pressing and the temperature of the graphite/resin blend was a critical parameter for successful compacting with the Hexion SD-1708 resin. Even with the coil heater, there was still some temperature variation over the entire length of the die. For the ARB-B1 ring blank fabrication, the lowest and highest temperatures observed on the outside surface of the die just before compacting were kept between 140 and $150^{\circ} \mathrm{C}$. With 
the die within this desired temperature range, the pre-slugged granules were added quickly (within 5 seconds) into the die. To reduce pressing time, the first section of the punch was inserted into the die and rapidly pressed by hand. The second punch section was then placed onto the first section and the die was inserted between the manual Carver press platens. Pressing was performed at $\sim 3 \mathrm{~mm} / \mathrm{sec}$ until a target force of $5000 \mathrm{lbs}-\mathrm{f}$ was achieved (41 MPa maximum pressure). To allow for resin curing, this position (not pressure) was maintained for 10 minutes before ejecting the ring blank from the die. A dial gauge was used to monitor the distance between the press platens during this stage. In total, 50 "green" ring blank cylinders were compacted. The green ring blanks retained the material designation of ARB-B1-G001 through G052.

Fifty green ring blanks were carbonized and heat treated according to AGR-COMP-SOP-04R0, "Standard Operating Procedure for Carbonizing Compacts," and AGR-COMP-SOP-05R1, "Standard Operating Procedure for Heat-treating Compacts." Two of the green ring blanks (G004 and G048) were rejected after compacting due to fabrication problems. Green ring blanks were slowly heated at $1{ }^{\circ} \mathrm{C} / \mathrm{min}$ to $950^{\circ} \mathrm{C}$ in flowing helium atmosphere and then held at $950^{\circ} \mathrm{C}$ for 1 hour. The heating rate was less than used for smaller diameter AGR fuel compacts $\left(\sim 5^{\circ} \mathrm{C} / \mathrm{min}\right)$ or for RDKRS ring blanks $\left(2^{\circ} \mathrm{C} / \mathrm{min}\right)$, because extra time was needed to allow evolved gases to diffuse out of these less permeable ring blank cylinders and prevent cracking. The carbonization furnace was allowed to cool to room temperature under no power before removing the carbonized ring blanks for transfer to the heat-treatment furnace. Heat-treatment was performed under vacuum after back-filling with argon three times. Using the standard AGR compact heat-treatment process, carbonized ring blanks were heated at $20^{\circ} \mathrm{C} / \mathrm{min}$ to $1800^{\circ} \mathrm{C}$, held for 1 hour, cooled at $<20^{\circ} \mathrm{C} / \mathrm{min}$ to $700^{\circ} \mathrm{C}$, then cooled under no power to room temperature before removing. Figure 2 shows an image of a ring blank made with this process.

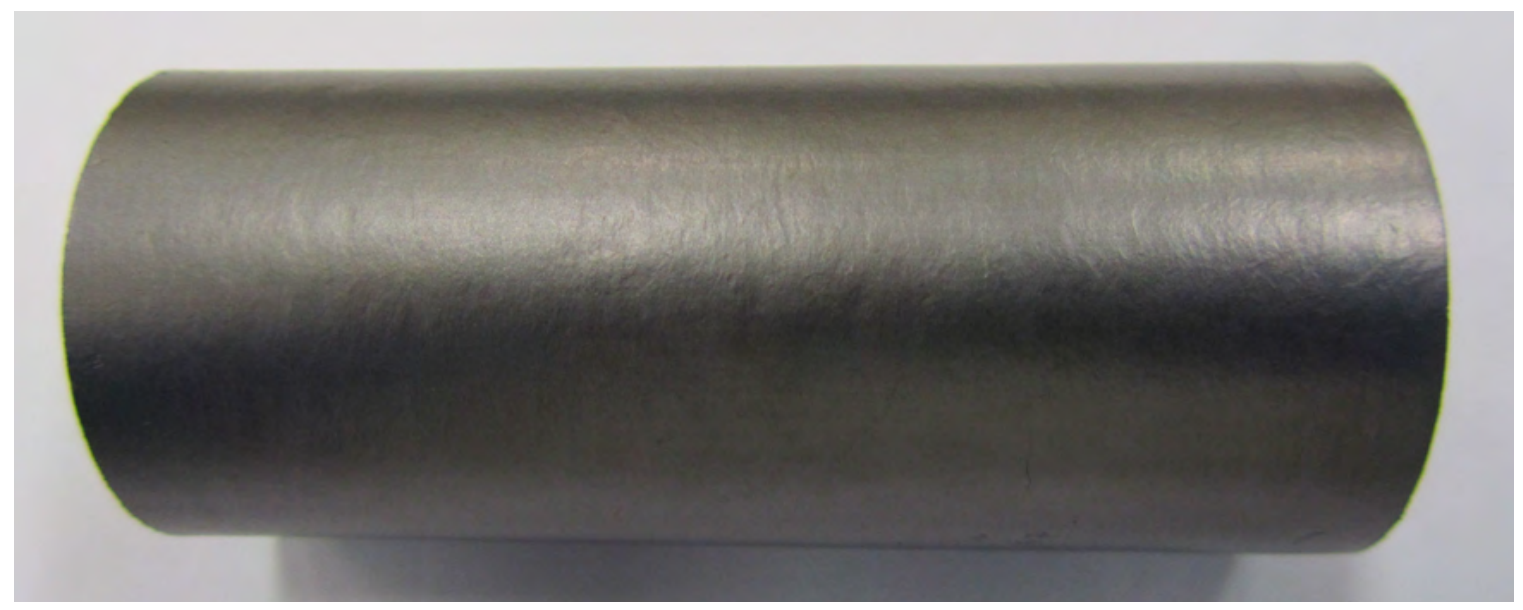

Figure 2. Typical ARB-B1 ring blank.

Cylinder weight and dimensions were measured after compacting, carbonization, and heattreatment. Table 3 lists the average change after each step. All of the ring blanks shrunk in diameter after carbonization, with the change ranging from $-2.2 \%$ to $-1.2 \%$. In contrast, the change in length after carbonization varied from $-2.3 \%$ to $+0.8 \%$. The observation of reduced shrinkage in length or even growth in some samples was probably mostly due to the formation of fissures perpendicular to the axis of the cylinder. These fissures were visible on the surface of 
some of the ring blanks (Figure 3 ). There was essentially no change in diameter after $1800^{\circ} \mathrm{C}$ heat-treatment, but length increased slightly, also possibly due to the presence of these fissures. Mass loss after carbonization was consistent, with a slight additional mass loss after heattreatment. The total mass loss was even more consistent. The observed variation in the density was due to the variation in shrinkage along the length.

Table 3. Average percent change due to furnace treatment of ARB-B1 ring blanks

\begin{tabular}{|l|c|c|c|}
\hline Property & $\begin{array}{c}\text { As-pressed to } \\
\text { Carbonized }\end{array}$ & $\begin{array}{c}\text { Carbonized to } \mathbf{1 8 0 0}^{\circ} \mathbf{C} \\
\text { Heat-treated }\end{array}$ & $\begin{array}{c}\text { As-pressed to 1800 } \\
\text { Heat-treated }\end{array}$ \\
\hline Diameter & $-1.8 \pm 0.3 \%$ & $0.06 \pm 0.11 \%$ & $-1.7 \pm 0.3 \%$ \\
\hline Length & $-0.8 \pm 0.9 \%$ & $0.43 \pm 0.14 \%$ & $-0.4 \pm 0.8 \%$ \\
\hline Mass & $-9.7 \pm 0.2 \%$ & $-0.3 \pm 0.1 \%$ & $-9.95 \pm 0.17 \%$ \\
\hline Average Density & $-5.6 \pm 1.3 \%$ & $-0.9 \pm 0.3 \%$ & $-6.4+1.2 \%$ \\
\hline \pm values are standard deviations from the mean \\
\hline
\end{tabular}

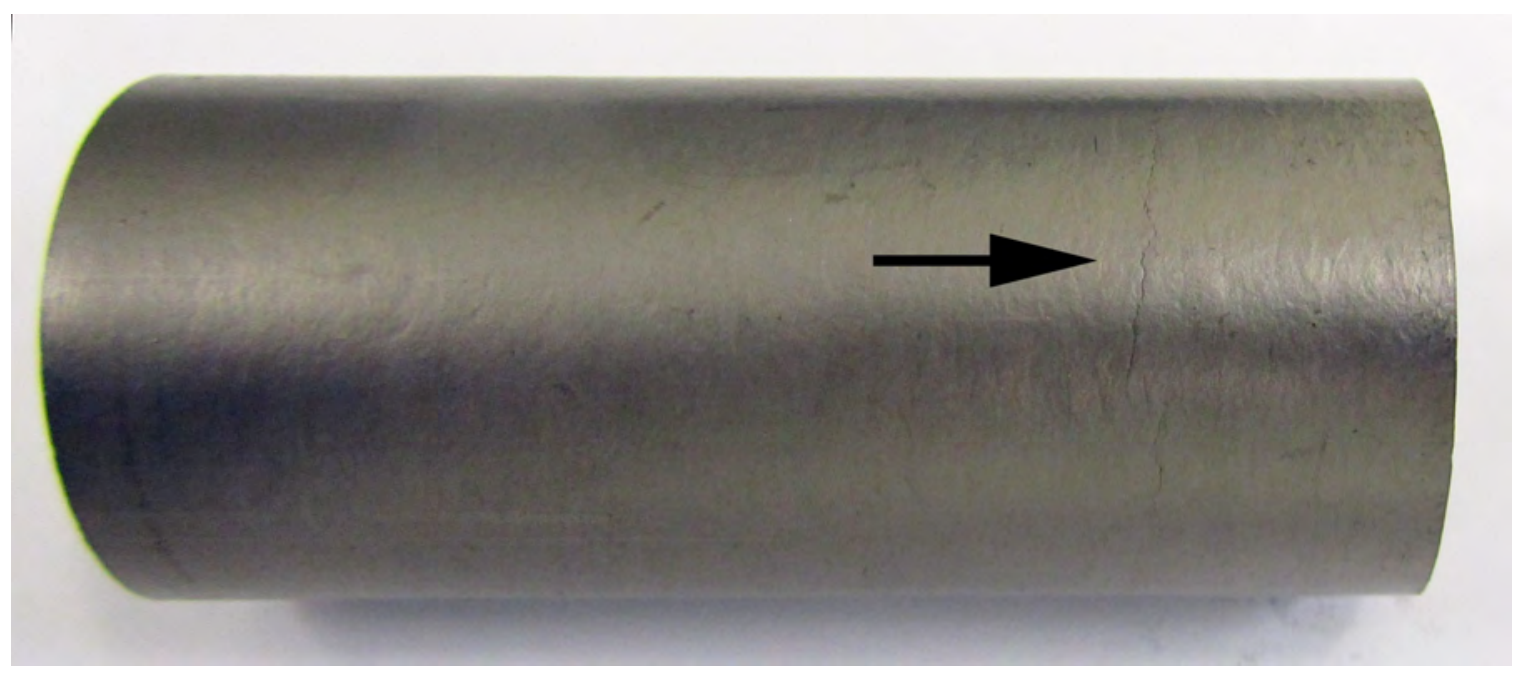

Figure 3. Fissure at surface of ARB-B1 ring blank.

For comparison, Table 4 lists the average changes observed during carbonization and heattreatment of the RDKRS ring blanks. Variation in diametrical shrinkage and weight loss was similar between the two ring blank sets. Length change after carbonization was significantly more consistent for the RDKRS ring blanks. All the RDKRS ring blanks shrunk in length, with the percent change ranging from $-2.7 \%$ to $-4.1 \%$.

Table 4. Average percent change due to furnace treatment of RDKRS ring blanks

\begin{tabular}{|l|c|c|c|}
\hline Property & $\begin{array}{c}\text { As-pressed to } \\
\text { Carbonized }\end{array}$ & $\begin{array}{c}\text { Carbonized to } 1800 \\
\text { Heat-treated }\end{array}$ & $\begin{array}{c}\text { As-pressed to } \mathbf{~ 1 8 0 0}^{\circ} \mathbf{C} \\
\text { Heat-treated }\end{array}$ \\
\hline Diameter & $-1.60 \pm 0.13 \%$ & $-0.06 \pm 0.09 \%$ & $-1.66 \pm 0.15 \%$ \\
\hline Length & $-3.3 \pm 0.3 \%$ & $0.08 \pm 0.14 \%$ & $-3.2 \pm 0.3 \%$ \\
\hline Mass & $-9.0 \pm 0.3 \%$ & $-0.28 \pm 0.03 \%$ & $-9.3 \pm 0.3 \%$ \\
\hline Average Density & $-2.8 \pm 0.4 \%$ & $-0.2 \pm 0.2 \%$ & $-3.0 \pm 0.4 \%$ \\
\hline \pm values are standard deviations from the mean \\
\hline
\end{tabular}


Figure 4 shows a comparison x-ray of an ARB-B1 ring blank versus an RDKRS ring blank imaged under the same conditions. The ARB-B1 ring blank $\mathrm{x}$-ray shows a few large fissures similar to what can be seen on the surface of some of the cylinders, but there are also many fine low density bands perpendicular to the cylinder axis that appear to be fissures throughout the length of the ring blank. The RDKRS ring blank did not show these fissures.
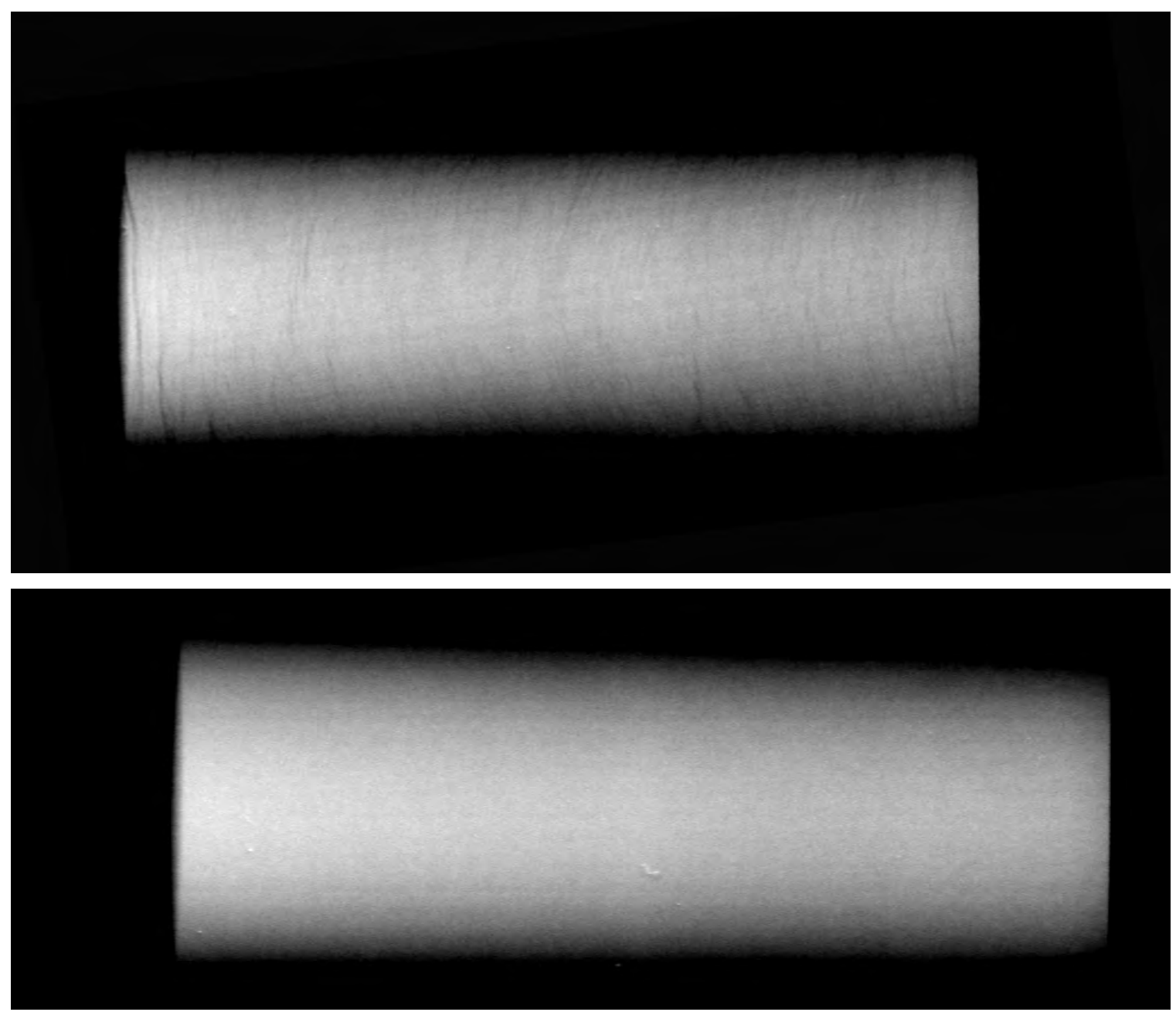

Figure 4. X-ray images of ARB-B1 ring blank (top) and RDKRS ring blank (bottom).

Figure 5 shows an x-ray image of the central section of another ARB-B1 ring blank. This image was obtained at INL using different imaging conditions which highlight the fissures more clearly. The ring blank in this image is oriented such that the end that was facing the fixed end of the die is down. There is a slight curvature to the fissures that corresponds to the dome shaped fracture surface that is observed when an ARB-B1 compact is broken. This is probably related to the way the ring blanks form in the die. Pressure is applied from the top and material is pushed to the bottom of the die with some drag along the walls. 


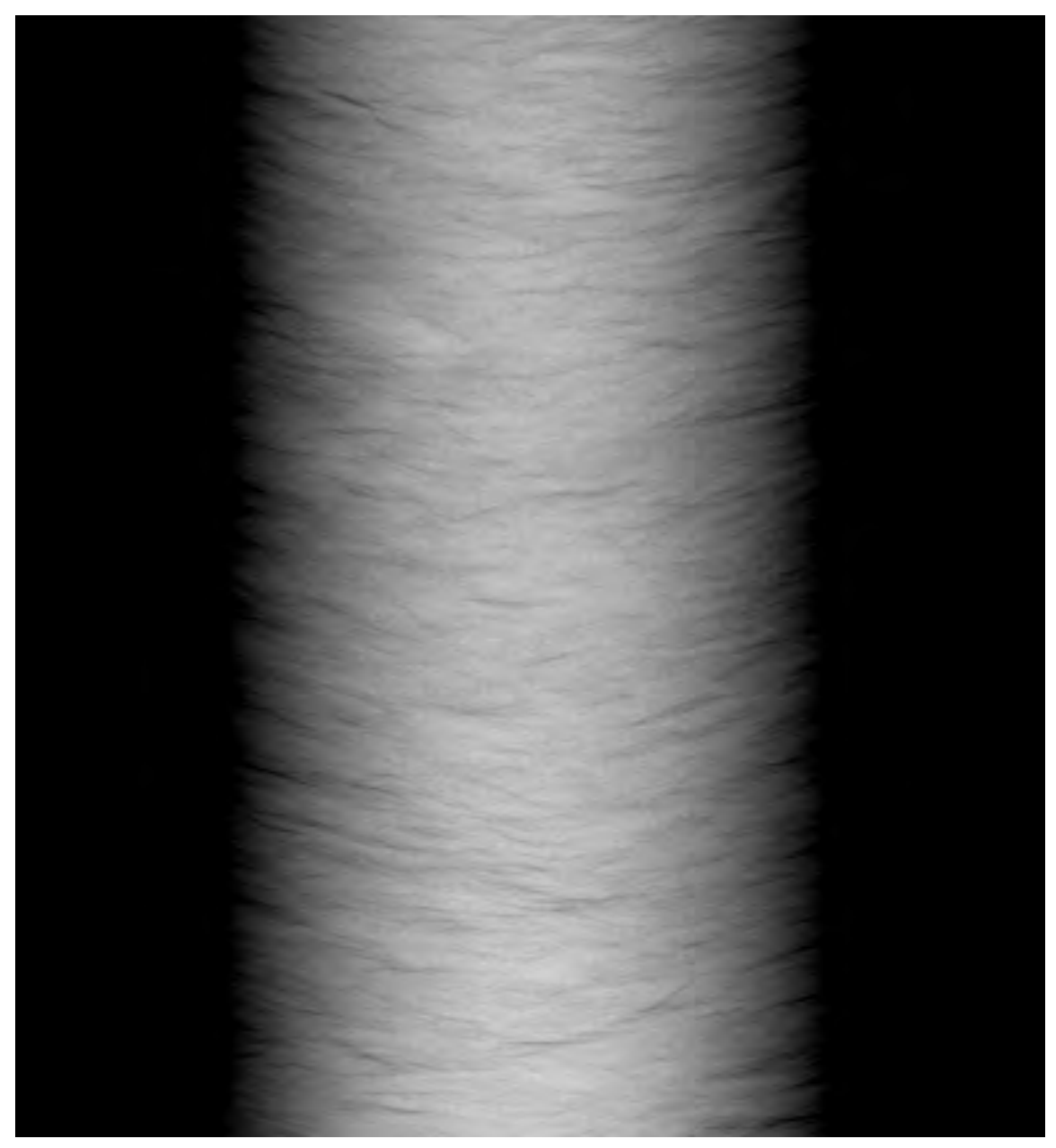

Figure 5. Section of ring blank x-rayed at INL.

After compacting, carbonization, and heat-treatment, all 50 of the heat-treated ring blanks were selected from ARB-B1-G001 through G052 for use (G004 and G048 were not heat treated due to problems with their compacting). As instructed in AGR-CHAR-PIP-20R1, "Product Inspection Plan for AGR-3/4 Ring Blank Lots," these 50 ring blanks were randomized and relabeled as ARB-B1-Z001 through Z050. However, pre-inspection of the ring blank dimensions and density indicated that 19 of the ring blanks had an average density above the specified limit of 1.80 $\mathrm{g} / \mathrm{cm}^{3}$. This was documented on NCR-X-AGR-11-01 (see Appendix A). The disposition of this non-conformance was to segregate the 19 non-conforming ring blanks, along with 1 additional ring blank selected out because it was the longest and had the lowest density. These 20 segregated ring blanks were then randomly assigned Z-numbers specified in PIP-20 for either destructive impurity analysis or for retention as ORNL archives. The 30 remaining conforming compacts were randomly assigned Z-numbers specified in PIP-20 for shipment to INL. A record of the original G-number for each Z-numbered ring blank can be found in inspection report form IRF-20C (section 4). After relabeling, the ring blanks were characterized for product acceptance according to product inspection plan PIP-20. This plan calls for measurement of ring blank length, diameter, mass, matrix density, uranium content and impurity content. Table 5 shows the verification record for the compact fabrication process conditions used. 
ORNL/TM-2011/272

Table 5. Summary of process conditions used in making ARB-B1 ring blanks

\begin{tabular}{|c|c|c|c|c|c|c|c|c|c|}
\hline \multirow[b]{2}{*}{ Ring blank ID } & \multicolumn{5}{|c|}{ Compacting and carbonization parameters } & \multicolumn{4}{|c|}{ Heat-treatment parameters } \\
\hline & $\begin{array}{c}\text { Max. Pressure } \\
(\mathrm{MPa})\end{array}$ & $\begin{array}{c}\text { Heating Rate } \\
\left({ }^{\circ} \mathrm{C} / \mathrm{min}\right)\end{array}$ & $\begin{array}{c}\text { Max. Temp. } \\
\left({ }^{\circ} \mathrm{C}\right)\end{array}$ & $\begin{array}{l}\text { Hold Time } \\
\text { (hr) }\end{array}$ & Atmosphere & $\begin{array}{c}\text { Heating Rate } \\
\left({ }^{\circ} \mathrm{C} / \mathrm{min}\right)\end{array}$ & $\begin{array}{l}\text { Max. Temp. } \\
\left({ }^{\circ} \mathrm{C}\right)\end{array}$ & $\begin{array}{l}\text { Hold Time } \\
\text { (hr) }\end{array}$ & Atmosphere \\
\hline ARB-B1-Z001 & 41 & 1 & 950 & 1 & flowing $\mathrm{He}$ & 20 & 1800 & 1 & vacuum \\
\hline ARB-B1-Z002 & 41 & 1 & 950 & 1 & flowing $\mathrm{He}$ & 20 & 1800 & 1 & vacuum \\
\hline ARB-B1-Z003 & 41 & 1 & 950 & 1 & flowing $\mathrm{He}$ & 20 & 1800 & 1 & vacuum \\
\hline ARB-B1-Z004 & 41 & 1 & 950 & 1 & flowing $\mathrm{He}$ & 20 & 1800 & 1 & vacuum \\
\hline ARB-B1-Z005 & 41 & 1 & 950 & 1 & flowing $\mathrm{He}$ & 20 & 1800 & 1 & vacuum \\
\hline ARB-B1-Z006 & 41 & 1 & 950 & 1 & flowing $\mathrm{He}$ & 20 & 1800 & 1 & vacuum \\
\hline ARB-B1-Z007 & 41 & 1 & 950 & 1 & flowing $\mathrm{He}$ & 20 & 1800 & 1 & vacuum \\
\hline ARB-B1-Z008 & 41 & 1 & 950 & 1 & flowing $\mathrm{He}$ & 20 & 1800 & 1 & vacuum \\
\hline ARB-B1-Z009 & 41 & 1 & 950 & 1 & flowing $\mathrm{He}$ & 20 & 1800 & 1 & vacuum \\
\hline ARB-B1-Z010 & 41 & 1 & 950 & 1 & flowing $\mathrm{He}$ & 20 & 1800 & 1 & vacuum \\
\hline ARB-B1-Z011 & 41 & 1 & 950 & 1 & flowing $\mathrm{He}$ & 20 & 1800 & 1 & vacuum \\
\hline ARB-B1-Z012 & 41 & 1 & 950 & 1 & flowing $\mathrm{He}$ & 20 & 1800 & 1 & vacuum \\
\hline ARB-B1-Z013 & 41 & 1 & 950 & 1 & flowing $\mathrm{He}$ & 20 & 1800 & 1 & vacuum \\
\hline ARB-B1-Z014 & 41 & 1 & 950 & 1 & flowing $\mathrm{He}$ & 20 & 1800 & 1 & vacuum \\
\hline ARB-B1-Z015 & 41 & 1 & 950 & 1 & flowing $\mathrm{He}$ & 20 & 1800 & 1 & vacuum \\
\hline ARB-B1-Z016 & 41 & 1 & 950 & 1 & flowing $\mathrm{He}$ & 20 & 1800 & 1 & vacuum \\
\hline ARB-B1-Z017 & 41 & 1 & 950 & 1 & flowing $\mathrm{He}$ & 20 & 1800 & 1 & vacuum \\
\hline ARB-B1-Z018 & 41 & 1 & 950 & 1 & flowing $\mathrm{He}$ & 20 & 1800 & 1 & vacuum \\
\hline ARB-B1-Z019 & 41 & 1 & 950 & 1 & flowing $\mathrm{He}$ & 20 & 1800 & 1 & vacuum \\
\hline ARB-B1-Z020 & 41 & 1 & 950 & 1 & flowing $\mathrm{He}$ & 20 & 1800 & 1 & vacuum \\
\hline ARB-B1-Z021 & 41 & 1 & 950 & 1 & flowing $\mathrm{He}$ & 20 & 1800 & 1 & vacuum \\
\hline ARB-B1-Z022 & 41 & 1 & 950 & 1 & flowing $\mathrm{He}$ & 20 & 1800 & 1 & vacuum \\
\hline ARB-B1-Z023 & 41 & 1 & 950 & 1 & flowing $\mathrm{He}$ & 20 & 1800 & 1 & vacuum \\
\hline ARB-B1-Z024 & 41 & 1 & 950 & 1 & flowing $\mathrm{He}$ & 20 & 1800 & 1 & vacuum \\
\hline ARB-B1-Z025 & 41 & 1 & 950 & 1 & flowing $\mathrm{He}$ & 20 & 1800 & 1 & vacuum \\
\hline
\end{tabular}

Task Manager Review Michael dramuel

Date $8 / 15 / 11$

QAS Review

Date

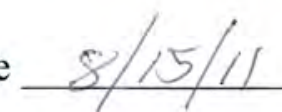


ORNL/TM-2011/272

Table 5 (continued). Summary of process conditions used in making ARB-B1 ring blanks

\begin{tabular}{|c|c|c|c|c|c|c|c|c|c|}
\hline \multirow[b]{2}{*}{ Ring blank ID } & \multicolumn{5}{|c|}{ Compacting and carbonization parameters } & \multicolumn{4}{|c|}{ Heat-treatment parameters } \\
\hline & $\begin{array}{c}\text { Max. Pressure } \\
(\mathrm{MPa})\end{array}$ & $\begin{array}{l}\text { Heating Rate } \\
\left({ }^{\circ} \mathrm{C} / \mathrm{min}\right)\end{array}$ & $\begin{array}{l}\text { Max. Temp. } \\
\left({ }^{\circ} \mathrm{C}\right)\end{array}$ & $\begin{array}{l}\text { Hold Time } \\
\text { (hr) }\end{array}$ & Atmosphere & $\begin{array}{l}\text { Heating Rate } \\
\left({ }^{\circ} \mathrm{C} / \mathrm{min}\right)\end{array}$ & $\begin{array}{l}\text { Max. Temp. } \\
\left({ }^{\circ} \mathrm{C}\right)\end{array}$ & $\begin{array}{l}\text { Hold Time } \\
\text { (hr) }\end{array}$ & Atmosphere \\
\hline ARB-B1-Z026 & 41 & 1 & 950 & 1 & flowing $\mathrm{He}$ & 20 & 1800 & 1 & vacuum \\
\hline ARB-B1-Z027 & 41 & 1 & 950 & 1 & flowing $\mathrm{He}$ & 20 & 1800 & 1 & vacuum \\
\hline ARB-B1-Z028 & 41 & 1 & 950 & 1 & flowing $\mathrm{He}$ & 20 & 1800 & 1 & vacuum \\
\hline ARB-B1-Z029 & 41 & 1 & 950 & 1 & flowing $\mathrm{He}$ & 20 & 1800 & 1 & vacuum \\
\hline ARB-B1-Z030 & 41 & 1 & 950 & 1 & flowing $\mathrm{He}$ & 20 & 1800 & 1 & vacuum \\
\hline ARB-B1-Z031 & 41 & 1 & 950 & 1 & flowing $\mathrm{He}$ & 20 & 1800 & 1 & vacuum \\
\hline ARB-B1-Z032 & 41 & 1 & 950 & 1 & flowing $\mathrm{He}$ & 20 & 1800 & 1 & vacuum \\
\hline ARB-B1-Z033 & 41 & 1 & 950 & 1 & flowing $\mathrm{He}$ & 20 & 1800 & 1 & vacuum \\
\hline ARB-B1-Z034 & 41 & 1 & 950 & 1 & flowing $\mathrm{He}$ & 20 & 1800 & 1 & vacuum \\
\hline ARB-B1-Z035 & 41 & 1 & 950 & 1 & flowing $\mathrm{He}$ & 20 & 1800 & 1 & vacuum \\
\hline ARB-B1-Z036 & 41 & 1 & 950 & 1 & flowing $\mathrm{He}$ & 20 & 1800 & 1 & vacuum \\
\hline ARB-B1-Z037 & 41 & 1 & 950 & 1 & flowing $\mathrm{He}$ & 20 & 1800 & 1 & vacuum \\
\hline ARB-B1-Z038 & 41 & 1 & 950 & 1 & flowing $\mathrm{He}$ & 20 & 1800 & 1 & vacuum \\
\hline ARB-B1-Z039 & 41 & 1 & 950 & 1 & flowing $\mathrm{He}$ & 20 & 1800 & 1 & vacuum \\
\hline ARB-B1-Z040 & 41 & 1 & 950 & 1 & flowing $\mathrm{He}$ & 20 & 1800 & 1 & vacuum \\
\hline ARB-B1-Z041 & 41 & 1 & 950 & 1 & flowing $\mathrm{He}$ & 20 & 1800 & 1 & vacuum \\
\hline ARB-B1-Z042 & 41 & 1 & 950 & 1 & flowing $\mathrm{He}$ & 20 & 1800 & 1 & vacuum \\
\hline ARB-B1-Z043 & 41 & 1 & 950 & 1 & flowing $\mathrm{He}$ & 20 & 1800 & 1 & vacuum \\
\hline ARB-B1-Z044 & 41 & 1 & 950 & 1 & flowing $\mathrm{He}$ & 20 & 1800 & 1 & vacuum \\
\hline ARB-B1-Z045 & 41 & 1 & 950 & 1 & flowing $\mathrm{He}$ & 20 & 1800 & 1 & vacuum \\
\hline ARB-B1-Z046 & 41 & 1 & 950 & 1 & flowing $\mathrm{He}$ & 20 & 1800 & 1 & vacuum \\
\hline ARB-B1-Z047 & 41 & 1 & 950 & 1 & flowing $\mathrm{He}$ & 20 & 1800 & 1 & vacuum \\
\hline ARB-B1-Z048 & 41 & 1 & 950 & 1 & flowing $\mathrm{He}$ & 20 & 1800 & 1 & vacuum \\
\hline ARB-B1-Z049 & 41 & 1 & 950 & 1 & flowing $\mathrm{He}$ & 20 & 1800 & 1 & vacuum \\
\hline ARB-B1-Z050 & 41 & 1 & 950 & 1 & flowing $\mathrm{He}$ & 20 & 1800 & 1 & vacuum \\
\hline
\end{tabular}

Task Manager Review Michal yamel

Date $8 / 15 / 11$

QAS Review

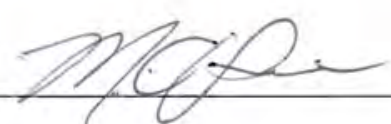

Date $\quad 8 / 6 / 11$ 


\section{Impurity Analysis of Matrix, Resin, and Graphite}

The AGR-3/4 Fuel Specification (SPC-1214, Rev. 1) specifies maximum limits on the elemental impurities $\mathrm{Al}, \mathrm{Ca}, \mathrm{Ti}+\mathrm{V}, \mathrm{Cr}, \mathrm{Mn}, \mathrm{Fe}, \mathrm{Co}, \mathrm{Ni}$, and $\mathrm{U}$. The natural graphite, synthetic graphite, and thermosetting resin used to make the matrix often contain measurable amounts of these impurities. It is beneficial if the graphite and resin have low concentrations of the impurities of interest to help ensure that the ring blanks made from the graphite/resin blend will be within specification. Although the graphite/resin blend used for the ARB-B1 ring blanks was not produced at ORNL, analysis was performed on the constituents used in that blend. Glow discharge mass spectrometry (GDMS) was performed by Shiva Technologies on samples of the natural and synthetic graphite. Samples of the Hexion SD-1708 resin, hexamethylenetetramine hardener, and graphite/resin Blend I were carbonized at $950^{\circ} \mathrm{C}$ under helium and the carbonized powder was also measured by GDMS.

Table 6 is a summary of the specified impurity levels for the natural graphite and synthetic graphite that were used to make the ARB-B1 ring blanks, as well as the impurity levels for carbonized samples of the resin, hardener, and final graphite/resin blend.

Table 6. Matrix constituents that were used in AGR-3/4 ARB-B1 ring blanks

\begin{tabular}{|c||c|c|c|c|c|c|}
\hline \multirow{2}{*}{ Element } & \multicolumn{7}{|c|}{ Impurity concentration (ppm-wt) } \\
\cline { 2 - 7 } & $\begin{array}{c}\text { SPC-1214 } \\
\text { Rev. 1 }\end{array}$ & $\begin{array}{c}\text { Natural Graphite } \\
\text { Asbury 3482 }\end{array}$ & $\begin{array}{c}\text { Synthetic Graphite } \\
\text { SGL KRB2000 }\end{array}$ & $\begin{array}{c}\text { Carbonized Resin } \\
\text { Hexion SD-1708 }\end{array}$ & $\begin{array}{c}\text { Carbonized } \\
\text { Hexa }\end{array}$ & $\begin{array}{c}\text { Carbonized } \\
\text { Blend I }\end{array}$ \\
\hline \hline $\mathrm{Al}$ & $\leq 20$ & 29 & 0.13 & 8 & 16 & 28 \\
\hline $\mathrm{Ca}$ & $\leq 45$ & 8.2 & 0.31 & 4.2 & 33 & 12 \\
\hline $\mathrm{Ti}+\mathrm{V}$ & $\leq 85$ & 2.75 & $<0.07$ & 0.32 & 5.34 & 1.35 \\
\hline $\mathrm{Cr}$ & $\leq 10$ & $<0.5$ & $<0.5$ & 3.9 & $<0.5$ & $<0.5$ \\
\hline $\mathrm{Mn}$ & $\leq 10$ & 0.55 & $<0.05$ & 0.34 & 0.55 & 0.74 \\
\hline $\mathrm{Fe}$ & $\leq 20$ & 38 & 0.11 & 18 & 39 & 45 \\
\hline $\mathrm{Co}$ & $\leq 10$ & $<0.05$ & $<0.05$ & 1.6 & $<0.05$ & $<0.05$ \\
\hline $\mathrm{Ni}$ & $\leq 10$ & 0.25 & 0.12 & 2.9 & 1.7 & 1 \\
\hline $\mathrm{U}$ & $\leq 0.5$ & $<0.05$ & $<0.05$ & $<0.05$ & $<0.05$ & $<0.05$ \\
\hline
\end{tabular}

The following pages show the full impurity analysis reports for the natural graphite, synthetic graphite, resin, hexamethylenetetramine, and Blend I samples listed in Table 6. Impurities that could not be detected above the analysis threshold value are reported as less than values $(<)$. Values marked as less than or equal to $(=<)$ indicate that a measurable value of the element was obtained, but that this element may have come from the Shiva sample preparation. Prior to GDMS analysis, Shiva poured the powder samples into a Teflon mold with a binder material. The binder was mostly indium, but may also have contained other elements, as indicated in the analysis report by the "=<" symbol. The resin showed very high values for F, but these were marked as semiquantitative $(\sim)$ and probably came from the Teflon mold. The natural graphite and graphite/resin blend were very high in $\mathrm{Si}$ and also high in $\mathrm{Mg}, \mathrm{Al}, \mathrm{S}$, and $\mathrm{Fe}$. The hexamethylenetetramine was high in several impurities, but is less critical because it only makes up $1 \%$ of the graphite/resin blend. 
GDMS

ANALYTICAL REPORT
SHIVA Technologies

An Operating Unit of Evans Analytical Group LLC

6707 Brooklawn Parkway

Syracuse, New York 13211
Telephone [315] 431-9900

Fax: [315] 431-9800

Email infony@eaglabs.com www.eaglabs.com
Customer: UT-Battelle Oak Ridge
P.O.\#
4000100480
Date:
1 Bethel Valley Rd, Oak Ridge, TN 37823-6063 USA
Customer ID: C
Job \#
SOABV776
6-Nov-10
Sample ID:
S101101057

\section{Asbury 3482 NFG}

\begin{tabular}{|c|c|c|c|}
\hline Element & $\begin{array}{c}\text { Concentration } \\
{[\text { ppm wt ] }}\end{array}$ & Element & $\begin{array}{l}\text { Concentration } \\
\text { [ppm wt ] }\end{array}$ \\
\hline $\mathrm{Li}$ & $<0.01$ & $\mathrm{Pd}$ & $<0.1$ \\
\hline $\mathrm{Be}$ & $<0.01$ & $\mathrm{Ag}$ & $<0.1$ \\
\hline$B$ & 0.24 & $\mathrm{Cd}$ & $<0.1$ \\
\hline C & Matrix & $\ln$ & Binder \\
\hline $\mathrm{N}$ & - & Sn & $<0.5$ \\
\hline $\mathrm{O}$ & - & $\mathrm{Sb}$ & $<0.5$ \\
\hline $\mathrm{F}$ & $\sim 20$ & $\mathrm{Te}$ & $<0.1$ \\
\hline $\mathrm{Na}$ & 1.5 & I & $<20$ \\
\hline $\mathrm{Mg}$ & 80 & Cs & $<0.1$ \\
\hline $\mathrm{Al}$ & 29 & $\mathrm{Ba}$ & 0.8 \\
\hline $\mathrm{Si}$ & 710 & $\mathrm{La}$ & $<0.5$ \\
\hline$P$ & 0.82 & $\mathrm{Ce}$ & $<0.5$ \\
\hline$S$ & 25 & $\mathrm{Pr}$ & $<0.05$ \\
\hline $\mathrm{Cl}$ & 2.5 & $\mathrm{Nd}$ & $<0.05$ \\
\hline $\mathrm{K}$ & 0.2 & Sm & $<0.05$ \\
\hline $\mathrm{Ca}$ & 8.2 & $\mathrm{Eu}$ & $<0.05$ \\
\hline Sc & $<0.05$ & $\mathrm{Gd}$ & $<0.05$ \\
\hline $\mathrm{Ti}$ & 2.3 & $\mathrm{~Tb}$ & $<0.05$ \\
\hline $\mathrm{V}$ & 0.45 & Dy & $<0.05$ \\
\hline $\mathrm{Cr}$ & $<0.5$ & Ho & $<0.05$ \\
\hline $\mathrm{Mn}$ & 0.55 & $\mathrm{Er}$ & $<0.05$ \\
\hline $\mathrm{Fe}$ & 38 & $\mathrm{Tm}$ & $<0.05$ \\
\hline Co & $<0.05$ & $\mathrm{Yb}$ & $<0.05$ \\
\hline $\mathrm{Ni}$ & 0.25 & $\mathrm{Lu}$ & $<0.05$ \\
\hline $\mathrm{Cu}$ & 2.5 & $\mathrm{Hf}$ & $<0.05$ \\
\hline $\mathrm{Zn}$ & 0.4 & $\mathrm{Ta}$ & $<5$ \\
\hline $\mathrm{Ga}$ & $<0.1$ & W & 0.15 \\
\hline $\mathrm{Ge}$ & $<0.1$ & $\mathrm{Re}$ & $<0.05$ \\
\hline As & $<0.1$ & Os & $<0.05$ \\
\hline $\mathrm{Se}$ & $<0.1$ & $\mathrm{Ir}$ & $<0.05$ \\
\hline $\mathrm{Br}$ & 0.41 & $\mathrm{Pt}$ & $<0.05$ \\
\hline $\mathrm{Rb}$ & $<0.05$ & $\mathrm{Au}$ & $<0.1$ \\
\hline $\mathrm{Sr}$ & 0.08 & $\mathrm{Hg}$ & $<0.5$ \\
\hline $\mathrm{Y}$ & 0.2 & $\mathrm{Tl}$ & $<0.1$ \\
\hline $\mathrm{Zr}$ & 0.6 & $\mathrm{~Pb}$ & $<0.5$ \\
\hline $\mathrm{Nb}$ & $<0.1$ & $\mathrm{Bi}$ & $<0.1$ \\
\hline Mo & $<0.05$ & Th & $<0.05$ \\
\hline $\mathrm{Ru}$ & $<0.1$ & $\mathrm{U}$ & $<0.05$ \\
\hline $\mathrm{Rh}$ & $<0.1$ & & \\
\hline
\end{tabular}

$\sim$ Semiquantitative Values

Page 1 of 1 - GDMS

J.SCHIEBLER (Analyst)

Reviewed by

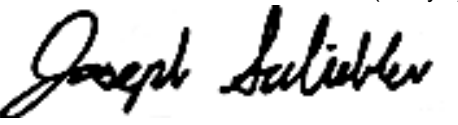




$\begin{array}{llll}\text { Customer: } & \text { UT-Battelle Oak Ridge } & \text { P.O.\# } & \text { CC } \\ & \text { 1 Bethel Valley Rd, Oak Ridge, TN 37823-6063 USA } & & \\ \text { Date: } & \text { 24-Mar-11 } & \text { Job \# } & \text { S0BCT802 } \\ \text { Customer ID: } \text { C powder } & \text { SRB } 2000 & & \text { S110317087 } \\ & \text { KRB }: & \end{array}$

\begin{tabular}{|c|c|c|c|}
\hline Element & $\begin{array}{c}\text { Concentration } \\
\text { [ ppm wt ] }\end{array}$ & Element & $\begin{array}{c}\text { Concentration } \\
\text { [ppm wt ] }\end{array}$ \\
\hline $\mathrm{Li}$ & $<0.01$ & $\mathrm{Pd}$ & $<0.1$ \\
\hline $\mathrm{Be}$ & $<0.01$ & $\mathrm{Ag}$ & $<0.1$ \\
\hline $\mathrm{B}$ & 0.19 & $\mathrm{Cd}$ & $<0.1$ \\
\hline C & Matrix & $\ln$ & Binder \\
\hline $\mathrm{N}$ & - & Sn & $<0.5$ \\
\hline $\mathrm{O}$ & - & $\mathrm{Sb}$ & $<0.5$ \\
\hline $\mathrm{F}$ & $=<10$ & $\mathrm{Te}$ & $<0.1$ \\
\hline $\mathrm{Na}$ & 0.92 & 1 & $<20$ \\
\hline $\mathrm{Mg}$ & $<0.5$ & Cs & $<0.1$ \\
\hline $\mathrm{Al}$ & 0.13 & $\mathrm{Ba}$ & $<0.1$ \\
\hline Si & 3.1 & $\mathrm{La}$ & $<0.5$ \\
\hline $\mathrm{P}$ & $<0.1$ & $\mathrm{Ce}$ & $<0.5$ \\
\hline$S$ & 5.4 & $\mathrm{Pr}$ & $<0.05$ \\
\hline $\mathrm{Cl}$ & 9.3 & $\mathrm{Nd}$ & $<0.05$ \\
\hline $\mathrm{K}$ & $<0.1$ & $\mathrm{Sm}$ & $<0.05$ \\
\hline $\mathrm{Ca}$ & 0.31 & $\mathrm{Eu}$ & $<0.05$ \\
\hline$\overline{S c}$ & $<0.05$ & $\mathrm{Gd}$ & $<0.05$ \\
\hline $\mathrm{Ti}$ & 0.06 & $\mathrm{~Tb}$ & $<0.05$ \\
\hline $\mathrm{V}$ & $<0.01$ & Dy & $<0.05$ \\
\hline $\mathrm{Cr}$ & $<0.5$ & $\mathrm{Ho}$ & $<0.05$ \\
\hline $\mathrm{Mn}$ & $<0.05$ & $\mathrm{Er}$ & $<0.05$ \\
\hline $\mathrm{Fe}$ & 0.11 & $\mathrm{Tm}$ & $<0.05$ \\
\hline Co & $<0.05$ & $\mathrm{Yb}$ & $<0.05$ \\
\hline $\mathrm{Ni}$ & 0.12 & $\mathrm{Lu}$ & $<0.05$ \\
\hline $\mathrm{Cu}$ & $<0.1$ & $\mathrm{Hf}$ & $<0.05$ \\
\hline$\overline{Z n}$ & $<0.1$ & $\mathrm{Ta}$ & $<5$ \\
\hline $\mathrm{Ga}$ & $<0.1$ & W & 0.09 \\
\hline $\mathrm{Ge}$ & $<0.1$ & $\mathrm{Re}$ & $<0.05$ \\
\hline As & $<0.1$ & Os & $<0.05$ \\
\hline $\mathrm{Se}$ & $<0.1$ & $\mathrm{Ir}$ & $<0.05$ \\
\hline $\mathrm{Br}$ & $<0.1$ & $\mathrm{Pt}$ & $<0.05$ \\
\hline $\mathrm{Rb}$ & $<0.05$ & $\mathrm{Au}$ & $<0.1$ \\
\hline $\mathrm{Sr}$ & $<0.05$ & $\mathrm{Hg}$ & $<0.5$ \\
\hline $\bar{Y}$ & $<0.05$ & $\mathrm{TI}$ & $<0.1$ \\
\hline $\mathrm{Zr}$ & $<0.05$ & $\mathrm{~Pb}$ & $<0.5$ \\
\hline $\mathrm{Nb}$ & $<0.1$ & $\mathrm{Bi}$ & $<0.1$ \\
\hline Mo & $<0.05$ & Th & $<0.05$ \\
\hline $\mathrm{Ru}$ & $<0.1$ & $\mathrm{U}$ & $<0.05$ \\
\hline $\mathrm{Rh}$ & $<0.1$ & & \\
\hline
\end{tabular}

$\sim$ Semiquantitative Values 
GDMS

ANALYTICAL REPORT
SHIVA Technologies

An Operating Unit of Evans Analytical Group LLC

6707 Brooklawn Parkway

Syracuse, New York 13211
Telephone [315] 431-9900

Fax: [315] 431-9800

Email infony@eaglabs.com www.eaglabs.com
Customer: UT-Battelle Oak Ridge
P.O.\#
4000100480
Date:
1 Bethel Valley
Job \#
SOABV776
Customer ID: C
Sample ID:
S101101061

\section{Hexion SD-1708}

\begin{tabular}{|c|c|c|c|}
\hline Element & $\begin{array}{c}\text { Concentration } \\
{[\text { ppm wt ] }}\end{array}$ & Element & $\begin{array}{l}\text { Concentration } \\
\text { [ppm wt ] }\end{array}$ \\
\hline $\mathrm{Li}$ & 0.5 & $\mathrm{Pd}$ & $<0.1$ \\
\hline $\mathrm{Be}$ & $<0.01$ & $\mathrm{Ag}$ & $<0.1$ \\
\hline$B$ & 0.06 & $\mathrm{Cd}$ & $<0.1$ \\
\hline C & Matrix & $\ln$ & Binder \\
\hline $\mathrm{N}$ & - & Sn & $<0.5$ \\
\hline 0 & - & $\mathrm{Sb}$ & $<0.5$ \\
\hline $\mathrm{F}$ & $\sim 560$ & $\mathrm{Te}$ & $<0.1$ \\
\hline $\mathrm{Na}$ & 5.4 & I & $=<60$ \\
\hline $\mathrm{Mg}$ & $<0.5$ & $\mathrm{Cs}$ & $<0.1$ \\
\hline $\mathrm{Al}$ & 8 & $\mathrm{Ba}$ & $<0.1$ \\
\hline $\mathrm{Si}$ & 18 & $\mathrm{La}$ & $=<6$ \\
\hline$P$ & 0.25 & $\mathrm{Ce}$ & $<0.5$ \\
\hline$S$ & 3.5 & $\mathrm{Pr}$ & $=<1.5$ \\
\hline $\mathrm{Cl}$ & 0.79 & $\mathrm{Nd}$ & $<0.05$ \\
\hline $\mathrm{K}$ & 0.2 & Sm & $<0.05$ \\
\hline $\mathrm{Ca}$ & 4.2 & Eu & $<0.05$ \\
\hline Sc & $<0.05$ & $\mathrm{Gd}$ & $<0.05$ \\
\hline $\mathrm{Ti}$ & 0.3 & $\mathrm{~Tb}$ & $<0.05$ \\
\hline $\mathrm{V}$ & 0.02 & Dy & $<0.05$ \\
\hline $\mathrm{Cr}$ & 3.9 & Ho & $<0.05$ \\
\hline $\mathrm{Mn}$ & 0.34 & $\mathrm{Er}$ & $<0.05$ \\
\hline $\mathrm{Fe}$ & 18 & $\mathrm{Tm}$ & $<0.05$ \\
\hline Co & 1.6 & $\mathrm{Yb}$ & $<0.05$ \\
\hline $\mathrm{Ni}$ & 2.9 & $\mathrm{Lu}$ & $<0.05$ \\
\hline $\mathrm{Cu}$ & 21 & $\mathrm{Hf}$ & $<0.05$ \\
\hline $\mathrm{Zn}$ & $=<2$ & $\mathrm{Ta}$ & $<5$ \\
\hline $\mathrm{Ga}$ & $<0.1$ & W & 0.08 \\
\hline $\mathrm{Ge}$ & $<0.1$ & $\mathrm{Re}$ & $<0.05$ \\
\hline As & $<0.1$ & Os & $<0.05$ \\
\hline $\mathrm{Se}$ & $<0.1$ & $\mathrm{Ir}$ & $<0.05$ \\
\hline $\mathrm{Br}$ & $<0.1$ & $\mathrm{Pt}$ & $<0.05$ \\
\hline $\mathrm{Rb}$ & $<0.05$ & $\mathrm{Au}$ & $<0.1$ \\
\hline $\mathrm{Sr}$ & $<0.05$ & $\mathrm{Hg}$ & $<0.5$ \\
\hline $\mathrm{Y}$ & 0.68 & $\mathrm{Tl}$ & $<0.1$ \\
\hline $\mathrm{Zr}$ & $<0.05$ & $\mathrm{~Pb}$ & $<0.5$ \\
\hline $\mathrm{Nb}$ & $<0.1$ & $\mathrm{Bi}$ & $<0.1$ \\
\hline Mo & 0.64 & Th & $<0.05$ \\
\hline $\mathrm{Ru}$ & $<0.1$ & $\mathrm{U}$ & $<0.05$ \\
\hline $\mathrm{Rh}$ & $<0.1$ & & \\
\hline
\end{tabular}

$\sim$ Semiquantitative Values

Page 1 of 1 - GDMS

Reviewed by 
GDMS

ANALYTICAL REPORT
SHIVA Technologies

An Operating Unit of Evans Analytical Group LLC

6707 Brooklawn Parkway

Syracuse, New York 13211
Telephone [315] 431-9900

Fax: [315] 431-9800

Email infony@eaglabs.com www.eaglabs.com

$\begin{array}{llll}\text { Customer: } & \text { UT-Battelle Oak Ridge } & \text { P.O.\# } & \mathbf{4 0 0 0 1 0 0 4 8 0} \\ & \text { 1 Bethel Valley Rd, Oak Ridge, TN 37823-6063 USA } & & \\ \text { Date: } & \text { 6-Nov-10 } & \text { Job \# } & \text { S0ABV776 } \\ \text { Customer ID: } \mathbf{C} & \text { Sample ID: } & \text { S101101062 }\end{array}$

\section{Hexa}

\begin{tabular}{|c|c|c|c|}
\hline Element & $\begin{array}{l}\text { Concentration } \\
\text { [ ppm wt ] }\end{array}$ & Element & $\begin{array}{c}\text { Concentration } \\
\text { [ ppm wt ] }\end{array}$ \\
\hline $\mathrm{Li}$ & 6.4 & $\mathrm{Pd}$ & $<0.1$ \\
\hline$\overline{\mathrm{Be}}$ & $<0.01$ & $\mathrm{Ag}$ & 3.9 \\
\hline$B$ & 2.5 & $\mathrm{Cd}$ & $<0.1$ \\
\hline $\mathrm{C}$ & Matrix & $\ln$ & Binder \\
\hline $\bar{N}$ & - & $\mathrm{Sn}$ & $<0.5$ \\
\hline $\mathrm{O}$ & - & $\mathrm{Sb}$ & $<0.5$ \\
\hline $\mathrm{F}$ & $\sim 960$ & $\mathrm{Te}$ & $<0.1$ \\
\hline $\mathrm{Na}$ & 220 & $\mathrm{I}$ & $=<550$ \\
\hline $\mathrm{Mg}$ & 28 & $\mathrm{Cs}$ & $<0.1$ \\
\hline $\mathrm{Al}$ & 16 & $\mathrm{Ba}$ & $<0.1$ \\
\hline $\mathrm{Si}$ & 130 & $\mathrm{La}$ & $=<26$ \\
\hline $\mathrm{P}$ & 4.8 & $\mathrm{Ce}$ & $=<1.2$ \\
\hline S & 44 & $\mathrm{Pr}$ & $=<2.8$ \\
\hline $\mathrm{Cl}$ & 3.8 & $\mathrm{Nd}$ & $<0.05$ \\
\hline $\mathrm{K}$ & 5.4 & $\mathrm{Sm}$ & $<0.05$ \\
\hline $\mathrm{Ca}$ & 33 & Eu & $<0.05$ \\
\hline $\mathrm{Sc}$ & $<0.05$ & $\mathrm{Gd}$ & $<0.05$ \\
\hline $\mathrm{Ti}$ & 5.3 & $\mathrm{~Tb}$ & $<0.05$ \\
\hline $\bar{V}$ & 0.04 & Dy & $<0.05$ \\
\hline $\mathrm{Cr}$ & $<0.5$ & $\mathrm{Ho}$ & $<0.05$ \\
\hline $\mathrm{Mn}$ & 0.55 & $\mathrm{Er}$ & $<0.05$ \\
\hline $\mathrm{Fe}$ & 39 & $\mathrm{Tm}$ & $<0.05$ \\
\hline $\mathrm{Co}$ & $<0.05$ & $\mathrm{Yb}$ & $<0.05$ \\
\hline $\mathrm{Ni}$ & 1.7 & $L u$ & $<0.05$ \\
\hline $\mathrm{Cu}$ & 42 & $\mathrm{Hf}$ & $<0.05$ \\
\hline $\mathrm{Zn}$ & 220 & $\mathrm{Ta}$ & $<5$ \\
\hline $\mathrm{Ga}$ & $<0.1$ & $\mathrm{~W}$ & 1.2 \\
\hline $\mathrm{Ge}$ & $<0.1$ & $\mathrm{Re}$ & $<0.05$ \\
\hline As & 0.29 & Os & $<0.05$ \\
\hline $\mathrm{Se}$ & $<0.1$ & $\mathrm{Ir}$ & $<0.05$ \\
\hline $\mathrm{Br}$ & $<0.1$ & $\mathrm{Pt}$ & $<0.05$ \\
\hline $\mathrm{Rb}$ & $<0.05$ & $\mathrm{Au}$ & $<0.1$ \\
\hline $\mathrm{Sr}$ & 0.16 & $\mathrm{Hg}$ & $<0.5$ \\
\hline $\bar{Y}$ & $<0.05$ & $\mathrm{TI}$ & $<0.1$ \\
\hline $\mathrm{Zr}$ & $<0.05$ & $\mathrm{~Pb}$ & $<0.5$ \\
\hline $\mathrm{Nb}$ & $<0.1$ & $\mathrm{Bi}$ & $<0.1$ \\
\hline Mo & 1.5 & Th & $<0.05$ \\
\hline $\mathrm{Ru}$ & $<0.1$ & $\mathrm{U}$ & $<0.05$ \\
\hline $\mathrm{Rh}$ & $<0.1$ & & \\
\hline
\end{tabular}

$\sim$ Semiquantitative Values

Page 1 of 1 - GDMS

Reviewed by

J.SCHIEBLER (Analyst)

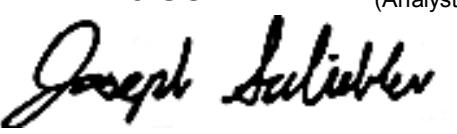


Customer: UT-Battelle Oak Ridge

Date:

Customer ID: C powder

1 Bethel Valley Rd, Oak Ridge, TN 37823-6063 USA

18-Aug-11

INL Blend I
P.O.\#

Job \#

Sample ID:
CC

SOBDV257

S110818033

Element Concentration Element Concentration

\begin{tabular}{|c|c|c|c|}
\hline & $\mathrm{ppm} w \mathrm{wt}$ & & {$[\mathrm{ppm} w \mathrm{wt}$} \\
\hline $\mathrm{Li}$ & 0.55 & $\mathrm{Pd}$ & $<0.1$ \\
\hline $\mathrm{Be}$ & $<0.01$ & $\mathrm{Ag}$ & $<0.1$ \\
\hline$B$ & 0.6 & $\mathrm{Cd}$ & $<0.1$ \\
\hline $\mathrm{C}$ & Matrix & $\ln$ & Binder \\
\hline $\mathrm{N}$ & - & Sn & $<0.5$ \\
\hline 0 & - & $\mathrm{Sb}$ & $<0.5$ \\
\hline$F$ & $=<50$ & $\mathrm{Te}$ & $<0.1$ \\
\hline $\mathrm{Na}$ & 5.5 & 1 & $<20$ \\
\hline $\mathrm{Mg}$ & 53 & Cs & $<0.1$ \\
\hline $\mathrm{Al}$ & 28 & $\mathrm{Ba}$ & 1.8 \\
\hline $\mathrm{Si}$ & 400 & $\mathrm{La}$ & $<0.5$ \\
\hline$P$ & 0.95 & $\mathrm{Ce}$ & $<0.5$ \\
\hline $\mathrm{S}$ & 20 & $\mathrm{Pr}$ & $<0.05$ \\
\hline $\mathrm{Cl}$ & 1.9 & $\mathrm{Nd}$ & $<0.05$ \\
\hline $\mathrm{K}$ & 0.5 & $\mathrm{Sm}$ & $<0.05$ \\
\hline $\mathrm{Ca}$ & 12 & $\mathrm{Eu}$ & $<0.05$ \\
\hline Sc & $<0.05$ & $\mathrm{Gd}$ & $<0.05$ \\
\hline $\mathrm{Ti}$ & 0.9 & $\mathrm{~Tb}$ & $<0.05$ \\
\hline $\mathrm{V}$ & 0.45 & Dy & $<0.05$ \\
\hline $\mathrm{Cr}$ & $<0.5$ & $\mathrm{Ho}$ & $<0.05$ \\
\hline $\mathrm{Mn}$ & 0.74 & $\mathrm{Er}$ & $<0.05$ \\
\hline $\mathrm{Fe}$ & 45 & $\mathrm{Tm}$ & $<0.05$ \\
\hline Co & $<0.05$ & $\mathrm{Yb}$ & $<0.05$ \\
\hline $\mathrm{Ni}$ & 1 & $\mathrm{Lu}$ & $<0.05$ \\
\hline $\mathrm{Cu}$ & $<0.1$ & $\mathrm{Hf}$ & $<0.05$ \\
\hline $\mathrm{Zn}$ & $<0.1$ & $\mathrm{Ta}$ & $<5$ \\
\hline $\mathrm{Ga}$ & $<0.1$ & W & 0.22 \\
\hline $\mathrm{Ge}$ & $<0.1$ & $\operatorname{Re}$ & $<0.05$ \\
\hline As & $<0.1$ & Os & $<0.05$ \\
\hline $\mathrm{Se}$ & $<0.1$ & $\mathrm{Ir}$ & $<0.05$ \\
\hline $\mathrm{Br}$ & 2.2 & $\mathrm{Pt}$ & $<0.05$ \\
\hline $\mathrm{Rb}$ & $<0.05$ & $\mathrm{Au}$ & $<0.1$ \\
\hline $\mathrm{Sr}$ & 0.13 & $\mathrm{Hg}$ & $<0.5$ \\
\hline $\mathrm{Y}$ & 0.15 & $\mathrm{TI}$ & $<0.1$ \\
\hline$Z r$ & 1.2 & $\mathrm{~Pb}$ & $<0.5$ \\
\hline $\mathrm{Nb}$ & $<0.1$ & $\mathrm{Bi}$ & $<0.1$ \\
\hline Mo & 0.4 & Th & $<0.05$ \\
\hline $\mathrm{Ru}$ & $<0.1$ & $U$ & $<0.05$ \\
\hline $\mathrm{Rh}$ & $<0.1$ & & \\
\hline
\end{tabular}

Page 1 of 1 - GDMS

Reviewed by

J.SCHIEBLER (Analyst)

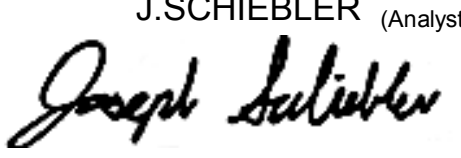




\section{Characterization of ARB-B1 Ring Blanks}

Ring blanks were characterized for product acceptance according to AGR-CHAR-PIP-20R1, "Product Inspection Plan for AGR-3/4 Ring Blank Lots." This plan calls for measurement of ring blank length, diameter, mass, matrix density, and impurity content. Length, diameter, and matrix density were measured on every ring blank. Maximum length was measured using a digital height gauge and the diameter at the midpoint was measured using a digital caliper. Average matrix density was calculated by weighing the ring blank and dividing the mass by the calculated volume with the assumption of cylindrical shape. It is known that local matrix density varies along the length of the cylinder due to the use of a single acting cylindrical die. When RDKRS ring blanks were sectioned perpendicular to the cylinder axis and average density of each section measured separately, a systematic decrease in the density was observed from the end facing the moving ram to the end facing the fixed ram.

Twelve ring blanks were selected for analysis of uranium and other specified impurities $(\mathrm{Fe}, \mathrm{Cr}$, $\mathrm{Mn}, \mathrm{Co}, \mathrm{Ni}, \mathrm{Ca}, \mathrm{Al}$, and $\mathrm{Ti}+\mathrm{V}$ ). Analysis was performed on the 12 ring blanks, in four sample groups with 3 ring blanks in each sample group. Ring blanks were burned in air to reduce them to oxide ash. The ash was leached with boiling nitric acid for 24 hours, followed by a second 24 hour boiling nitric acid leach. Aliquots of each leach solution were analyzed by inductivelycoupled plasma mass spectrometry (ICP-MS). After the standard burn-leach analysis, $159 \mathrm{mg}$ to $171 \mathrm{mg}$ of ash residue remained. This ash residue was further analyzed by microwave-enhanced acid digestion and ICP-MS. After the microwave digestion, 116 - $128 \mathrm{mg}$ residue remained. This was not analyzed further. Previous analysis was similarly applied to the RDKRS ring blanks (see Section 6 of ORNL/TM-2011/127). There was less residual ash after burn-leach of the RDKRS ring blanks $(63-66 \mathrm{mg})$. Most of the RDKRS residual ash was dissolved by the microwave digestion. It is possible that the greater amount of residual ash from the ARB-B1 ring blanks was more than could be digested in one pass. The difference in ash content was mostly related to the difference in the silicon content in the natural graphite. There was $710 \mathrm{ppmw}$ of Si in the Asbury 3482 natural graphite used for the ARB-B1 ring blanks. The Asbury RD-13371 natural graphite used for the RDKRS ring blanks contained 260 ppmw Si. The Asbury 3482 was also about 3x higher in $\mathrm{Al}, \mathrm{Ti}$, and $\mathrm{Fe}$.

At the end of this section are copies of the inspection report forms (IRF) for the ARB-B1 ring blanks (IRF-20A, IRF-20B, IRF-20B-Supplemental and IRF-20C). Following the inspection report forms are the individual data report forms (DRF) for the measurements that were performed. Inspection report form IRF-20B summarizes the burn-leach results. However, because of the amount of residual ash remaining after the standard burn-leach analysis, results of from microwave digestion were included in the acceptance testing. Inspection report form IRF20B-Supplemental adds the results of the microwave digestion to the burn-leach results and these totals are used for the calculation for product acceptance on inspection report form IRF-20A The acceptance test values on IRF-20A were calculated using a 95\% confidence Student's-t test.

The overall average diameter, length, and matrix density for the ring blank lot are reported on IRF-20A, but the product compliance to these specified parameters was determined on an individual basis for each ring blank (see DRF-43). As discussed in section 2, nineteen of the ring blanks had an average density above the specified limit of $1.80 \mathrm{~g} / \mathrm{cm}^{3}$. These are indicated by 
"fail" in the rightmost column of DRF43. The disposition of these non-conforming ring blanks for use as samples for the impurity analysis or retention as ORNL archives was documented on NCR-X-AGR-11-01 (see Appendix A). All the ring blanks shipped to INL for possible use in the AGR-3/4 irradiation test were within the specified range for mean diameter, length, and matrix density. Table 7 provides a summary of these properties for the 30 ring blanks shipped to INL for possible use in the AGR-3/4 irradiation test.

Table 7. Average ring blank dimensions and density for 30 shipped to INL

\begin{tabular}{|c|c|c|c|}
\hline \multirow{2}{*}{\multicolumn{2}{|c|}{ Specified Parameters }} & \multicolumn{2}{|c|}{30 ARB-B1 ring blanks sent to INL } \\
\hline & & mean & standard deviation \\
\hline Blank outer diameter $(\mathrm{mm})$ & $26.0 \pm 1$ & 25.70 & 0.06 \\
\hline Blank length $(\mathrm{mm})$ & $63.0 \pm 2$ & 62.3 & 0.5 \\
\hline Blank matrix density $(\mathrm{g} / \mathrm{cc})$ & $1.65 \pm 0.15$ & 1.770 & 0.019 \\
\hline
\end{tabular}

As expected based on the higher impurity content of the ARB-B1 graphite/resin matrix blend, compared to the RDKRS blend, impurity content in the ARB-B1 ring blanks was higher than that previously reported for the RDKRS ring blank set (ORNL/TM-2011/127). Of particular note were the Fe and Al content (Table 8). These values were higher than expected based on the difference in the impurity content between the two graphite/resin blends (Table 9). For both materials, iron content was reduced by the heat-treatment of the ring blanks, but the percent reduction in the ARB-B1 ring blanks was an order of magnitude lower. Aluminum content was not reduced by the heat-treatment as efficiently as the Fe content in either material, but for the ARB-B1 ring blanks the reduction was almost negligible. The average matrix density of the ARB-B1 ring blanks was 10\% higher than the RDKRS ring blanks, but this does not seem like a large enough difference to completely explain the difference in the effectiveness of the heattreatment. Qualitatively, the ARB-B1 ring blanks appeared more solid. It may be that the permeability of these ring blanks is lower due to the difference in the resins and/or the size of the graphite flake. It is also possible that the additional silicon in the ARB-B1 ring blanks may have bound up some of the other impurities.

Table 8. Comparison of impurity content between RDKRS and ARB-B1 ring blanks

\begin{tabular}{|c|c|c|c|c|}
\hline \multirow{2}{*}{ Impurity Content Specification } & \multicolumn{2}{|c|}{ Mean Content (ppmw) } & \multirow{2}{*}{ ARB-B1 / RDKRS } \\
\cline { 3 - 4 } & & RDKRS & ARB-B1 & \\
\hline $\mathrm{Fe}$ & $\leq 20$ & $<0.07$ & 2.90 & 41 \\
\hline $\mathrm{Cr}$ & $\leq 10$ & $<0.0035$ & 0.050 & 14 \\
\hline $\mathrm{Mn}$ & $\leq 10$ & $<0.0013$ & $<0.0011$ & 0.8 \\
\hline $\mathrm{Co}$ & $\leq 10$ & $<0.0009$ & $<0.0038$ & 4 \\
\hline $\mathrm{Ni}$ & $\leq 10$ & $<0.0051$ & $<0.0328$ & 6 \\
\hline $\mathrm{Ca}$ & $\leq 45$ & 3.9 & 7.29 & 2 \\
\hline $\mathrm{Al}$ & $\leq 20$ & 1.33 & 24.6 & 18 \\
\hline $\mathrm{Ti}+\mathrm{V}$ & $\leq 85$ & 2.06 & 3.98 & 2 \\
\hline $\mathrm{U}$ & $\leq 0.5$ & 0.017 & 0.1 (note 1$)$ & 6 \\
\hline
\end{tabular}

note 1: mean $U$ content does not include abnormal result from one sample group 
Table 9. Comparison of impurity content between RDKRS and ARB-B1 graphite/resin blends after carbonization

\begin{tabular}{|c|c|c|c|c|}
\hline \multirow{2}{*}{ Impurity Content Specification } & \multicolumn{2}{|c|}{ Mean Content (ppmw) } & \multirow{2}{*}{ ARB-B1 / RDKRS } \\
\cline { 3 - 5 } & & RDKRS & ARB-B1 & \\
\hline $\mathrm{Fe}$ & $\leq 20$ & 12 & 45 & 4 \\
\hline $\mathrm{Cr}$ & $\leq 10$ & $<0.5$ & $<0.5$ & 2 \\
\hline $\mathrm{Mn}$ & $\leq 10$ & 0.35 & 0.74 & 1 \\
\hline $\mathrm{Co}$ & $\leq 10$ & $<0.05$ & $<0.05$ & 6 \\
\hline $\mathrm{Ni}$ & $\leq 10$ & 0.18 & 1 & 2.5 \\
\hline $\mathrm{Ca}$ & $\leq 45$ & 4.8 & 12 & 6.5 \\
\hline $\mathrm{Al}$ & $\leq 20$ & 4.3 & 28 & 5 \\
\hline $\mathrm{Ti}+\mathrm{V}$ & $\leq 85$ & 0.29 & 1.35 & 1 \\
\hline $\mathrm{U}$ & $\leq 0.5$ & $<0.05$ & $<0.05$ & \\
\hline
\end{tabular}

As a result of the higher initial Al impurity content and the negligible loss of Al during heattreatment, the average Al impurity content was slightly above the specified limit. The specified limit for aluminum is a conservative value and the measured impurity content is not expected to adversely affect the AGR-3/4 irradiation experiment. This non-conformance was documented on NCR-X-AGR-11-02 (see Appendix B) with a disposition to use the ring blanks as they are.

In addition to a non-conforming aluminum content, burn-leach and microwave digestion analysis also yielded a uranium content that was beyond the specified limit of $\leq 0.5 \mathrm{ppmw}$. Of the four sample groups analyzed (ARB-B1-Z035, -Z027, -Z040), one was determined to have an unusually high amount of uranium (1.95 ppmw). The average uranium content of the other three sample groups was $0.10 \mathrm{ppmw}$ with a standard deviation of $0.03 \mathrm{ppmw}$. The data from these three groups would satisfy the specification, with a 95\% confidence test value of $0.15 \mathrm{ppmw}$. However, the average for all four sample groups was $0.6 \mathrm{ppmw}$, which was above the specified limit. This non-conformance was documented on NCR-X-AGR-11-03 (see Appendix C). The discussion attached to this non-conformance report describes the issue in more detail. Additional characterization was performed, but no definitive data was available to determine the exact cause of the unusually high uranium contamination. The additional analysis described in Appendix $\mathrm{C}$ suggested that this was an abnormal and possibly isolated occurrence and the disposition for the non-conformance was to use the ARB-B1 ring blank set as they are.

Also discussed in the analysis of the uranium contamination in Appendix $\mathrm{C}$ is the observation of general contamination with natural uranium (NU) and low enriched uranium (LEU). Analysis of the uranium contamination suggested that there was a quantity of natural uranium that probably came from the natural graphite used to make the graphite/resin blend. Similar to what was observed for most of the other specified impurities, the ARB-B1 ring blanks appeared to contain 3 - 4 times more NU. Both ring blank sets also contained low enriched uranium, which was proposed to have come from uranium contamination in the graphite heat-treatment furnace. The LEU contamination was higher for the ARB-B1 ring blanks, presumably due to increasing levels of LEU contamination in the graphite furnace. 
Inspection Report Form IRF-20A: AGR-3/4 Matrix Ring Blanks

\begin{tabular}{|c|c|c|c|c|c|c|c|c|c|}
\hline \multicolumn{10}{|c|}{\begin{tabular}{l|l} 
Procedure: & AGR-CHAR-PIP-20 Rev. 1
\end{tabular}} \\
\hline \multirow{2}{*}{\multicolumn{10}{|c|}{\begin{tabular}{c|c|} 
Ring blank lot ID: & ARB-B1 \\
Ring blank lot description: Matrix Blend 1 with Hexion Durite SD-1708 resin
\end{tabular}}} \\
\hline & & & & & & & & & \\
\hline \multirow[b]{2}{*}{ Property } & \multicolumn{4}{|c|}{ Measured Data } & Specification & \multirow[b]{2}{*}{ Acceptance Criteria } & \multirow{2}{*}{$\begin{array}{l}\text { Acceptance } \\
\text { Test Value }\end{array}$} & \multirow{2}{*}{$\begin{array}{c}\text { Pass } \\
\text { or } \\
\text { fail } \\
\end{array}$} & \multirow{2}{*}{$\begin{array}{l}\text { Data } \\
\text { Records }\end{array}$} \\
\hline & $\begin{array}{c}\text { Mean } \\
(x)\end{array}$ & $\begin{array}{l}\text { Std. Dev. } \\
\text { (s) }\end{array}$ & \begin{tabular}{|c|} 
Measurements \\
$(n)$
\end{tabular} & \begin{tabular}{c|c|} 
Student's \\
t value
\end{tabular} & $\begin{array}{l}\text { INL SPC-1214 } \\
\text { Revision } 1 \\
\end{array}$ & & & & \\
\hline \multirow{2}{*}{$\begin{array}{l}\text { Ring blank diameter } \\
(\mathbf{m m})\end{array}$} & \multirow{2}{*}{25.64} & \multirow{2}{*}{0.08} & \multirow{2}{*}{50} & & $\begin{array}{c}\text { mean } \\
26.0 \pm 1.0 \\
\end{array}$ & \multicolumn{2}{|l|}{ see DRF-43 } & pass & \multirow{2}{*}{ DRF-43 } \\
\hline & & & & & $\begin{array}{l}\text { dispersion } \\
0 \%<24.5\end{array}$ & \multicolumn{2}{|l|}{ see DRF-43 } & pass & \\
\hline $\begin{array}{c}\text { Ring blank length } \\
(\mathbf{m m})\end{array}$ & 61.9 & 0.7 & 50 & & $\begin{array}{c}\text { mean } \\
63.0 \pm 2.0 \\
\end{array}$ & \multicolumn{2}{|l|}{ see DRF-43 } & pass & DRF-43 \\
\hline \multirow{2}{*}{$\begin{array}{l}\text { Ring blank matrix density } \\
\qquad(\mathrm{g} / \mathrm{cm} 3)\end{array}$} & \multirow{2}{*}{1.79} & \multirow{2}{*}{0.03} & \multirow{2}{*}{50} & & $\begin{array}{c}\text { mean } \\
1.65 \pm 0.15 \\
\end{array}$ & \multicolumn{2}{|l|}{ see DRF-43 } & fail & \multirow{2}{*}{ DRF-43 } \\
\hline & & & & & $\begin{array}{l}\text { dispersion } \\
0 \%<1.5\end{array}$ & \multicolumn{2}{|l|}{ see DRF-43 } & pass & \\
\hline $\begin{array}{c}\text { Iron content } \\
(\mathrm{ppmw})\end{array}$ & 2.90 & 0.17 & 4 & 2.353 & $\begin{array}{l}\text { mean } \\
\leq 20\end{array}$ & $B=x+t s / \sqrt{ } n \leq 20$ & 3.10 & pass & $\begin{array}{l}\text { IRF-20B } \\
\text { DRF-44 }\end{array}$ \\
\hline $\begin{array}{l}\text { Chromium content } \\
\text { (ppmw Fe) }\end{array}$ & 0.050 & 0.010 & 4 & 2.353 & $\begin{array}{l}\text { mean } \\
\leq 10\end{array}$ & $B=x+t s / \sqrt{ } n \leq 10$ & 0.06 & pass & $\begin{array}{l}\text { IRF-20B } \\
\text { DRF-44 }\end{array}$ \\
\hline $\begin{array}{l}\text { Manganese content } \\
(\text { ppmw Mn) }\end{array}$ & 0.0011 & 0.0001 & 4 & 2.353 & $\begin{array}{l}\text { mean } \\
\leq 10 \\
\end{array}$ & $B=x+t s / \sqrt{ } n \leq 10$ & 0.00 & pass & $\begin{array}{l}\text { IRF-20B } \\
\text { DRF-44 } \\
\end{array}$ \\
\hline $\begin{array}{l}\text { Cobalt content } \\
\text { (ppmw Co) }\end{array}$ & 0.0038 & 0.0003 & 4 & 2.353 & $\begin{array}{l}\text { mean } \\
\leq 10\end{array}$ & $B=x+t s / \sqrt{n} \leq 10$ & 0.00 & pass & $\begin{array}{l}\text { IRF-20B } \\
\text { DRF-44 }\end{array}$ \\
\hline $\begin{array}{c}\text { Nickel content } \\
\text { (ppmw Ni) }\end{array}$ & 0.0328 & 0.0016 & 4 & 2.353 & $\begin{array}{l}\text { mean } \\
\leq 10\end{array}$ & $\mathrm{~B}=\mathrm{x}+\mathrm{ts} / \sqrt{\mathrm{n}} \leq 10$ & 0.03 & pass & $\begin{array}{l}\text { IRF-20B } \\
\text { DRF-44 }\end{array}$ \\
\hline $\begin{array}{l}\text { Calcium content } \\
\text { (ppmw Ca) }\end{array}$ & 7.29 & 0.22 & 4 & 2.353 & $\begin{array}{l}\text { mean } \\
\leq 45\end{array}$ & $B=x+t s / \sqrt{ } n \leq 45$ & 7.55 & pass & $\begin{array}{l}\text { IRF-20B } \\
\text { DRF-44 }\end{array}$ \\
\hline $\begin{array}{c}\text { Aluminum content } \\
\text { (ppmw AI) }\end{array}$ & 24.6 & 0.4 & 4 & 2.353 & $\begin{array}{l}\text { mean } \\
\leq 20\end{array}$ & $B=x+t s / \sqrt{n} \leq 20$ & 25.07 & fail & $\begin{array}{l}\text { IRF-20B } \\
\text { DRF-44 }\end{array}$ \\
\hline $\begin{array}{l}\text { Titanium plus Vanadium content } \\
(\mathrm{ppmw} \text { total } \mathrm{T}+\mathrm{V})\end{array}$ & 3.98 & 0.08 & 4 & 2.353 & $\begin{array}{l}\text { mean } \\
\leq 85\end{array}$ & $B=x+t s / \sqrt{ } n \leq 85$ & 4.07 & pass & $\begin{array}{l}\text { IRF-20B } \\
\text { DRF-44 }\end{array}$ \\
\hline $\begin{array}{c}\text { Uranium contamination } \\
(\text { (ppmw U) }\end{array}$ & 0.6 & 0.90 & 4 & 2.353 & $\begin{array}{l}\text { mean } \\
\leq 0.5\end{array}$ & $B=x+t s / \sqrt{ } n \leq 0.5$ & 1.66 & fail & $\begin{array}{l}\text { IRF-20B } \\
\text { DRF-44 }\end{array}$ \\
\hline
\end{tabular}

\section{Comments}

Nineteen ring blanks were outside the specifled range for density, with measured average densities ranging from 1.80 to $1.83 \mathrm{~g} / \mathrm{cc}$. These ring blanks were used for destructive analysis or retained at ORNL. See NCR-X-AGR-11-01. The thirty ring blanks shipped to INL were within the specified range for density.

Average aluminum content was $~ 25 \%$ higher than the specifled limit. Disposition was to use as is. See NCR-X-AGR-11-02.

Average uranium content was $\sim 20 \%$ higher than the specified limit. Four groups of 3 ring blanks each were analyzed. One group showed an above average $U$ content ( 1.95 ppmw),

indicating abnormal contamination was introduced during fabrication of one or more ring blanks in the sample or during analysis. The mean uranium content based on the other 3

sample groups is $0.10 \mathrm{ppmw}$, with a standard deviation of $0.03 \mathrm{ppmw}$, which yields a passing acceptance test value of 0.15 . Disposition was to use as is. See NCR-X-AGR-11-03.

All impurity content results are from IRF-20B Supplemental, which includes analysis of residual ash left behind after nitric acid leaching.

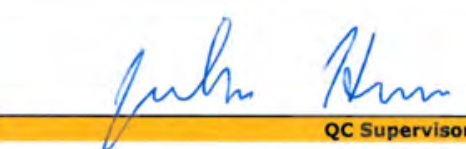

\section{Accept ring blank lot (Yes or No)?}

Yes

\section{$9-14-11$}

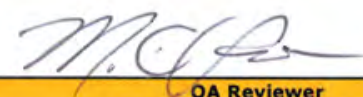

QA Reviewer

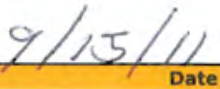


Inspection Report Form IRF-20B Supplemental: Summary of Impurities in Ring Blanks Including Analysis of Ash Residue

\begin{tabular}{|c|c|}
\hline Procedure: & AGR-CHAR-PIP-20 Rev. 1 \\
\hline Operator: & Fred Montgomery \\
\hline Ring blank lot ID: & ARB-B1 \\
\hline Ring blank lot description: & Matrix Blend I with Hexion Durite SD-1708 resin \\
\hline
\end{tabular}

\begin{tabular}{|c|c|c|c|c|c|c|}
\hline Ring blank ID numbers: & $\begin{array}{c}\text { Z026, Z015, } \\
\text { Z014 }\end{array}$ & $\begin{array}{c}\mathrm{z} 003, \mathrm{z041} \\
\mathrm{z} 025\end{array}$ & $\begin{array}{c}\text { z035, z027, } \\
\text { zo40 }\end{array}$ & $\begin{array}{c}\text { Z019, Z036, } \\
\text { Z044 }\end{array}$ & Mean & $\begin{array}{l}\text { Standard } \\
\text { Deviation }\end{array}$ \\
\hline \multicolumn{5}{|l|}{ Uranium } & \multicolumn{2}{|c|}{ Uranium } \\
\hline Impurity content detected by acid leach (ppmw) & 0.075 & 0.044 & 1.925 & 0.088 & 0.5 & 0.9 \\
\hline Impurity content detected in ash (ppmw) & 0.033 & 0.022 & 0.029 & 0.039 & 0.031 & 0.007 \\
\hline Total impurity content in ring blanks (ppmw) & 0.107 & 0.066 & 1.954 & 0.127 & 0.6 & 0.9 \\
\hline \multicolumn{5}{|l|}{ Iron } & \multicolumn{2}{|c|}{ Iron } \\
\hline Impurity content detected by acid leach (ppmw) & 2.434 & 2.429 & 2.424 & 2.138 & 2.36 & 0.15 \\
\hline Impurity content detected in ash (ppmw) & 0.536 & 0.610 & 0.509 & 0.518 & 0.54 & 0.05 \\
\hline Total impurity content in ring blanks (ppmw) & 2.969 & 3.040 & 2.932 & 2.656 & 2.90 & 0.17 \\
\hline \multicolumn{5}{|l|}{ Chromium } & \multicolumn{2}{|c|}{ Chromium } \\
\hline Impurity content detected by acid leach (ppmw) & 0.062 & 0.048 & 0.040 & 0.044 & 0.049 & 0.009 \\
\hline Impurity content detected in ash (ppmw) & 0.0013 & 0.0011 & 0.0008 & 0.0008 & 0.0010 & 0.0002 \\
\hline Total impurity content in ring blanks (ppmw) & 0.063 & 0.049 & 0.041 & 0.045 & 0.050 & 0.010 \\
\hline \multicolumn{5}{|l|}{ Manganese } & \multicolumn{2}{|c|}{ Manganese } \\
\hline Impurity content detected by acid leach (ppmw) & $<0.0008$ & $<0.0008$ & $<0.0007$ & $<0.0009$ & $<0.0008$ & 0.0001 \\
\hline Impurity content detected in ash (ppmw) & $<0.0003$ & $<0.0003$ & $<0.0003$ & $<0.0003$ & $<0.0003$ & 0.0000 \\
\hline Total impurity content in ring blanks (ppmw) & $<0.0010$ & $<0.0011$ & $<0.0010$ & $<0.0011$ & $<0.0011$ & 0.0001 \\
\hline \multicolumn{5}{|l|}{ Cobalt } & \multicolumn{2}{|c|}{ Cobalt } \\
\hline Impurity content detected by acid leach (ppmw) & $<0.0028$ & $<0.0026$ & $<0.0025$ & $<0.0023$ & $<0.0026$ & 0.0002 \\
\hline Impurity content detected in ash (ppmw) & 0.0013 & 0.0013 & 0.0012 & 0.0012 & 0.0013 & 0.0001 \\
\hline Total impurity content in ring blanks (ppmw) & $<0.0041$ & $<0.0040$ & $<0.0037$ & $<0.0036$ & $<0.0038$ & 0.0003 \\
\hline \multicolumn{5}{|l|}{ Nickel } & \multicolumn{2}{|c|}{ Nickel } \\
\hline Impurity content detected by acid leach (ppmw) & $<0.0277$ & 0.0284 & $<0.0258$ & $<0.0271$ & $<0.0272$ & 0.0011 \\
\hline Impurity content detected in ash (ppmw) & 0.0060 & 0.0053 & 0.0046 & 0.0062 & 0.0055 & 0.0007 \\
\hline Total impurity content in ring blanks (ppmw) & $<0.0337$ & 0.0337 & $<0.0304$ & $<0.0333$ & $<0.0328$ & 0.0016 \\
\hline \multicolumn{5}{|l|}{ Calcium } & \multicolumn{2}{|c|}{ Calcium } \\
\hline Impurity content detected by acid leach (ppmw) & 4.335 & 4.522 & 4.276 & 4.494 & 4.41 & 0.12 \\
\hline Impurity content detected in ash (ppmw) & 2.833 & 2.787 & 2.822 & 3.096 & 2.88 & 0.14 \\
\hline Total impurity content in ring blanks (ppmw) & 7.168 & 7.309 & 7.098 & 7.590 & 7.29 & 0.22 \\
\hline \multicolumn{5}{|l|}{ Aluminum } & \multicolumn{2}{|c|}{ Aluminum } \\
\hline Impurity content detected by acid leach (ppmw) & 13.002 & 13.797 & 13.119 & 12.870 & 13.2 & 0.4 \\
\hline Impurity content detected in ash (ppmw) & 11.773 & 10.870 & 10.935 & 12.088 & 11.4 & 0.6 \\
\hline Total impurity content in ring blanks (ppmw) & 24.774 & 24.667 & 24.055 & 24.958 & 24.6 & 0.4 \\
\hline \multicolumn{5}{|l|}{ Titanium } & \multicolumn{2}{|c|}{ Titanium } \\
\hline Impurity content detected by acid leach (ppmw) & 1.348 & 1.249 & 1.296 & 1.275 & 1.29 & 0.04 \\
\hline Impurity content detected in ash (ppmw) & 0.589 & 0.582 & 0.551 & 0.507 & 0.56 & 0.04 \\
\hline Total impurity content in ring blanks (ppmw) & 1.937 & 1.830 & 1.846 & 1.782 & 1.85 & 0.06 \\
\hline \multicolumn{5}{|l|}{ Vanadium } & \multicolumn{2}{|c|}{ Vanadium } \\
\hline Impurity content detected by acid leach (ppmw) & 2.124 & 2.125 & 2.080 & 2.076 & 2.10 & 0.03 \\
\hline Impurity content in residual ash (ppmw) & 0.028 & 0.032 & 0.031 & 0.027 & 0.030 & 0.002 \\
\hline Total impurity content in ring blanks (ppmw) & 2.152 & 2.157 & 2.111 & 2.103 & 2.13 & 0.03 \\
\hline \multicolumn{5}{|l|}{ Titanium plus Vanadium } & \multicolumn{2}{|c|}{ Titanium plus Vanadium } \\
\hline Impurity content detected by acid leach (ppmw) & 3.473 & 3.374 & 3.375 & 3.351 & 3.39 & 0.05 \\
\hline Impurity content detected in ash (ppmw) & 0.617 & 0.614 & 0.582 & 0.534 & 0.59 & 0.04 \\
\hline Total impurity content in ring blanks (ppmw) & 4.089 & 3.988 & 3.957 & 3.885 & 3.98 & 0.08 \\
\hline
\end{tabular}

Comments

Total impurity content in this table is the sum of the impurities detected by the standard burn-leach procedure plus the impurities detected by

microwave digestion of the ash residue remaining after the standard burn-leach in nitric acid. Approximately $75 \mathrm{wt} \%$ of the residual ash remained after microwave digestion. In addition to the impurities reported in the table, appreciable amounts of $\mathrm{Si}, \mathrm{Ba}, \mathrm{Mg}$, and $\mathrm{Zr}$ were also detected in the ash.
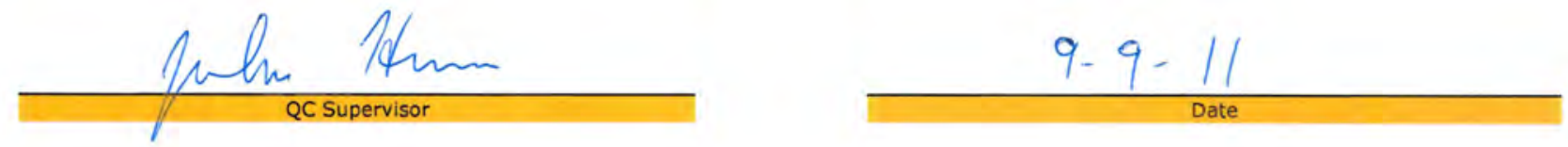
Inspection Report Form IRF-20C: Ring Blank Tracking

Procedure: AGR-CHAR-PIP-20 Rev. 1

Ring blank lot ID: ARB-B1

Ring blank lot description: Matrix Blend 1 with Hexion Durite SD-1708 resin

\begin{tabular}{|c|c|}
\hline $\begin{array}{c}\text { Ring Blank } \\
\text { Z Number }\end{array}$ & $\begin{array}{c}\text { Ring Blank } \\
\text { G Number }\end{array}$ \\
\hline Z001 & G023 \\
\hline Z002 & G003 \\
\hline Z003 & G012 \\
\hline Z004 & G006 \\
\hline Z005 & G025 \\
\hline Z006 & G041 \\
\hline Z007 & G037 \\
\hline Z008 & G029 \\
\hline Z009 & G014 \\
\hline Z010 & G031 \\
\hline Z011 & G001 \\
\hline Z012 & G046 \\
\hline Z013 & G036 \\
\hline Z014 & G038 \\
\hline Z015 & G013 \\
\hline
\end{tabular}

\begin{tabular}{|c|c|}
\hline $\begin{array}{c}\text { Ring Blank } \\
\text { Z Number }\end{array}$ & $\begin{array}{c}\text { Ring Blank } \\
\text { G Number }\end{array}$ \\
\hline Z016 & G051 \\
\hline Z017 & G017 \\
\hline Z018 & G032 \\
\hline Z019 & G016 \\
\hline Z020 & G028 \\
\hline Z021 & G002 \\
\hline Z022 & G027 \\
\hline Z023 & G026 \\
\hline Z024 & G008 \\
\hline Z025 & G052 \\
\hline Z026 & G042 \\
\hline Z027 & G018 \\
\hline Z028 & G020 \\
\hline Z029 & G019 \\
\hline Z030 & G049 \\
\hline
\end{tabular}

\begin{tabular}{|c|c|}
\hline $\begin{array}{c}\text { Ring Blank } \\
\text { Z Number }\end{array}$ & $\begin{array}{c}\text { Ring Blank } \\
\text { G Number }\end{array}$ \\
\hline Z031 & G024 \\
\hline Z032 & G015 \\
\hline Z033 & G039 \\
\hline Z034 & G044 \\
\hline Z035 & G047 \\
\hline Z036 & G040 \\
\hline Z037 & G050 \\
\hline Z038 & G021 \\
\hline Z039 & G034 \\
\hline Z040 & G010 \\
\hline Z041 & G043 \\
\hline Z042 & G007 \\
\hline Z043 & G009 \\
\hline Z044 & G045 \\
\hline Z045 & G005 \\
\hline
\end{tabular}

\begin{tabular}{|c|c|}
\hline $\begin{array}{c}\text { Ring Blank } \\
\text { Z Number }\end{array}$ & $\begin{array}{c}\text { Ring Blank } \\
\text { G Number }\end{array}$ \\
\hline Z046 & G030 \\
\hline Z047 & G022 \\
\hline Z048 & G033 \\
\hline Z049 & G011 \\
\hline Z050 & G035 \\
\hline Z051 & \\
\hline Z052 & \\
\hline Z053 & \\
\hline Z054 & \\
\hline Z055 & \\
\hline Z056 & \\
\hline Z057 & \\
\hline Z058 & \\
\hline Z059 & \\
\hline Z060 & \\
\hline
\end{tabular}

\section{Comments}

Nineteen (19) ring blanks had an average matrix density above $1.8 \mathrm{~g} / \mathrm{cc}$. These 19 blanks plus the longest blank (G021) were separated from the lot and randomly assigned the $20 \mathrm{Z}$-numbers specified by PIP-20 for archive or burn-leach analysis. The remaining $30 \mathrm{Z}$-numbers were randomly assigned to the other ring blanks.

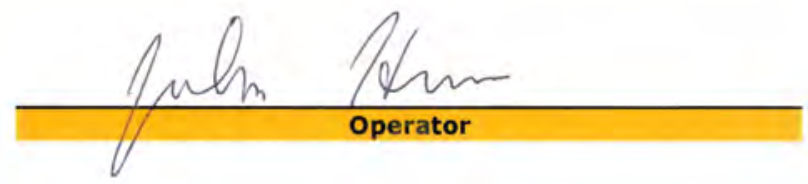

$8-9-11$ 
Data Report Form DRF-43: Matrix Ring Blank Diameter, Length, and Matrix Density

\begin{tabular}{|r|r|}
\hline Procedure: & AGR-CHAR-DAM-43 Rev. 0 \\
\hline Operator: & Dunbar \\
\hline Ring blank lot ID: & ARB-B1 \\
\hline Ring blank lot description: & Matrix Blend 1 with Hexion Durite SD-1708 resin \\
\hline Filename: & IImc-agr|AGRICompactDimensions (ringblanklotID_DRF43R0.xIS \\
\hline
\end{tabular}

\begin{tabular}{|c|l|}
\hline Vertical height gauge calibration due date: & $3 / 24 / 12$ \\
\hline Digital caliper calibration due date: & $5 / 5 / 12$ \\
\hline Gauge blocks calibration due date: & $2 / 27 / 13$ \\
\hline Analytical balance calibration due date: & $11 / 3 / 11$ \\
\hline
\end{tabular}

\begin{tabular}{|r|l|}
\hline Acceptance criteria for ring blank length: & $\geq 61.0$ and $\leq 65.0 \mathrm{~mm}$ \\
\hline Acceptance criteria for ring blank diameter: & $\geq 25.0$ and $\leq 27.0 \mathrm{~mm}$ \\
\hline Acceptance criteria for ring blank matrix density: & $\geq 1.50$ and $\leq 1.80 \mathrm{~g} / \mathrm{cm} 3$ \\
\hline
\end{tabular}
Acceptance criteria for ring blank matrix density: $\geq 1.50$ and $\leq 1.80 \mathrm{~g} / \mathrm{cm} 3$

\begin{tabular}{|c|c|c|c|c|c|c|c|c|}
\hline \multirow{2}{*}{$\begin{array}{l}\text { Ring Blank } \\
\text { Z Number }\end{array}$} & \multirow{2}{*}{$\begin{array}{l}\text { Weight } \\
\text { (g) }\end{array}$} & \multirow{2}{*}{$\begin{array}{l}\text { Length } \\
(\mathrm{mm})\end{array}$} & \multicolumn{3}{|c|}{ Diameter $(\mathrm{mm})$} & \multirow{2}{*}{$\begin{array}{l}\text { Volume } \\
(\mathrm{cm} 3)\end{array}$} & \multirow{2}{*}{$\begin{array}{c}\text { Matrix Density } \\
(\mathrm{g} / \mathrm{cm} 3)\end{array}$} & \multirow{2}{*}{$\begin{array}{c}\text { Accept? } \\
\text { (pass or fail) }\end{array}$} \\
\hline & & & Middle 1 & Middle 2 & Average & & & \\
\hline Z001 & 57.1101 & -6.302 & 25.76 & 25.75 & 25.76 & 33.020 & $-1.75^{2}$ & pass \\
\hline 2002 & 57.1694 & 62.994 & 25.79 & 25.78 & 25.79 & 32.895 & 1.74 & pass \\
\hline Z003 & 57.1528 & 60.986 & 25.58 & 25.56 & 25.57 & 31.317 & 1.82 & fail \\
\hline 2004 & 57.0601 & 62.424 & 25.72 & 25.71 & 25.72 & 32.420 & 1.76 & pass \\
\hline 2005 & 57.0568 & 62.708 & 25.73 & 25.71 & 25.72 & 32.580 & 1.75 & pass \\
\hline$Z 006$ & 56.9543 & 61.446 & 25.60 & 25.57 & 25.59 & 31.590 & 1.80 & fail \\
\hline $\mathrm{Z} 007$ & 57.0283 & 61.747 & 25.61 & 25.60 & 25.61 & 31.795 & 1.79 & pass \\
\hline$Z 008$ & 57.2630 & 61.295 & 25.57 & 25.57 & 25.57 & 31.476 & 1.82 & fail \\
\hline$Z 009$ & 57.2891 & 61.815 & 25.67 & 25.64 & 25.66 & 31.954 & 1.79 & pass \\
\hline $\mathrm{Z} 010$ & 56.9445 & 61.864 & 25.60 & 25.60 & 25.60 & 31.843 & 1.79 & pass \\
\hline 2011 & 57.1845 & 62.527 & 25.75 & 25.74 & 25.75 & 32.549 & 1.76 & pass \\
\hline $\mathrm{Z} 012$ & 56.9221 & 61.306 & 25.58 & 25.54 & 25.56 & 31.457 & 1.81 & fail \\
\hline 2013 & 56.9575 & 61.725 & 25.59 & 25.56 & 25.58 & 31.709 & 1.80 & pass \\
\hline 2014 & 57.0036 & 61.330 & 25.57 & 25.58 & 25.58 & 31.506 & 1.81 & fail \\
\hline 2015 & 57.0823 & 61.057 & 25.55 & 25.53 & 25.54 & 31.280 & 1.82 & fail \\
\hline Z017 & 57.3976 & 62.017 & 25.73 & 25.74 & 25.74 & 32.259 & 1.78 & pass \\
\hline Z018 & 57.0848 & 61.546 & 25.69 & 25.67 & 25.68 & 31.877 & 1.79 & pass \\
\hline Z019 & 57.2479 & 61.418 & 25.59 & 25.58 & 25.59 & 31.576 & 1.81 & fail \\
\hline$Z 020$ & 57.1220 & 62.510 & 25.69 & 25.68 & 25.69 & 32.389 & 1.76 & pass \\
\hline $\mathrm{Z} 021$ & 57.3822 & 63.172 & 25.82 & 25.82 & 25.82 & 33.077 & 1.73 & pass \\
\hline Z022 & 56.9280 & 62.302 & 25.74 & 25.68 & 25.71 & 32.344 & 1.76 & pass \\
\hline Z023 & 57.1619 & 62.189 & 25.67 & 25.67 & 25.67 & 32.185 & 1.78 & pass \\
\hline Z024 & 57.4121 & 62.901 & 25.76 & 25.77 & 25.77 & 32.795 & 1.75 & pass \\
\hline Z025 & 56.8281 & 61.015 & 25.53 & 25.54 & 25.54 & 31.246 & 1.82 & fail \\
\hline 2026 & 56.9123 & 61.217 & 25.52 & 25.53 & 25.53 & 31.325 & 1.82 & fail \\
\hline $\mathrm{Z027}$ & 57.2206 & 61.713 & 25.61 & 25.60 & 25.61 & 31.777 & 1.80 & fail \\
\hline Z028 & 57.3282 & 63.373 & 25.78 & 25.79 & 25.79 & 33.092 & 1.73 & pass \\
\hline 2029 & 57.4361 & 62.184 & 25.75 & 25.72 & 25.74 & 32.346 & 1.78 & pass \\
\hline 2030 & 56.9578 & 61.080 & 25.55 & 25.55 & 25.55 & 31.316 & 1.82 & fail \\
\hline
\end{tabular}

\section{Comments}

19 compacts had average matrix density above $1.8 \mathrm{~g} / \mathrm{cc}$. These compacts were used for impurity analysis or retained in ORNL archive.

30 compacts shipped to INL met all specified criteria for length, diameter, and matrix density.
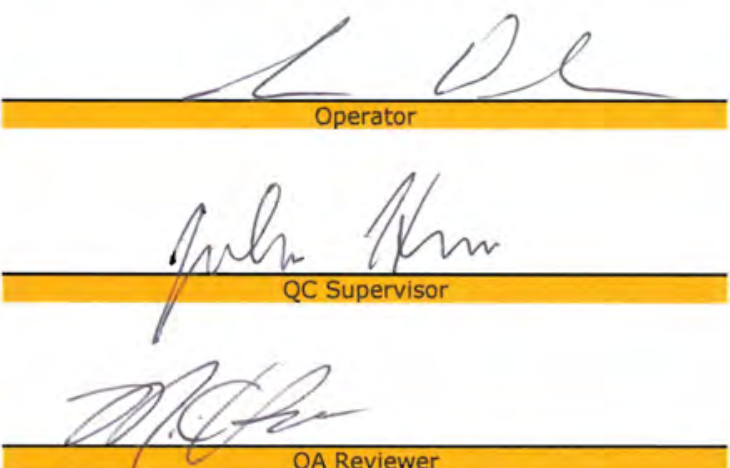

QA Reviewer

\section{$7-14-11$}

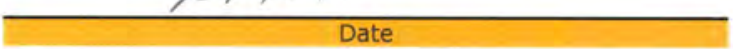

$8-9-11$

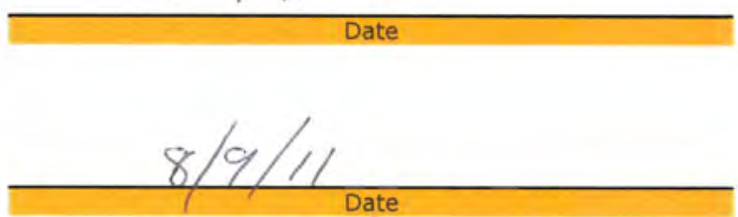




\section{Data Report Form DRF-43: Matrix Ring Blank Diameter, Length, and Matrix Density}

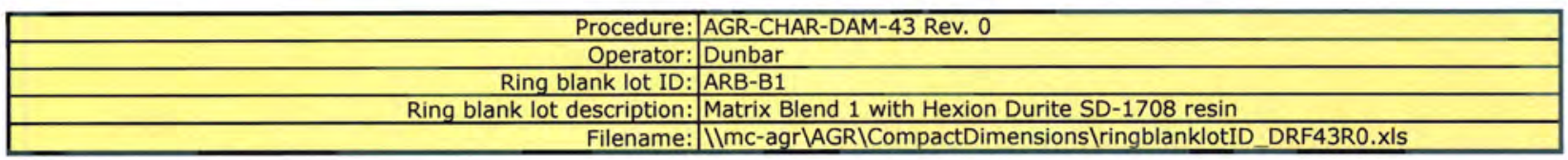

\begin{tabular}{|r|l|}
\hline Vertical height gauge calibration due date: & $3 / 24 / 12$ \\
\hline Digital caliper calibration due date: & $5 / 5 / 12$ \\
\hline Gauge blocks calibration due date: & $2 / 27 / 13$ \\
\hline Analytical balance calibration due date: & $11 / 3 / 11$ \\
\hline
\end{tabular}

Acceptance criteria for ring blank length: $\geq 61.0$ and $\leq 65.0 \mathrm{~mm}$ Acceptance criteria for ring blank diameter: $\geq 25.0$ and $\leq 27.0 \mathrm{~mm}$ Acceptance criteria for ring blank matrix density: $\geq 1.50$ and $\leq 1.80 \mathrm{~g} / \mathrm{cm} 3$

\begin{tabular}{|c|c|c|c|c|c|c|c|c|}
\hline \multirow{2}{*}{$\begin{array}{l}\text { Ring Blank } \\
\text { Z Number }\end{array}$} & \multirow{2}{*}{$\begin{array}{l}\text { Weight } \\
\text { (g) }\end{array}$} & \multirow{2}{*}{$\begin{array}{l}\text { Length } \\
(\mathrm{mm})\end{array}$} & \multicolumn{3}{|c|}{$\overline{\text { Diameter }(\mathrm{mm})}$} & \multirow{2}{*}{$\begin{array}{l}\text { Volume } \\
(\mathrm{cm} 3)\end{array}$} & \multirow{2}{*}{$\begin{array}{c}\text { Matrix Density } \\
(9 / \mathrm{cm} 3)\end{array}$} & \multirow{2}{*}{$\begin{array}{c}\text { Accept? } \\
\text { (pass or fail) }\end{array}$} \\
\hline & & & Middle 1 & Middle 2 & Average & & & \\
\hline Z031 & 57.0122 & 62.223 & 25.72 & 25.70 & 25.71 & 32.303 & 1.76 & pass \\
\hline Z032 & 57.1110 & 61.687 & 25.66 & 25.65 & 25.66 & 31.888 & 1.79 & pass \\
\hline 2033 & 57.0370 & 61.901 & 25.61 & 25.61 & 25.61 & 31.886 & 1.79 & pass \\
\hline 2034 & 56.9333 & 61.400 & 25.69 & 25.54 & 25.62 & 31.641 & 1.80 & pass \\
\hline 2035 & 57.0864 & 61.001 & 25.53 & 25.53 & 25.53 & 31.227 & 1.83 & fail \\
\hline 2036 & 57.0397 & 61.625 & 25.57 & 25.57 & 25.57 & 31.645 & 1.80 & fail \\
\hline 2037 & 56.8938 & 62.411 & 25.61 & 25.61 & 25.61 & 32.149 & 1.77 & pass \\
\hline Z038 & 57.2621 & 63.587 & 25.73 & 25.75 & 25.74 & 33.088 & 1.73 & pass \\
\hline 2039 & 57.0215 & 62.057 & 25.68 & 25.67 & 25.68 & 32.129 & 1.77 & pass \\
\hline $\mathrm{ZO40}$ & 57.1444 & 61.413 & 25.58 & 25.58 & 25.58 & 31.561 & 1.81 & fail \\
\hline Z041 & 56.9390 & 61.102 & 25.53 & 25.52 & 25.53 & 31.266 & 1.82 & fail \\
\hline Z042 & 57.4184 & 62.256 & 25.71 & 25.71 & 25.71 & 32.320 & 1.78 & pass \\
\hline Z043 & 57.2767 & 62.104 & 25.70 & 25.71 & 25.71 & 32.229 & 1.78 & pass \\
\hline Z044 & 56.9975 & 61.379 & 25.59 & 25.55 & 25.57 & 31.519 & 1.81 & fail \\
\hline 2045 & 57.1164 & 62.475 & 25.77 & 25.74 & 25.76 & 32.548 & 1.75 & pass \\
\hline$Z 046$ & 57.0645 & 62.170 & 25.82 & 25.61 & 25.72 & 32.288 & 1.77 & pass \\
\hline Z047 & 57.2916 & 62.763 & 25.74 & 25.74 & 25.74 & 32.660 & 1.75 & pass \\
\hline Z048 & 57.0247 & 61.954 & 25.63 & 25.63 & 25.63 & 31.964 & 1.78 & pass \\
\hline Z049 & 56.9952 & 60.829 & 25.56 & 25.53 & 25.55 & 31.175 & 1.83 & fail \\
\hline 2050 & 57.0537 & 61.316 & 25.58 & 25.56 & 25.57 & 31.487 & 1.81 & fail \\
\hline \multicolumn{9}{|l|}{2051} \\
\hline \multicolumn{9}{|l|}{ Z052 } \\
\hline \multicolumn{9}{|l|}{ Z053 } \\
\hline \multicolumn{9}{|l|}{ Z054 } \\
\hline \multicolumn{9}{|l|}{ Z055 } \\
\hline \multicolumn{9}{|l|}{2056} \\
\hline \multicolumn{9}{|l|}{2057} \\
\hline \multicolumn{9}{|l|}{ Z058 } \\
\hline \multicolumn{9}{|l|}{2059} \\
\hline$Z 060$ & & & & & & & & \\
\hline
\end{tabular}

Comments

19 compacts had average matrix density above $1.8 \mathrm{~g} / \mathrm{cc}$. These compacts were used for impurity analysis or retained in ORNL archive. 30 compacts shipped to INL met all specified criteria for length, diameter, and matrix density.
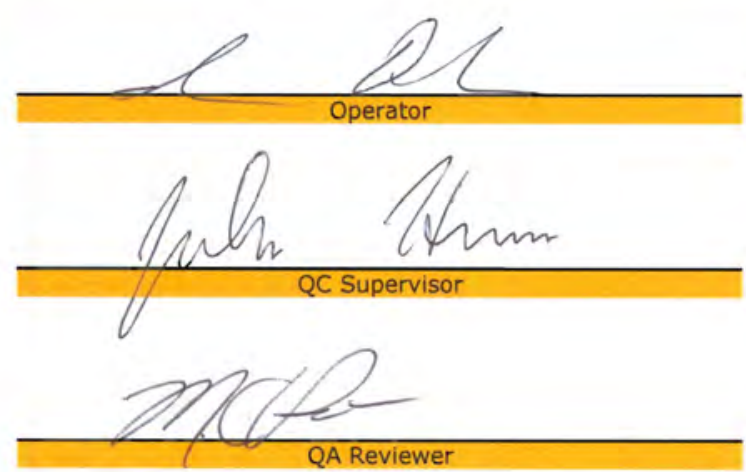

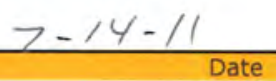

$8-9-11$

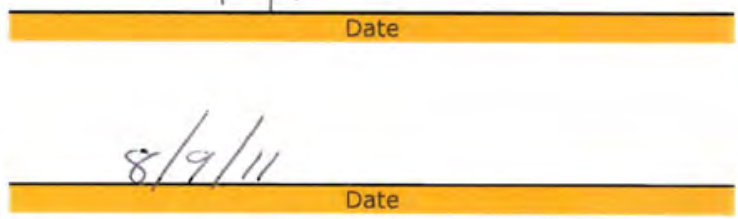


Data Report Form DRF-44: Measurement of Impurities in Matrix Ring Blanks by the Burn-Leach Method

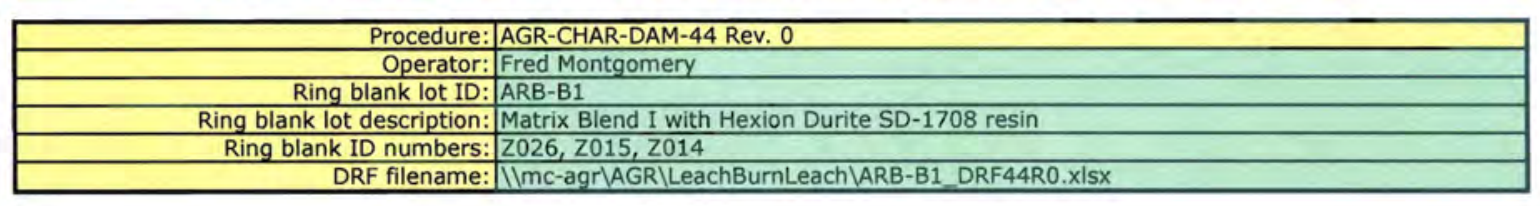

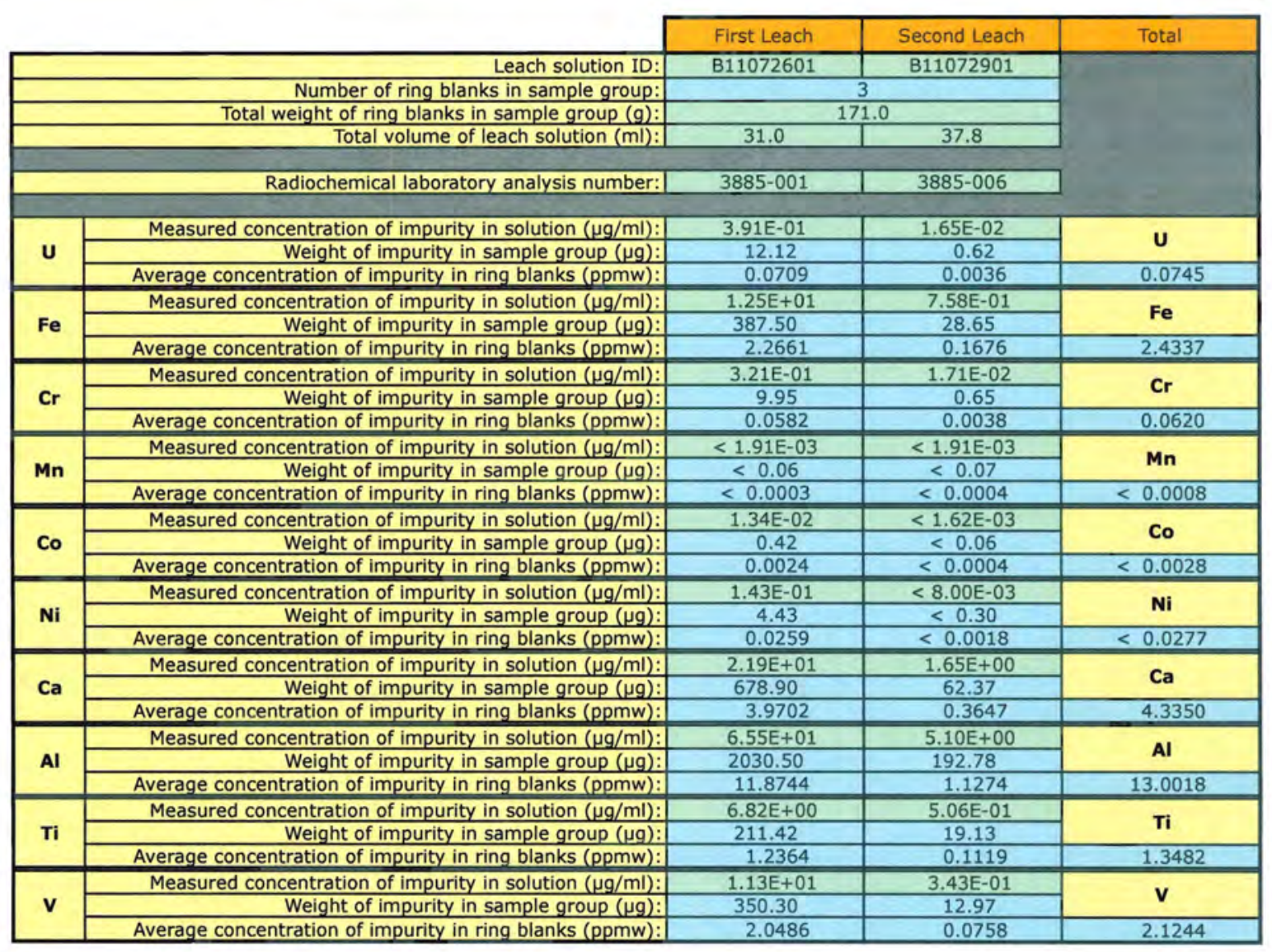

Weight of ash after nitric acid leaching was $0.171 \mathrm{~g}$.

Comments

Data checked by FCM against the official results of analyses for RMAL3885 on 8/16/2011.

Frederick C. Montyermey $q-1-2011$

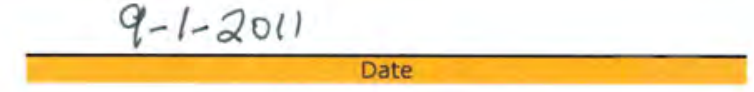




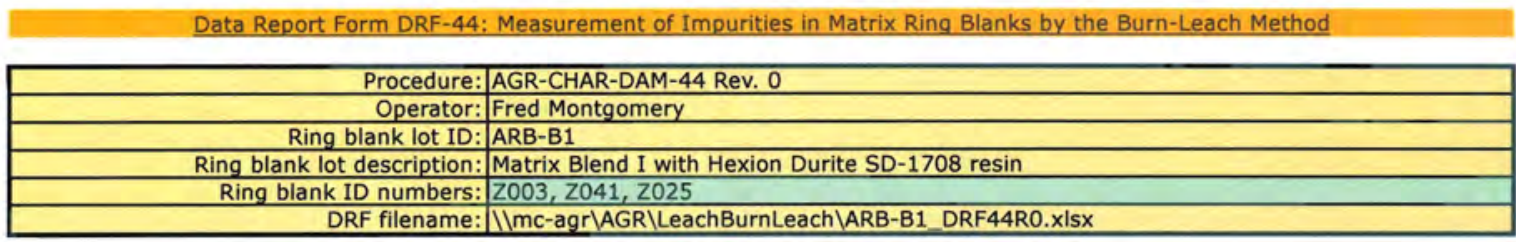

\begin{tabular}{|c|c|c|c|c|}
\hline & & First Leach & Second Leach & Total \\
\hline & Leach solution ID: & B11072602 & B11072902 & \\
\hline & Number of ring blanks in sample group: & \multicolumn{2}{|c|}{3} & \\
\hline & Total weight of ring blanks in sample group $(\mathrm{g})$ : & \multicolumn{2}{|c|}{170.9} & \\
\hline & Total volume of leach solution $(\mathrm{ml}):$ & 35.6 & 40.0 & \\
\hline & Radiochemical laboratory analysis number: & $3885-002$ & $3885-007$ & \\
\hline \multirow{3}{*}{$\mathbf{u}$} & Measured concentration of impurity in solution $(\mu \mathrm{g} / \mathrm{ml})$ : & $1.99 \mathrm{E}-01$ & $1.00 \mathrm{E}-02$ & \multirow{3}{*}{$\frac{\mathbf{U}}{0.0438}$} \\
\hline & Weight of impurity in sample group $(\mu \mathrm{g})$ : & 7.08 & 0.40 & \\
\hline & Average concentration of impurity in ring blanks (ppmw): & 0.0414 & 0.0023 & \\
\hline \multirow{3}{*}{$\mathbf{F e}$} & Measured concentration of impurity in solution $(\mu \mathrm{g} / \mathrm{ml})$ : & $1.08 \mathrm{E}+01$ & $7.69 \mathrm{E}-01$ & \multirow[b]{2}{*}{$\mathbf{F e}$} \\
\hline & Weight of impurity in sample group $(\mu g)$ : & 384.48 & 30.76 & \\
\hline & Average concentration of impurity in ring blanks (ppmw): & 2.2495 & 0.1800 & 2.4295 \\
\hline \multirow{3}{*}{ Cr } & Measured concentration of impurity in solution $(\mu \mathrm{g} / \mathrm{ml})$ : & $2.14 \mathrm{E}-01$ & $1.35 \mathrm{E}-02$ & \multirow[b]{2}{*}{$\mathbf{C r}$} \\
\hline & Weight of impurity in sample group $(\mu \mathrm{g})$ : & 7.62 & 0.54 & \\
\hline & Average concentration of impurity in ring blanks (ppmw): & 0.0446 & 0.0032 & 0.0477 \\
\hline \multirow{3}{*}{ Mn } & Measured concentration of impurity in solution $(\mu \mathrm{g} / \mathrm{ml})$ : & $<1.91 \mathrm{E}-03$ & $<1.91 \mathrm{E}-03$ & \multirow{2}{*}{ Mn } \\
\hline & Weight of impurity in sample group $(\mu g)$ : & $<0.07$ & $<0.08$ & \\
\hline & Average concentration of impurity in ring blanks (ppmw): & $<0.0004$ & $<0.0004$ & $<0.0008$ \\
\hline \multirow{3}{*}{ Co } & Measured concentration of impurity in solution $(\mu \mathrm{g} / \mathrm{ml})$ : & $1.09 \mathrm{E}-02$ & $<1.62 \mathrm{E}-03$ & \multirow{2}{*}{ Co } \\
\hline & Weight of impurity in sample group $(\mu \mathrm{g})$ : & 0.39 & $<0.06$ & \\
\hline & Average concentration of impurity in ring blanks (ppmw): & 0.0023 & $<0.0004$ & $<0.0026$ \\
\hline \multirow{3}{*}{$\mathbf{N i}$} & Measured concentration of impurity in solution $(\mu \mathrm{g} / \mathrm{ml})$ : & $1.27 \mathrm{E}-01$ & $8.28 \mathrm{E}-03$ & \multirow[b]{2}{*}{$\mathbf{N i}$} \\
\hline & $\begin{array}{l}\text { Weight of impurity in sample group }(\mu g) \text { : } \\
\text {. }\end{array}$ & 4.52 & 0.33 & \\
\hline & Average concentration of impurity in ring blanks (ppmw): & 0.0265 & 0.0019 & 0.0284 \\
\hline \multirow{3}{*}{ Ca } & Measured concentration of impurity in solution $(\mu \mathrm{g} / \mathrm{ml})$ : & $1.99 \mathrm{E}+01$ & $1.61 \mathrm{E}+00$ & \multirow[b]{2}{*}{$\mathbf{C a}$} \\
\hline & Weight of impurity in sample group $(\mu \mathrm{g})$ : & 708.44 & 64.40 & \\
\hline & Average concentration of impurity in ring blanks (ppmw): & 4.1449 & 0.3768 & 4.5217 \\
\hline \multirow{3}{*}{ Al } & Measured concentration of impurity in solution $(\mu \mathrm{g} / \mathrm{ml})$ : & $6.06 \mathrm{E}+01$ & $5.02 \mathrm{E}+00$ & \multirow{3}{*}{$\frac{\text { Al }}{13.7969}$} \\
\hline & Weight of impurity in sample group $(\mu \mathrm{g})$ : & 2157.36 & 200.80 & \\
\hline & Average concentration of impurity in ring blanks (ppmw): & 12.6221 & 1.1748 & \\
\hline \multirow{3}{*}{$\mathbf{T i}$} & Measured concentration of impurity in solution $(\mu \mathrm{g} / \mathrm{ml})$ : & $5.39 E+00$ & $5.38 \mathrm{E}-01$ & \multirow{2}{*}{$\mathbf{T i}$} \\
\hline & Weight of impurity in sample group $(\mu \mathrm{g})$ : & 191.88 & 21.52 & \\
\hline & Average concentration of impurity in ring blanks (ppmw): & 1.1227 & 0.1259 & 1.2486 \\
\hline \multirow{3}{*}{$\mathbf{v}$} & Measured concentration of impurity in solution $(\mu \mathrm{g} / \mathrm{ml})$ : & $9.96 \mathrm{E}+00$ & $2.17 E-01$ & \multirow{2}{*}{ v } \\
\hline & Weight of impurity in sample group $(\mu g)$ : & 354.58 & 8.68 & \\
\hline & Average concentration of impurity in ring blanks (ppmw): & 2.0745 & 0.0508 & 2.1253 \\
\hline
\end{tabular}

Weight of ash after nitric acid leaching was $0.159 \mathrm{~g}$.

Comments

Data checked by FCM against the official results of analyses for RMAL3885 on 8/16/2011.

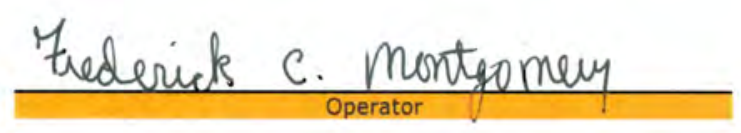

$$
9-1-2011
$$


Data Report Form DRF-44: Measurement of Impurities in Matrix Ring Blanks by the Burn-Leach Method

\begin{tabular}{|c|c|}
\hline Procedure: & AGR-CHAR-DAM-44 Rev. 0 \\
\hline Operator: & Fred Montgomery \\
\hline Ring blank lot ID: & ARB-B1 \\
\hline Ring blank lot description: & Matrix Blend I with Hexion Durite SD-1708 resin \\
\hline Ring blank ID numbers: & $\mathrm{ZO} 035, \mathrm{Z027}, \mathrm{Z040}$ \\
\hline DRF filename: & each \ARB-B1_DRF44R0.xisx \\
\hline
\end{tabular}

\begin{tabular}{|c|c|c|c|c|}
\hline & First Leach & Second Leach & Total \\
\hline & Leach solution ID: & B11072603 & B11072903 & \\
\hline & Number of ring blanks in sample group: & \multicolumn{2}{|l|}{ thes } & \\
\hline & Total weight of ring blanks in sample group (g): & \multicolumn{2}{|c|}{171.5} & \\
\hline & Total volume of leach solution $(\mathrm{ml})$ : & 32.8 & 32.5 & \\
\hline & Radiochemical laboratory analysis number: & $3885-003$ & $3885-008$ & \\
\hline \multirow{4}{*}{ u } & & & & \multirow{4}{*}{$\frac{\mathbf{U}}{1.9252}$} \\
\hline & Measured concentration of impurity in solution $(\mu \mathrm{g} / \mathrm{ml})$ : & $9.75 E+00$ & $3.16 \mathrm{E}-01$ & \\
\hline & Weight of impurity in sample group $(\mu \mathrm{g})$ : & 319.80 & 10.27 & \\
\hline & Average concentration of impurity in ring blanks (ppmw): & 1.8653 & 0.0599 & \\
\hline \multirow{3}{*}{$\mathrm{Fe}$} & Measured concentration of impurity in solution $(\mu \mathrm{g} / \mathrm{ml})$ : & 1.17E+01 & $9.77 \mathrm{E}-01$ & \multirow{2}{*}{$\mathrm{Fe}$} \\
\hline & Weight of impurity in sample group $(\mu \mathrm{g})$ : & 383.76 & 31.75 & \\
\hline & Average concentration of impurity in ring blanks (ppmw): & 2.2383 & 0.1852 & 2.4235 \\
\hline \multirow{3}{*}{ Cr } & Measured concentration of impurity in solution $(\mu \mathrm{g} / \mathrm{ml})$ : & $2.00 \mathrm{E}-01$ & $1.12 \mathrm{E}-02$ & \multirow[b]{2}{*}{$\mathrm{Cr}$} \\
\hline & Weight of impurity in sample group $(\mu g)$ : & 6.56 & 0.36 & \\
\hline & Average concentration of impurity in ring blanks (ppmw): & 0.0383 & 0.0021 & 0.0404 \\
\hline \multirow{3}{*}{ Mn } & Measured concentration of impurity in solution $(\mu \mathrm{g} / \mathrm{ml})$ : & $<1.91 \mathrm{E}-03$ & $<1.91 \mathrm{E}-03$ & \multirow{2}{*}{ Mn } \\
\hline & Weight of impurity in sample group $(\mu \mathrm{g})$ : & $<0.06$ & $<0.06$ & \\
\hline & Average concentration of impurity in ring blanks (ppmw): & $<0.0004$ & $<0.0004$ & $<0.0007$ \\
\hline \multirow{3}{*}{ Co } & Measured concentration of impurity in solution $(\mu \mathrm{g} / \mathrm{ml})$ : & $1.16 \mathrm{E}-02$ & $<1.62 \mathrm{E}-03$ & \multirow[b]{2}{*}{ Co } \\
\hline & $\begin{array}{l}\text { Weight of impurity in sample group }(\mu \mathrm{g}) \text { : } \\
\text { : }\end{array}$ & 0.38 & $<0.05$ & \\
\hline & Average concentration of impurity in ring blanks (ppmw): & 0.0022 & $<0.0003$ & $<0.0025$ \\
\hline \multirow{3}{*}{$\mathbf{N i}$} & Measured concentration of impurity in solution $(\mu \mathrm{g} / \mathrm{ml})$ : & $1.27 \mathrm{E}-01$ & $<8.00 \mathrm{E}-03$ & \multirow{2}{*}{$\mathrm{Ni}$} \\
\hline & Weight of impurity in sample group $(\mu \mathrm{g})$ : & 4.17 & $<0.26$ & \\
\hline & Average concentration of impurity in ring blanks (ppmw): & 0.0243 & $<0.0015$ & $<0.0258$ \\
\hline \multirow{3}{*}{$\mathbf{C a}$} & Measured concentration of impurity in solution $(\mu \mathrm{g} / \mathrm{ml})$ : & $2.05 E+01$ & $1.87 E+00$ & \multirow{2}{*}{$\mathrm{Ca}$} \\
\hline & Weight of impurity in sample group $(\mu \mathrm{g})$ : & 672.40 & 60.78 & \\
\hline & Average concentration of impurity in ring blanks (ppmw): & 3.9218 & 0.3545 & 4.2763 \\
\hline \multirow{3}{*}{ Al } & Measured concentration of impurity in solution $(\mu \mathrm{g} / \mathrm{ml})$ : & $6.28 \mathrm{E}+01$ & $5.83 E+00$ & \multirow[b]{2}{*}{ Al } \\
\hline & Weight of impurity in sample group $(\mu \mathrm{g})$ : & 2059.84 & 189.48 & \\
\hline & Average concentration of impurity in ring blanks (ppmw): & 12.0141 & 1.1051 & 13.1193 \\
\hline \multirow{3}{*}{$\mathbf{T i}$} & Measured concentration of impurity in solution $(\mu \mathrm{g} / \mathrm{ml})$ : & $6.15 E+00$ & $6.28 \mathrm{E}-01$ & \multirow{2}{*}{$\mathbf{T i}$} \\
\hline & Weight of impurity in sample group $(\mu \mathrm{g})$ : & 201.72 & 20.41 & \\
\hline & Average concentration of impurity in ring blanks (ppmw): & 1.1765 & 0.1190 & 1.2956 \\
\hline \multirow{3}{*}{$\mathbf{v}$} & Measured concentration of impurity in solution $(\mu \mathrm{g} / \mathrm{ml})$ : & $1.05 E+01$ & $3.74 \mathrm{E}-01$ & \multirow[b]{2}{*}{$\mathbf{v}$} \\
\hline & Weight of impurity in sample group $(\mu \mathrm{g})$ : & 344.40 & 12.16 & \\
\hline & Average concentration of impurity in ring blanks (ppmw): & 2.0087 & 0.0709 & 2.0796 \\
\hline \\
\hline \multicolumn{5}{|c|}{$\begin{array}{l}\text { Weight of ash after nitric acid leaching was } 0.167 \mathrm{~g} \text {. } \\
\text { Data checked by FCM against the official results of analyses for RMAL3885 on 8/16/2011. }\end{array}$} \\
\hline
\end{tabular}

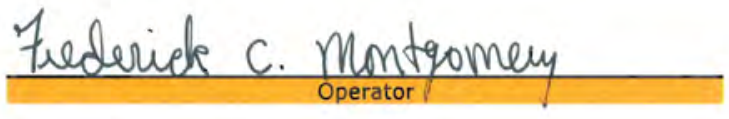

$9-1-2011$

Date 
Data Report Form DRF-44: Measurement of Impurities in Matrix Rinq Blanks by the Burn-Leach Method

\begin{tabular}{|c|c|}
\hline Procedure: & AGR-CHAR-DAM-44 Rev. 0 \\
\hline Operator: & Fred Montgomery \\
\hline Ring blank lot ID: & ARB-B1 \\
\hline Ring blank lot description: & Matrix Blend I with Hexion Durite SD-1708 resin \\
\hline Ring blank ID numbers: & $\mathrm{Z019}, \mathrm{Z036}, \mathrm{Z044}$ \\
\hline DRF filename: & IImc-agr\AGR\Leac \\
\hline
\end{tabular}

\begin{tabular}{|c|c|c|c|c|}
\hline & & First Leach & Second Leach & Total \\
\hline & Leach solution ID: & B11072604 & B11072904 & \\
\hline & Number of ring blanks in sample group: & \multicolumn{2}{|c|}{3} & \\
\hline & Total weight of ring blanks in sample group $(g)$ : & \multicolumn{2}{|c|}{171.5} & \\
\hline & Total volume of leach solution $(\mathrm{ml})$ : & 36.3 & 41.0 & \\
\hline & Radiochemical laboratory analysis number: & $3885-004$ & $3885-009$ & \\
\hline \multirow{3}{*}{$\mathbf{u}$} & Measured concentration of impurity in solution $(\mu \mathrm{g} / \mathrm{ml})$ : & $3.93 \mathrm{E}-01$ & $2.07 E-02$ & \multirow{2}{*}{ u } \\
\hline & Weight of impurity in sample group $(\mu g)$ : & 14.27 & 0.85 & \\
\hline & Average concentration of impurity in ring blanks (ppmw): & 0.0832 & 0.0049 & 0.0881 \\
\hline \multirow{3}{*}{$\mathbf{F e}$} & Measured concentration of impurity in solution $(\mu \mathrm{g} / \mathrm{ml})$ : & $9.33 \mathrm{E}+00$ & $6.84 \mathrm{E}-01$ & \multirow{2}{*}{$\mathrm{Fe}$} \\
\hline & Weight of impurity in sample group $(\mu \mathrm{g})$ : & 338.68 & 28.04 & \\
\hline & Average concentration of impurity in ring blanks (ppmw): & 1.9744 & 0.1635 & 2.1379 \\
\hline \multirow{3}{*}{$\mathbf{C r}$} & Measured concentration of impurity in solution $(\mu \mathrm{g} / \mathrm{ml})$ : & $1.96 \mathrm{E}-01$ & $1.25 \mathrm{E}-02$ & \multirow{2}{*}{$\mathrm{Cr}$} \\
\hline & $\begin{array}{l}\text { Weight of impurity in sample group }(\mu g) \text { : } \\
\text {. }\end{array}$ & 7.11 & 0.51 & \\
\hline & Average concentration of impurity in ring blanks (ppmw): & 0.0415 & 0.0030 & 0.0445 \\
\hline \multirow{3}{*}{ Mn } & Measured concentration of impurity in solution $(\mu \mathrm{g} / \mathrm{ml})$ : & $<1.91 \mathrm{E}-03$ & $<1.91 \mathrm{E}-03$ & \multirow{2}{*}{ Mn } \\
\hline & Weight of impurity in sample group $(\mu \mathrm{g})$ : & $<0.07$ & $<0.08$ & \\
\hline & Average concentration of impurity in ring blanks (ppmw): & $<0.0004$ & $<0.0005$ & $<0.0009$ \\
\hline \multirow{3}{*}{ Co } & Measured concentration of impurity in solution $(\mu \mathrm{g} / \mathrm{ml})$ : & $9.24 \mathrm{E}-03$ & $<1.62 \mathrm{E}-03$ & \multirow{2}{*}{ Co } \\
\hline & Weight of impurity in sample group $(\mu g)$ : & 0.34 & $<0.07$ & \\
\hline & Average concentration of impurity in ring blanks (ppmw): & 0.0020 & $<0.0004$ & $<0.0023$ \\
\hline \multirow{3}{*}{$\mathbf{N i}$} & Measured concentration of impurity in solution $(\mu \mathrm{g} / \mathrm{ml})$ : & $1.19 \mathrm{E}-01$ & $<8.00 \mathrm{E}-03$ & \multirow{2}{*}{ Ni } \\
\hline & Weight of impurity in sample group $(\mu \mathrm{g})$ : & 4.32 & $<0.33$ & \\
\hline & Average concentration of impurity in ring blanks (ppmw): & 0.0252 & $<0.0019$ & $<0.0271$ \\
\hline \multirow{3}{*}{$\mathbf{C a}$} & Measured concentration of impurity in solution $(\mu \mathrm{g} / \mathrm{ml})$ : & $1.91 \mathrm{E}+01$ & $1.89 E+00$ & \multirow{2}{*}{$\mathrm{Ca}$} \\
\hline & Weight of impurity in sample group $(\mu \mathrm{g})$ : & 693.33 & 77.49 & \\
\hline & Average concentration of impurity in ring blanks (ppmw): & 4.0419 & 0.4517 & 4.4936 \\
\hline \multirow{3}{*}{ Al } & Measured concentration of impurity in solution $(\mu \mathrm{g} / \mathrm{ml})$ : & $5.42 \mathrm{E}+01$ & $5.86 \mathrm{E}+00$ & \multirow{2}{*}{ Al } \\
\hline & Weight of impurity in sample group $(\mu g)$ : & 1967.46 & 240.26 & \\
\hline & Average concentration of impurity in ring blanks (ppmw): & 11.4697 & 1.4006 & 12.8703 \\
\hline \multirow{3}{*}{$\mathbf{T i}$} & Measured concentration of impurity in solution $(\mu \mathrm{g} / \mathrm{ml})$ : & $5.40 \mathrm{E}+00$ & $5.54 \mathrm{E}-01$ & \multirow[b]{2}{*}{$\mathbf{T i}$} \\
\hline & Weight of impurity in sample group $(\mu \mathrm{g})$ : & 196.02 & 22.71 & \\
\hline & Average concentration of impurity in ring blanks (ppmw): & 1.1427 & 0.1324 & 1.2752 \\
\hline \multirow{3}{*}{$\mathbf{v}$} & Measured concentration of impurity in solution $(\mu \mathrm{g} / \mathrm{ml})$ : & $9.39 \mathrm{E}+00$ & $3.72 \mathrm{E}-01$ & \multirow[b]{2}{*}{$\mathbf{v}$} \\
\hline & Weight of impurity in sample group $(\mu \mathrm{g})$ : & 340.86 & 15.25 & \\
\hline & Average concentration of impurity in ring blanks (ppmw): & 1.9871 & 0.0889 & 2.0760 \\
\hline
\end{tabular}

Weight of ash after nitric acid leaching was $0.160 \mathrm{~g}$.

\section{Comments}

Data checked by FCM against the official results of analyses for RMAL3885 on 8/16/2011.

\section{Trederisk c. Montgomeey}

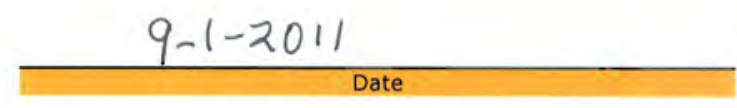


Data Report Form DRF-44: Measurement of Impurities in Matrix Ring Blanks by the Burn-Leach Method

\begin{tabular}{|c|c|}
\hline Procedure: & AGR-CHAR-DAM-44 Rev. 0 \\
\hline Operator: & Fred Montgomery \\
\hline Ring blank lot ID: & ARB-B1 \\
\hline Ring blank lot description: & Matrix Blend I with Hexion Durite SD-1708 resin \\
\hline Ring blank ID numbers: & Blank \\
\hline DRF filename: & \Imc-agr\AGR\LeachBurnLeach\ARB-B1_DRF44R0.xIsx \\
\hline
\end{tabular}

\begin{tabular}{|c|c|c|c|c|}
\hline & & First Leach & Second Leach & Total \\
\hline & Leach solution ID: & B11072605 & B11072905 & \\
\hline \multirow{2}{*}{\multicolumn{2}{|c|}{$\begin{array}{l}\text { Number of ring blanks in sample group: } \\
\text { Total weight of ring blanks in sample group }(\mathrm{g}) \text { : }\end{array}$}} & \multicolumn{2}{|c|}{1} & \\
\hline & & & & \\
\hline \multicolumn{2}{|r|}{ Total volume of leach solution $(\mathrm{ml})$ : } & 41.5 & 39.0 & \\
\hline \multicolumn{2}{|r|}{ Radiochemical laboratory analysis number: } & $3885-005$ & $3885-010$ & \\
\hline \multirow{3}{*}{$\mathbf{u}$} & Measured concentration of impurity in solution $(\mu \mathrm{g} / \mathrm{ml})$ : & $2.33 E-03$ & $3.23 E-03$ & \multirow[b]{2}{*}{$\mathbf{U}$} \\
\hline & Weight of impurity in sample group $(\mu \mathrm{g})$ : & 0.10 & 0.13 & \\
\hline & Total Weight of impurity detected (ug): & & & \multirow{3}{*}{$\mathrm{Fe}$} \\
\hline \multirow{3}{*}{$\mathbf{F e}$} & Measured concentration of impurity in solution $(\mu \mathrm{g} / \mathrm{ml})$ : & $9.14 \mathrm{E}-02$ & $<4.12 \mathrm{E}-02$ & \\
\hline & Weight of impurity in sample group $(\mu g)$ : & 3.79 & $<1.61$ & \\
\hline & Total Weight of impurity detected $(\mu \mathrm{g})$ : & & & \multirow[b]{3}{*}{$\mathrm{Cr}$} \\
\hline \multirow{3}{*}{$\mathbf{C r}$} & Measured concentration of impurity in solution $(\mu \mathrm{g} / \mathrm{ml})$ : & $<2.00 \mathrm{E}-03$ & $<2.00 \mathrm{E}-03$ & \\
\hline & Weight of impurity in sample group $(\mu \mathrm{g})$ : & $<0.08$ & $<0.08$ & \\
\hline & Total Weight of impurity detected $(\mu \mathrm{g})$ : & & & \multirow{3}{*}{ Mn } \\
\hline \multirow{3}{*}{ Mn } & Measured concentration of impurity in solution $(\mu \mathrm{g} / \mathrm{ml})$ : & $1.94 \mathrm{E}-03$ & $<1.91 \mathrm{E}-03$ & \\
\hline & Weight of impurity in sample group $(\mu \mathrm{g})$ : & 0.08 & $<0.07$ & \\
\hline & Total Weight of impurity detected $(\mu g)$ : & & & \\
\hline \multirow{3}{*}{ Co } & Measured concentration of impurity in solution $(\mu \mathrm{g} / \mathrm{ml})$ : & $<1.62 \mathrm{E}-03$ & $<1.62 \mathrm{E}-03$ & \multirow{2}{*}{ Co } \\
\hline & Weight of impurity in sample group $(\mu g)$ : & $<0.07$ & $<0.06$ & \\
\hline & Total Weight of impurity detected $(\mu \mathrm{g})$ : & & & \multirow[b]{3}{*}{$\mathbf{N i}$} \\
\hline \multirow{3}{*}{ Ni } & Measured concentration of impurity in solution $(\mu \mathrm{g} / \mathrm{ml})$ : & $<8.00 \mathrm{E}-03$ & $<8.00 \mathrm{E}-03$ & \\
\hline & Weight of impurity in sample group $(\mu \mathrm{g})$ : & $<0.33$ & $<0.31$ & \\
\hline & Total Weight of impurity detected $(\mu \mathrm{g})$ : & & & \multirow[b]{3}{*}{$\mathrm{Ca}$} \\
\hline \multirow{3}{*}{$\mathbf{C a}$} & Measured concentration of impurity in solution $(\mu \mathrm{g} / \mathrm{ml})$ : & $6.65 E-01$ & $2.40 \mathrm{E}-01$ & \\
\hline & Weight of impurity in sample group $(\mu \mathrm{g})$ : & 27.60 & 9.36 & \\
\hline & Total Weight of impurity detected $(\mu \mathrm{g})$ : & & & \\
\hline \multirow{3}{*}{ Al } & Measured concentration of impurity in solution $(\mu \mathrm{g} / \mathrm{ml})$ : & $6.96 \mathrm{E}-02$ & $1.69 \mathrm{E}-02$ & \multirow{2}{*}{ Al } \\
\hline & Weight of impurity in sample group $(\mu \mathrm{g})$ : & 2.89 & 0.66 & \\
\hline & Total Weight of impurity detected $(\mu \mathrm{g})$ : & & & \multirow{4}{*}{$\mathbf{T i}$} \\
\hline \multirow{3}{*}{$\mathbf{T i}$} & Measured concentration of impurity in solution $(\mu \mathrm{g} / \mathrm{ml})$ : & $<8.00 \mathrm{E}-03$ & $<8.00 \mathrm{E}-03$ & \\
\hline & Weight of impurity in sample group $(\mu \mathrm{g})$ : & $<0.33$ & $<0.31$ & \\
\hline & Total Weight of impurity detected $(\mu \mathrm{g})$ : & & & \\
\hline \multirow{3}{*}{$\mathbf{v}$} & Measured concentration of impurity in solution $(\mu \mathrm{g} / \mathrm{ml})$ : & $<2.00 \mathrm{E}-03$ & $<2.00 \mathrm{E}-03$ & \multirow{3}{*}{$\mathbf{v}$} \\
\hline & Weight of impurity in sample group $(\mu \mathrm{g})$ : & $<0.08$ & $<0.08$ & \\
\hline & Total Weight of impurity detected $(\mu \mathrm{g}):$ & & & \\
\hline
\end{tabular}

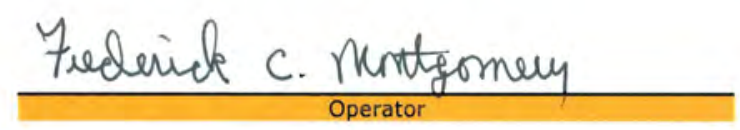

$9-(-20)^{\prime}$ 
Data Report Form DRF-44 Supplemental: Measurement of Impurities in Matrix Ring Blank Ash

\begin{tabular}{|c|c|}
\hline Procedure: & AGR-CHAR-DAM-44 Rev. 0 \\
\hline Operator: & Fred Montgomery \\
\hline Ring blank lot ID: & ARB-B1 \\
\hline Ring blank lot description: & Matrix Blend I with Hexion Durite SD-1708 resin \\
\hline Ring blank ID numbers: & Z026, Z015, Z014 \\
\hline DRF filename: & |Imc-agr|AGR\LeachBurnLeach|ARB-B1_DRF44R0.xlsx \\
\hline
\end{tabular}

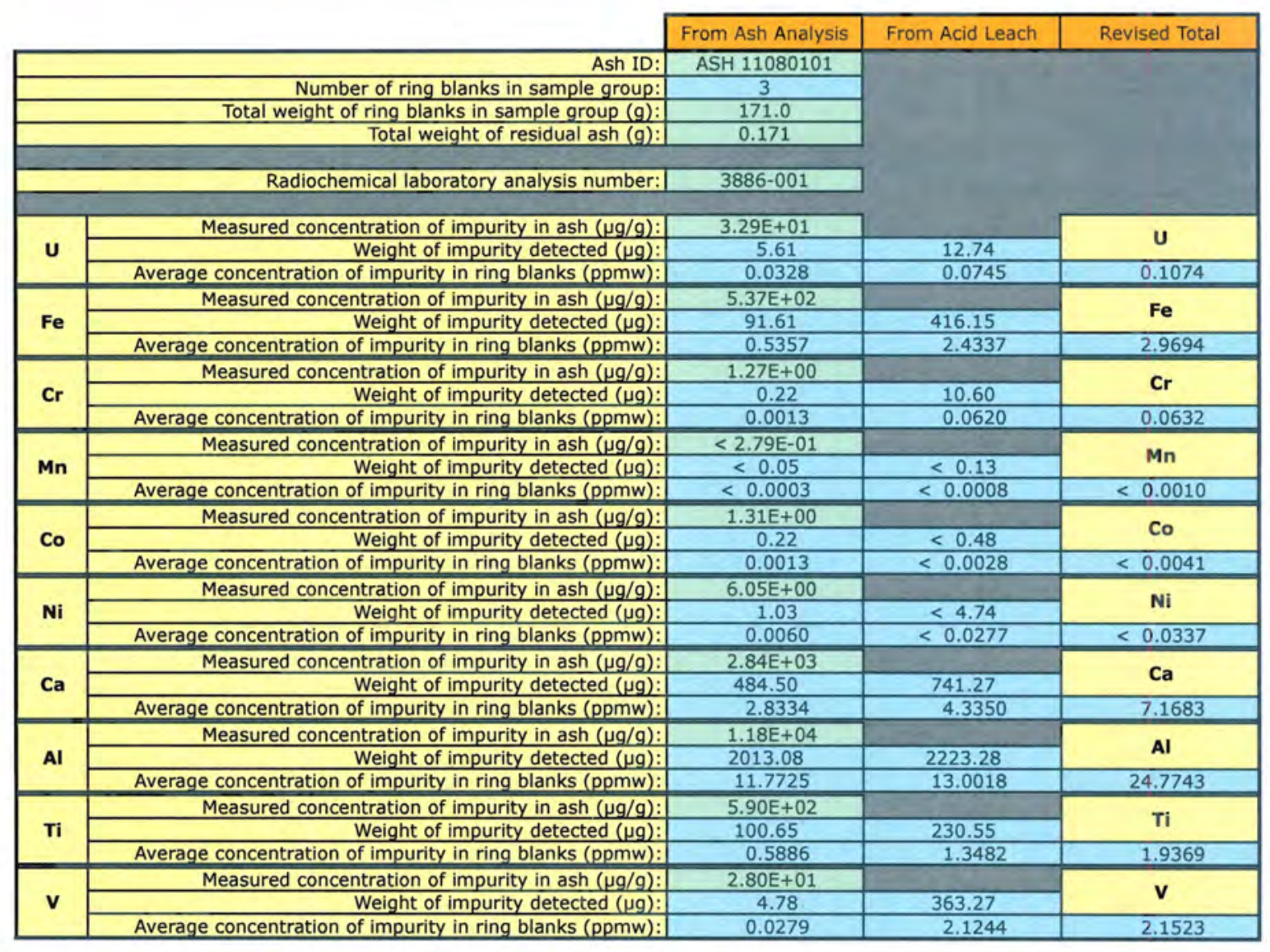

\section{Comments}

Additional ring blank impurities greater than about 1 ppmw detected in ash: 105 ppmw Si, 1.7 ppmw Ba, 1.6 ppmw Mg, 1.0 ppmw Zr. Of the $0.1706 \mathrm{~g}$ of ash residue, the amount that did not dissolve during the microwave digestion was $0.1276 \mathrm{~g}$.

Data checked by FCM against the official results of analyses for RMAL3886 on 8/25/2011.

\section{Frederick C. Mentgomeey}

$$
9-1-2011
$$


Data Report Form DRF-44 Supplemental: Measurement of Impurities in Matrix Ring Blank Ash

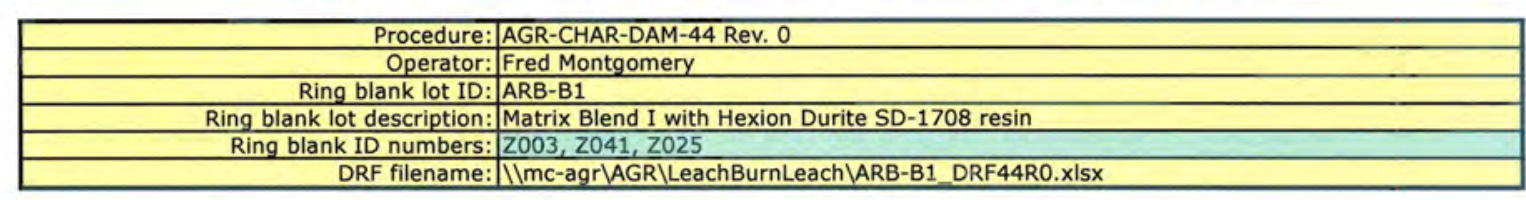

\begin{tabular}{|c|c|c|c|c|}
\hline \multirow{2}{*}{\multicolumn{2}{|c|}{ Ash ID: }} & From Ash Analysis & From Acid Leach & Revised Tota \\
\hline & & ASH 11080102 & & \\
\hline \multicolumn{2}{|r|}{ Number of ring blanks in sample group: } & 3 & & \\
\hline \multirow{2}{*}{\multicolumn{2}{|c|}{$\begin{array}{r}\text { Total weight of ring blanks in sample group }(\mathrm{g}) \text { : } \\
\text { Total weight of residual ash }(\mathrm{g}) \text { : }\end{array}$}} & 170.9 & & \\
\hline & & 0.159 & & \\
\hline \multicolumn{2}{|r|}{ Radiochemical laboratory analysis number: } & $3886-002$ & & \\
\hline & & & & \\
\hline \multirow{3}{*}{$\mathbf{u}$} & Measured concentration of impurity in ash $(\mu \mathrm{g} / \mathrm{g})$ : & $2.42 \mathrm{E}+01$ & & \multirow{2}{*}{ u } \\
\hline & Weight of impurity detected $(\mu \mathrm{g})$ : & 3.84 & 7.48 & \\
\hline & Average concentration of impurity in ring blanks (ppmw): & 0.0225 & 0.0438 & 0.0663 \\
\hline \multirow{3}{*}{$\mathbf{F e}$} & Measured concentration of impurity in ash $(\mu \mathrm{g} / \mathrm{g})$ : & $6.57 E+02$ & & \multirow{2}{*}{$\mathrm{Fe}$} \\
\hline & Weight of impurity detected $(\mu \mathrm{g})$ : & 104.33 & 415.24 & \\
\hline & Average concentration of impurity in ring blanks (ppmw): & 0.6104 & 2.4295 & 3.0399 \\
\hline \multirow{3}{*}{$\mathrm{Cr}$} & Measured concentration of impurity in ash $(\mu \mathrm{g} / \mathrm{g})$ : & $1.14 E+00$ & & \multirow{2}{*}{$\mathrm{Cr}$} \\
\hline & Weight of impurity detected $(\mu \mathrm{g})$ : & 0.18 & 8.16 & \\
\hline & Average concentration of impurity in ring blanks (ppmw): & 0.0011 & 0.0477 & 0.0488 \\
\hline \multirow{3}{*}{ Mn } & Measured concentration of impurity in ash $(\mu \mathrm{g} / \mathrm{g})$ : & $<3.00 \mathrm{E}-01$ & & \multirow{2}{*}{ Mn } \\
\hline & Weight of impurity detected $(\mu \mathrm{g})$ : & $<0.05$ & $<0.14$ & \\
\hline & Average concentration of impurity in ring blanks (ppmw): & $<0.0003$ & $<0.0008$ & $<0.0011$ \\
\hline \multirow{3}{*}{ Co } & Measured concentration of impurity in ash $(\mu \mathrm{g} / \mathrm{g})$ : & $1.45 E+00$ & & \multirow[b]{2}{*}{ Co } \\
\hline & Weight of impurity detected $(\mu \mathrm{g})$ : & 0.23 & $<0.45$ & \\
\hline & Average concentration of impurity in ring blanks ( $\mathrm{ppmw}$ ): & 0.0013 & $<0.0026$ & $<0.0040$ \\
\hline \multirow{3}{*}{$\mathbf{N i}$} & Measured concentration of impurity in ash $(\mu \mathrm{g} / \mathrm{g})$ : & $5.72 E+00$ & & \multirow{3}{*}{$\frac{\mathrm{Ni}}{0.337}$} \\
\hline & Weight of impurity detected $(\mu \mathrm{g})$ : & 0.91 & 4.85 & \\
\hline & Average concentration of impurity in ring blanks (ppmw): & 0.0053 & 0.0284 & \\
\hline \multirow{3}{*}{$\mathbf{C a}$} & Measured concentration of impurity in ash $(\mu \mathrm{g} / \mathrm{g})$ : & $3.00 \mathrm{E}+03$ & & \multirow{2}{*}{$\mathrm{Ca}$} \\
\hline & Weight of impurity detected $(\mu \mathrm{g})$ : & 476.40 & 772.84 & \\
\hline & Average concentration of impurity in ring blanks (ppmw): & 2.7873 & 4.5217 & 7.3090 \\
\hline \multirow{3}{*}{ Al } & Measured concentration of impurity in ash $(\mu \mathrm{g} / \mathrm{g})$ : & $1.17 E+04$ & & \multirow{2}{*}{ Al } \\
\hline & Weight of impurity detected $(\mu \mathrm{g})$ : & 1857.96 & 2358.16 & \\
\hline & Average concentration of impurity in ring blanks (ppmw): & 10.8704 & 13.7969 & 24.6673 \\
\hline \multirow{3}{*}{$\mathbf{T i}$} & Measured concentration of impurity in ash $(\mu \mathrm{g} / \mathrm{g})$ : & $6.26 \mathrm{E}+02$ & & \multirow{2}{*}{$\mathbf{T i}$} \\
\hline & Weight of impurity detected $(\mu \mathrm{g})$ : & 99.41 & 213.40 & \\
\hline & Average concentration of impurity in ring blanks (ppmw): & 0.5816 & 1.2486 & 1.8302 \\
\hline \multirow{3}{*}{$\mathbf{v}$} & Measured concentration of impurity in ash $(\mu \mathrm{g} / \mathrm{g})$ : & $3.46 \mathrm{E}+01$ & & \multirow[b]{2}{*}{ v } \\
\hline & Weight of impurity detected $(\mu \mathrm{g})$ : & 5.49 & 363.26 & \\
\hline & Average concentration of impurity in ring blanks ( $\mathrm{ppmw})$ : & 0.0321 & 2.1253 & 2.1575 \\
\hline
\end{tabular}

\section{Comments}

Additional ring blank impurities greater than about 1 ppmw detected in ash: 99 ppmw Si, 1.7 ppmw Ba, 1.7 ppmw Mg, 1.0 ppmw Zr. Of the $0.1588 \mathrm{~g}$ of ash residue, the amount that did not dissolve during the microwave digestion was $0.1239 \mathrm{~g}$. Data checked by FCM against the official results of analyses for RMAL3886 on 8/25/2011.

\section{Frederick C. Mnteomery}

$9-1-2011$

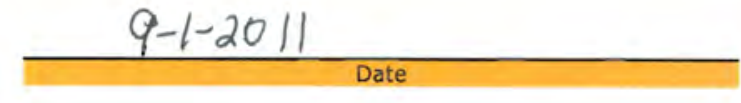


Data Report Form DRF-44 Supplemental: Measurement of Impurities in Matrix Ring Blank Ash

\begin{tabular}{|c|c|}
\hline Procedure: & AGR-CHAR-DAM-44 Rev. 0 \\
\hline Operator: & Fred Montgomery \\
\hline Ring blank lot ID: & ARB-B1 \\
\hline Ring blank lot description: & Matrix Blend I with Hexion Durite SD-1708 resin \\
\hline Ring blank ID numbers: & $\mathrm{Z} 035, \mathrm{Z} 027, \mathrm{ZO} 40$ \\
\hline DRF filename: & IImc-agr|AGR\LeachBurnLeach\ARB-B1_DRF44R0.xIsx \\
\hline
\end{tabular}

\begin{tabular}{|c|c|c|c|c|}
\hline & & From Ash Analysis & From Acid Leach & Revised Total \\
\hline & Ash ID: & ASH 11080103 & & \\
\hline & Number of ring blanks in sample group: & 3 & & \\
\hline & Total weight of ring blanks in sample group $(\mathrm{g})$ : & 171.5 & & \\
\hline & Total weight of residual ash $(\mathrm{g})$ : & 0.167 & & \\
\hline & Radiochemical laboratory analysis number: & $3886-003$ & & \\
\hline \multirow{3}{*}{ u } & Measured concentration of impurity in ash $(\mu \mathrm{g} / \mathrm{q})$ : & $2.97 E+01$ & & \multirow[b]{2}{*}{ u } \\
\hline & Weight of impurity detected $(\mu g)$ : & $\frac{2.975+01}{4.97}$ & 330.07 & \\
\hline & Average concentration of impurity in ring blanks (ppmw): & 0.0290 & 1.9252 & 1.9542 \\
\hline \multirow{3}{*}{$\mathbf{F e}$} & Measured concentration of impurity in ash $(\mu \mathrm{g} / \mathrm{g})$ : & $5.21 E+02$ & & \multirow{2}{*}{$\mathrm{Fe}$} \\
\hline & Weight of impurity detected $(\mu \mathrm{g})$ : & 87.22 & 415.51 & \\
\hline & Average concentration of impurity in ring blanks (ppmw): & 0.5087 & 2.4235 & 2.9322 \\
\hline \multirow{3}{*}{ Cr } & Measured concentration of impurity in ash $(\mu \mathrm{g} / \mathrm{g})$ : & $8.30 \mathrm{E}-01$ & & \multirow{2}{*}{$\mathrm{Cr}$} \\
\hline & Weight of impurity detected $(\mu \mathrm{g})$ : & 0.14 & 6.92 & \\
\hline & Average concentration of impurity in ring blanks (ppmw): & 0.0008 & 0.0404 & 0.0412 \\
\hline \multirow{3}{*}{ Mn } & Measured concentration of impurity in ash $(\mu \mathrm{g} / \mathrm{g})$ : & $<2.85 \mathrm{E}-01$ & & \multirow[b]{2}{*}{ Mn } \\
\hline & Weight of impurity detected $(\mu \mathrm{g})$ : & $<0.05$ & $<0.12$ & \\
\hline & Average concentration of impurity in ring blanks (ppmw): & $<0.0003$ & $<0.0007$ & $<0.0010$ \\
\hline \multirow{3}{*}{ Co } & Measured concentration of impurity in ash $(\mu \mathrm{g} / \mathrm{g})$ : & $1.21 \mathrm{E}+00$ & & \multirow[b]{2}{*}{ Co } \\
\hline & Weight of impurity detected $(\mu \mathrm{g})$ : & 0.20 & $<0.43$ & \\
\hline & Average concentration of impurity in ring blanks (ppmw): & 0.0012 & $<0.0025$ & $<0.0037$ \\
\hline \multirow{3}{*}{$\mathbf{N i}$} & Measured concentration of impurity in ash $(\mu \mathrm{g} / \mathrm{g})$ : & $4.71 E+00$ & & \multirow{2}{*}{$\mathrm{Ni}$} \\
\hline & Weight of impurity detected $(\mu \mathrm{g})$ : & 0.79 & $<4.43$ & \\
\hline & Average concentration of impurity in ring blanks (ppmw): & 0.0046 & $<0.0258$ & $<0.0304$ \\
\hline \multirow{3}{*}{$\mathbf{C a}$} & Measured concentration of impurity in ash $(\mu g / g)$ : & $2.89 \mathrm{E}+03$ & & \multirow{2}{*}{$\mathrm{Ca}$} \\
\hline & Weight of impurity detected $(\mu \mathrm{g})$ : & 483.79 & 733.18 & \\
\hline & Average concentration of impurity in ring blanks (ppmw): & 2.8217 & 4.2763 & 7.0980 \\
\hline \multirow{3}{*}{ Al } & Measured concentration of impurity in ash $(\mu \mathrm{g} / \mathrm{g})$ : & $1.12 \mathrm{E}+04$ & & \multirow{2}{*}{ Al } \\
\hline & Weight of impurity detected $(\mu \mathrm{g})$ : & 1874.88 & 2249.32 & \\
\hline & Average concentration of impurity in ring blanks (ppmw): & 10.9354 & 13.1193 & 24.0546 \\
\hline \multirow{3}{*}{$\mathbf{T i}$} & Measured concentration of impurity in ash $(\mu \mathrm{g} / \mathrm{g})$ : & $5.64 E+02$ & & \multirow{2}{*}{$\mathbf{T i}$} \\
\hline & Weight of impurity detected $(\mu g)$ : & 94.41 & 222.13 & \\
\hline & Average concentration of impurity in ring blanks (ppmw): & 0.5507 & 1.2956 & 1.8463 \\
\hline \multirow{3}{*}{$\mathbf{v}$} & Measured concentration of impurity in ash $(\mu \mathrm{g} / \mathrm{g})$ : & $3.21 E+01$ & & \multirow{2}{*}{$\mathbf{v}$} \\
\hline & Weight of impurity detected $(\mu \mathrm{g})$ : & 5.37 & 356.56 & \\
\hline & Average concentration of impurity in ring blanks (ppmw): & 0.0313 & 2.0796 & 2.1110 \\
\hline
\end{tabular}

\section{Comments}

Additional ring blank impurities greater than about 1 ppmw detected in ash: 100 ppmw Si, 1.8 ppmw Ba, 1.7 ppmw Mg, 0.6 ppmw Zr. Of the $0.1674 \mathrm{~g}$ of ash residue, the amount that did not dissolve during the microwave digestion was $0.1246 \mathrm{~g}$.

Data checked by FCM against the official results of analyses for RMAL 3886 on 8/25/2011.

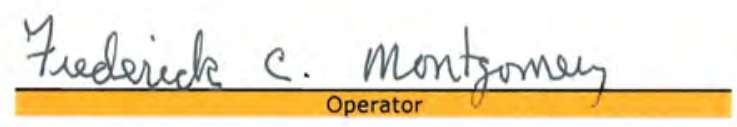

$$
9-1-2011
$$


Data Report Form DRF-44 Supplemental: Measurement of Impurities in Matrix Ring Blank Ash

\begin{tabular}{|c|c|}
\hline Procedure: & AGR-CHAR-DAM-44 Rev. 0 \\
\hline Operator: & Fred Montgomery \\
\hline Ring blank lot ID: & ARB-B1 \\
\hline Ring blank lot description: & Matrix Blend I with Hexion Durite SD-1708 resin \\
\hline Ring blank ID numbers: & $\mathrm{Z} 019, \mathrm{Z} 036, \mathrm{ZO} 044$ \\
\hline DRF filename: & IImc-agr|AGR\LeachBurnLeach|ARB-B1_DRF44R0.xIsx \\
\hline
\end{tabular}

\begin{tabular}{|c|c|c|c|c|}
\hline \multirow{2}{*}{\multicolumn{2}{|c|}{ Ash ID: }} & From Ash Analysis & From Acid Leach & Revised Total \\
\hline & & ASH 11080104 & & \\
\hline \multicolumn{2}{|r|}{ Number of ring blanks in sample group: } & 3 & & \\
\hline \multirow{2}{*}{\multicolumn{2}{|c|}{$\begin{array}{r}\text { Total weight of ring blanks in sample group }(g) \text { : } \\
\text { Total weight of residual ash }(g) \text { : }\end{array}$}} & 171.5 & & \\
\hline & & 0.160 & & \\
\hline \multicolumn{2}{|r|}{ Radiochemical laboratory analysis number: } & $3886-004$ & & \\
\hline & & & & \\
\hline \multirow{3}{*}{$\mathbf{u}$} & Measured concentration of impurity in ash $(\mu \mathrm{g} / \mathrm{g})$ : & $4.17 E+01$ & & \multirow{2}{*}{$u$} \\
\hline & Weight of impurity detected $(\mu \mathrm{g})$ : & 6.65 & 15.11 & \\
\hline & Average concentration of impurity in ring blanks (ppmw): & 0.0388 & 0.0881 & 0.1269 \\
\hline \multirow{3}{*}{$\mathrm{Fe}$} & Measured concentration of impurity in ash $(\mu \mathrm{g} / \mathrm{g})$ : & $5.57 E+02$ & & \multirow{2}{*}{$\mathrm{Fe}$} \\
\hline & Weight of impurity detected $(\mu \mathrm{g})$ : & 88.84 & 366.72 & \\
\hline & Average concentration of impurity in ring blanks (ppmw): & 0.5179 & 2.1379 & 2.6558 \\
\hline \multirow{3}{*}{$\mathrm{Cr}$} & Measured concentration of impurity in ash $(\mu \mathrm{g} / \mathrm{g})$ : & $8.38 \mathrm{E}-01$ & & \multirow{2}{*}{$\mathrm{Cr}$} \\
\hline & Weight of impurity detected $(\mu \mathrm{g})$ : & 0.13 & 7.63 & \\
\hline & Average concentration of impurity in ring blanks (ppmw): & 0.0008 & 0.0445 & 0.0452 \\
\hline \multirow{3}{*}{ Mn } & Measured concentration of impurity in ash $(\mu \mathrm{g} / \mathrm{g})$ : & $<2.99 \mathrm{E}-01$ & & \multirow[b]{2}{*}{ Mn } \\
\hline & Weight of impurity detected $(\mu \mathrm{g})$ : & $<0.05$ & $<0.15$ & \\
\hline & Average concentration of impurity in ring blanks (ppmw): & $<0.0003$ & $<0.0009$ & $<0.0011$ \\
\hline \multirow{3}{*}{ Co } & Measured concentration of impurity in ash $(\mu \mathrm{g} / \mathrm{g})$ : & $1.30 \mathrm{E}+00$ & & \multirow[b]{2}{*}{ Co } \\
\hline & Weight of impurity detected $(\mu \mathrm{g})$ : & 0.21 & $<0.40$ & \\
\hline & Average concentration of impurity in ring blanks (ppmw): & 0.0012 & $<0.0023$ & $<0.0036$ \\
\hline \multirow{3}{*}{$\mathbf{N i}$} & Measured concentration of impurity in ash $(\mu \mathrm{g} / \mathrm{g})$ : & $6.68 \mathrm{E}+00$ & & \multirow{2}{*}{$\mathbf{N i}$} \\
\hline & Weight of impurity detected $(\mu \mathrm{g})$ : & 1.07 & $<4.65$ & \\
\hline & Average concentration of impurity in ring blanks (ppmw): & 0.0062 & $<0.0271$ & $<0.0333$ \\
\hline \multirow{3}{*}{$\mathbf{C a}$} & Measured concentration of impurity in ash $(\mu \mathrm{g} / \mathrm{g})$ : & $3.33 E+03$ & & \multirow{2}{*}{$\mathrm{Ca}$} \\
\hline & Weight of impurity detected $(\mu \mathrm{g})$ : & 531.14 & 770.82 & \\
\hline & Average concentration of impurity in ring blanks (ppmw): & 3.096 & 4.494 & 7.590 \\
\hline \multirow{3}{*}{ Al } & Measured concentration of impurity in ash $(\mu \mathrm{g} / \mathrm{g})$ : & $1.30 \mathrm{E}+04$ & & \multirow{2}{*}{ Al } \\
\hline & Weight of impurity detected $(\mu \mathrm{g})$ : & 2073.50 & 2207.72 & \\
\hline & Average concentration of impurity in ring blanks (ppmw): & 12.0879 & 12.8703 & 24.9582 \\
\hline \multirow{3}{*}{$\mathbf{T i}$} & Measured concentration of impurity in ash $(\mu \mathrm{g} / \mathrm{q})$ : & $5.45 \mathrm{E}+02$ & & \multirow{2}{*}{$\pi i$} \\
\hline & Weight of impurity detected $(\mu \mathrm{g})$ : & 86.93 & 218.73 & \\
\hline & Average concentration of impurity in ring blanks (ppmw): & 0.5068 & 1.2752 & 1.7819 \\
\hline \multirow{3}{*}{$\mathbf{v}$} & Measured concentration of impurity in ash $(\mu \mathrm{g} / \mathrm{q})$ : & $2.95 E+01$ & & \multirow{2}{*}{$\mathbf{v}$} \\
\hline & Weight of impurity detected $(\mu \mathrm{g})$ : & 4.71 & 356.11 & \\
\hline & Average concentration of impurity in ring blanks (ppmw): & 0.0274 & 2.0760 & 2.1034 \\
\hline
\end{tabular}

\section{Comments}

Additional ring blank impurities greater than about 1 ppmw detected in ash: 100 ppmw Si, 1.9 ppmw Ba, 1.7 ppmw Mg, 0.5 ppmw Zr. Of the $0.1595 \mathrm{~g}$ of ash residue, the amount that did not dissolve during the microwave digestion was $0.1160 \mathrm{~g}$.

Data checked by FCM against the official results of analyses for RMAL3886 on 8/25/2011.

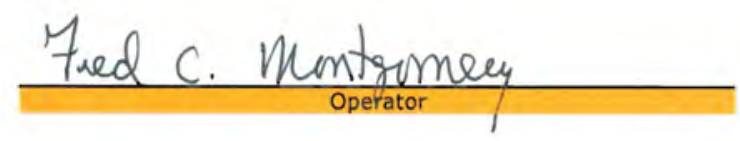

$9-1-2011$ Date 
Data Report Form DRF-44 Supplemental: Measurement of Impurities in Matrix Ring Blank Ash

\begin{tabular}{|c|c|}
\hline Procedure: & AGR-CHAR-DAM-44 Rev. 0 \\
\hline Operator: & Fred Montgomery \\
\hline Ring blank lot ID: & ARB-B1 \\
\hline Ring blank lot description: & Matrix Blend I with Hexion Durite SD-1708 resin \\
\hline Ring blank ID numbers: & Blank \\
\hline DRF filename: & $44 R 0 . x 15 x$ \\
\hline
\end{tabular}

\begin{tabular}{|c|c|c|c|c|}
\hline \multirow{2}{*}{\multicolumn{2}{|c|}{ Ash ID: }} & From Ash Analysis & From Acid Leach & Revised Total \\
\hline & & ASH 11080105 & & \\
\hline \multirow{2}{*}{\multicolumn{2}{|c|}{$\begin{array}{l}\text { Number of ring blanks in sample group: } \\
\text { Total weight of ring blanks in sample group }(\mathrm{g}) \text { : }\end{array}$}} & 1 & & \\
\hline & & & & \\
\hline \multicolumn{5}{|c|}{ Total weight of residual ash (g): } \\
\hline \multicolumn{2}{|r|}{ Radiochemical laboratory analysis number: } & $3886-005$ & & \\
\hline \multirow{3}{*}{$\mathbf{u}$} & Measured concentration of impurity in ash $(\mu \mathrm{g} / \mathrm{g})$ : & & & \multirow[b]{2}{*}{ u } \\
\hline & Weight of impurity detected $(\mu g)$ : & $<5.00 \mathrm{E}-03$ & 0.22 & \\
\hline & Total Weight of impurity detected $(\mu \mathrm{g})$ : & & & \multirow[b]{3}{*}{$\mathrm{Fe}$} \\
\hline \multirow{3}{*}{$\mathbf{F e}$} & Measured concentration of impurity in ash $(\mu \mathrm{g} / \mathrm{g})$ : & & & \\
\hline & Weight of impurity detected $(\mu g)$ : & $<1.03 E+00$ & $<5.40$ & \\
\hline & Total Weight of impurity detected $(\mu \mathrm{g})$ : & & & \multirow[b]{3}{*}{$\mathrm{Cr}$} \\
\hline \multirow{3}{*}{$\mathbf{C r}$} & Measured concentration of impurity in ash $(\mu \mathrm{g} / \mathrm{g})$ : & & & \\
\hline & Weight of impurity detected $(\mu \mathrm{g})$ : & $<5.00 \mathrm{E}-02$ & $<0.16$ & \\
\hline & Total Weight of impurity detected $(\mu \mathrm{g})$ : & & & \\
\hline \multirow{3}{*}{ Mn } & Measured concentration of impurity in ash $(\mu \mathrm{g} / \mathrm{g})$ : & & & \multirow[b]{2}{*}{ Mn } \\
\hline & Weight of impurity detected $(\mu \mathrm{g})$ : & $<4.77 \mathrm{E}-02$ & $<0.16$ & \\
\hline & Total Weight of impurity detected $(\mu \mathrm{g})$ : & & & \multirow{4}{*}{ Co } \\
\hline \multirow{3}{*}{ Co } & Measured concentration of impurity in ash $(\mu \mathrm{g} / \mathrm{g})$ : & & & \\
\hline & Weight of impurity detected $(\mu \mathrm{g})$ : & $<4.06 \mathrm{E}-02$ & $<0.13$ & \\
\hline & Total Weight of impurity detected $(\mu \mathrm{g})$ : & & & \\
\hline \multirow{3}{*}{$\mathbf{N i}$} & Measured concentration of impurity in ash $(\mu \mathrm{g} / \mathrm{g})$ : & & & \multirow{3}{*}{ Ni } \\
\hline & Weight of impurity detected $(\mu \mathrm{g})$ : & $<2.00 \mathrm{E}-01$ & $<0.64$ & \\
\hline & Total Weight of impurity detected $(\mu \mathrm{g})$ : & & & \\
\hline \multirow{3}{*}{$\mathbf{C a}$} & Measured concentration of impurity in ash $(\mu \mathrm{g} / \mathrm{g})$ : & & & \multirow{3}{*}{$\mathrm{Ca}$} \\
\hline & Weight of impurity detected $(\mu \mathrm{g})$ : & $2.50 E+00$ & 36.96 & \\
\hline & Total Weight of impurity detected $(\mu \mathrm{g})$ : & & & \\
\hline \multirow{3}{*}{ Al } & Measured concentration of impurity in ash $(\mu \mathrm{g} / \mathrm{g})$ : & & & \multirow{2}{*}{ Al } \\
\hline & Weight of impurity detected $(\mu \mathrm{g})$ : & $1.28 \mathrm{E}+00$ & 3.55 & \\
\hline & Total Weight of impurity detected $(\mu \mathrm{g})$ : & & & \\
\hline \multirow{3}{*}{$\mathbf{T i}$} & Measured concentration of impurity in ash $(\mu \mathrm{g} / \mathrm{g})$ : & & & \multirow{3}{*}{$\mathbf{T i}$} \\
\hline & Weight of impurity detected $(\mu g)$ : & $<2.00 \mathrm{E}-01$ & $<0.64$ & \\
\hline & Total Weight of impurity detected $(\mu \mathrm{g})$ : & & & \\
\hline \multirow{3}{*}{$\mathbf{v}$} & Measured concentration of impurity in ash $(\mu \mathrm{g} / \mathrm{g})$ : & & & \multirow{3}{*}{$\mathbf{v}$} \\
\hline & Weight of impurity detected $(\mu g)$ : & $<5.00 \mathrm{E}-02$ & $<0.16$ & \\
\hline & Total Weight of impurity detected $(\mu \mathrm{g})$ : & & & \\
\hline
\end{tabular}

\section{Ziederick C. Montyomeey}

$$
9-1-2011
$$




\section{Appendix A: Non-Conformance Report for Matrix Density}

The following page is a copy of the non-conformance report NCR-X-AGR-11-01. This reports that 19 ring blanks from the ARB-B1 ring blank set had an average density slightly above the specified limit of $1.80 \mathrm{~g} / \mathrm{cm}^{3}$. These ring blanks were used for destructive impurity analysis or retained at ORNL and the 30 shipped to INL were within the specified density limits. 


\section{ORNL NONCONFORMANCE REPORT (NCR)}

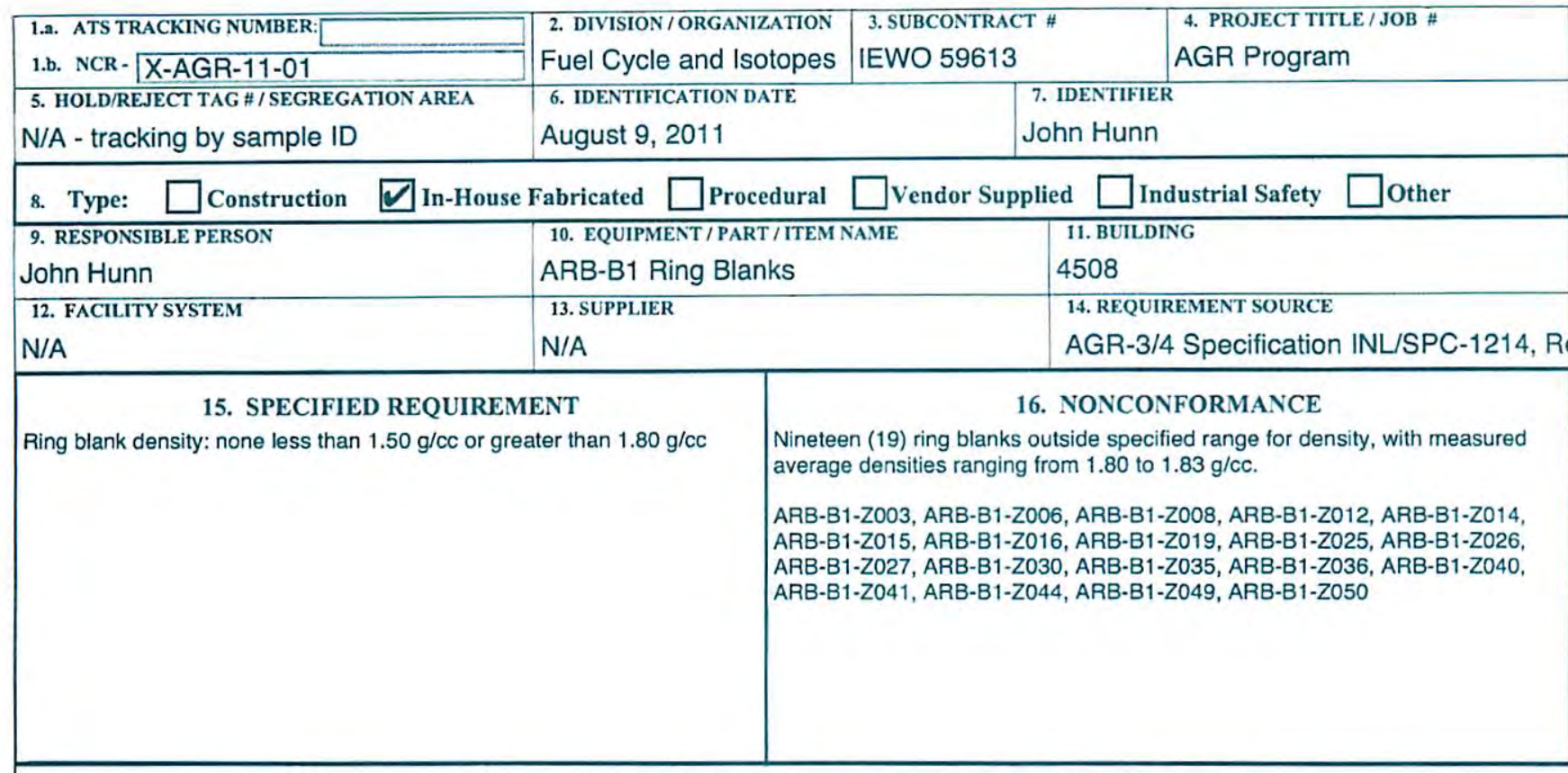

\section{EVALUATION, REMEDIAL ACTION, AND TECHNICAL JUSTIFICATION}

Ring blanks were fabricated according to approved and tested procedure. Target density of $1.75 \mathrm{~g} / \mathrm{cc}$ was too close to the upper specified limit to produce $100 \%$ of the ring blanks within the specified range. The main contributing factor was that the existing manual hydraulic press offered insufficient control on final length of ring blank. The insufficient nature of this hydraulic press had been previously noted by compacting expert and an electric servomotor press capable of more reliable control of compact length has been acquired for production of fuel compacts. However, this press could not be used for ring blanks because the required compacting pressure was beyond its limit. Acquisition of electric servomotor press with higher pressure load cells was not warranted for this work.

Recommended disposition is to use the nonconforming ring blanks for destructive impurity analysis and only ship conforming ring blanks to INL for machining into matrix rings that may be used in the AGR-3/4 irradiation test. A total of 50 ring blanks were produced, so there are sufficient conforming ring blanks to ship the full complement of 30 requested. Nonconformance in density will not affect validity of impurity analysis.

18. SUPPLIER PROPOSED DISPOSITION

SIGNATURE/DATE John Hunn, ORNL AGR Project Manager

\section{NONCONFORMANCE DISPOSITION}

$\square$ Accept/Use-As-Is $\square$ Approved for Alternate Use $\square$ Repair to Useable Condition $\square$ Rework to Spec. $\square$ Return to Vendor $\square$ Scrap

\begin{tabular}{l|l}
\hline 20. SUBJECT MATTER EXPERT, DATE & $\begin{array}{l}\text { 21. RESPONSIBLE PERSON, DATE } \\
\text { John Hunn } \\
\text { Jahn Hunn }\end{array}$ \\
\hline David Petti
\end{tabular}

23. DESIGN DRAWINGS, SPECS, OR PROCEDURE CHANGES? $\square$ Yes If yes, list below:

DESIGN AUTHORITY OR SYSTEM ENG., DATE. N/A

25. PAAA OFFICE SCREENING? $\square$ Yes $\square$ No

SIGNATURE,DATE
26. $\square$ actual $\square$ estimated cost

No additional cost associated with this disposition

REMEDIAL ACTION COMPLETION

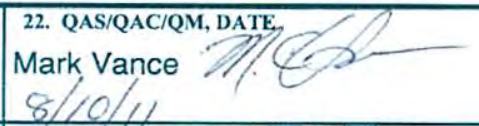

24. USQD REQUIRED? $\square$ Yes $\boldsymbol{\square}$ No

SAFETY ANALYST, DATE N/A 27. PROBABLE CAUSE CODE 


\section{Appendix B: Non-Conformance Report for Al Content}

The following page is a copy of the non-conformance report NCR-X-AGR-11-02. This reports that the average Al impurity content (24.6 ppmw) for the ARB-B1 ring blank set was above the specified limit of $\leq 20 \mathrm{ppmw}$. The disposition for this non-conformance was to accept for use. 


\section{ORNL NONCONFORMANCE REPORT (NCR)}

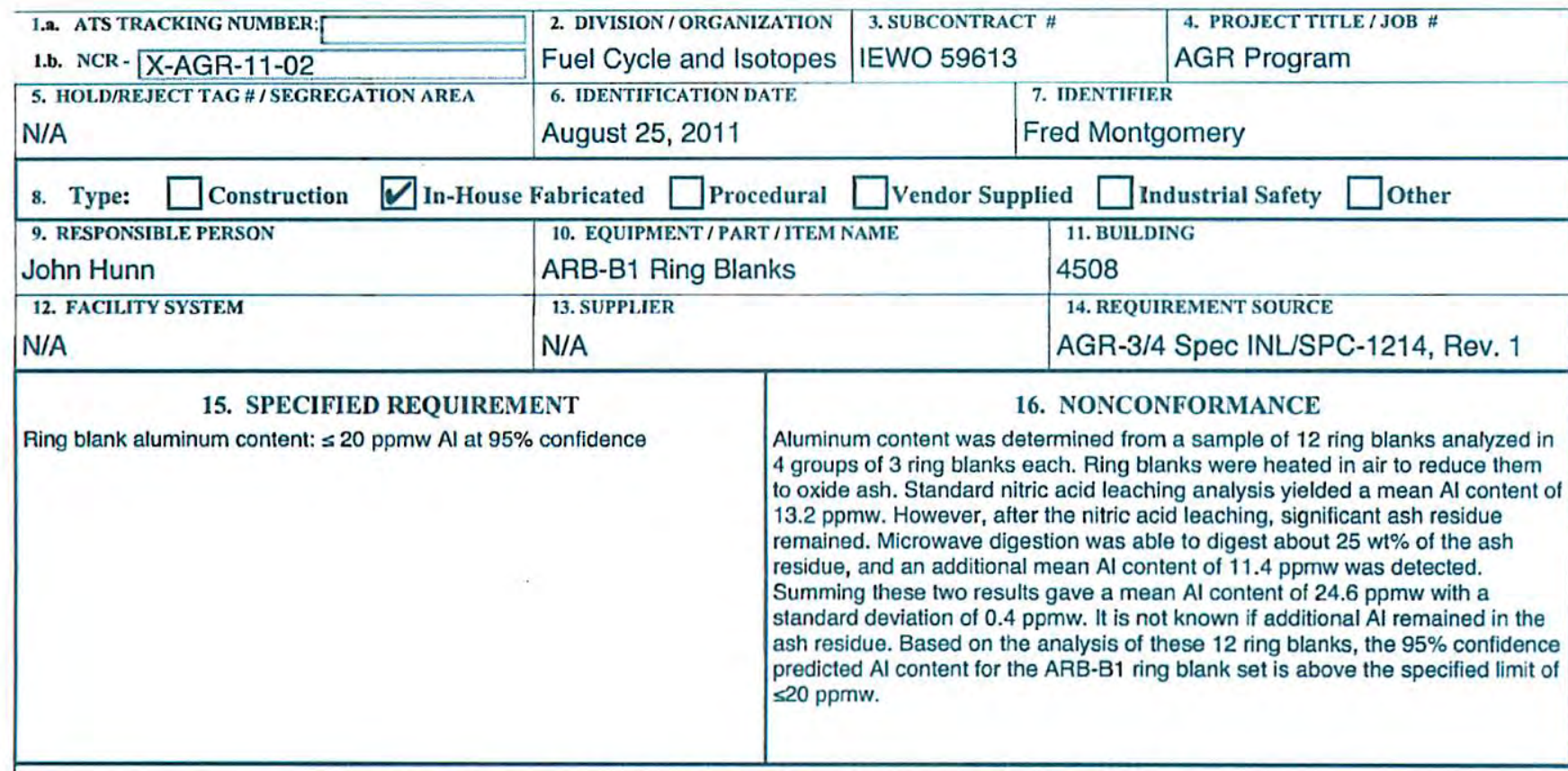

\section{EVALUATION, REMEDIAL ACTION, AND TECHNICAL JUSTIFICATION}

Asbury Graphite Mills RD 13371 natural graphite used for AGR-1, AGR-2, and AGR-3/4 compacts, and the RDKRS ring blanks was chosen based on several characteristics including low impurities and low residual ash. Asbury Graphite Mills RD 3482 natural graphite chosen for compact scale-up and used in the ARB-B1 ring blanks was a similar low impurity graphite, but was notably higher in $\mathrm{Al}(3.5 \mathrm{x}), \mathrm{Fe}(2.9 \mathrm{x})$, and $\mathrm{Si}(2.7 \mathrm{x})$. The resin used for ARB-B1 ring blanks was also higher in $\mathrm{Al}$ and $\mathrm{Fe}$. Ash residue was observed after hot nitric acid leaching of both the RDKRS and ARB-B1 ring blank samples. However, there was about 2.5 times more residual ash after nitric acid leaching of the ARB-B1 ring blanks. This increase in ash residue is thought to be due to the higher Si content, because SiO2 does not dissolve in nitric acid. Microwave digestion consumed most of the residual ash from the RDKRS ring blanks, but did not completely digest the ARB-B1 residual ash (this may have been due to the greater volume of ash in the digestion ampule).

Ring blanks were heat treated at $1800^{\circ} \mathrm{C}$ to reduce the impurity content. Mean Al content determined from nitric acid leaching and microwave digestion of the RDKRS ring blanks was $1.33 \mathrm{ppmw}$ with a standard deviation of $0.13 \mathrm{ppmw}$. This was about $4.5 \mathrm{x}$ lower than the sum of the Al content in the starting materials. Aluminum content was apparently unreduced by heat treatment of the ARB-B1 ring blanks. This may have been due to a lower permeability in the ARB-B1 ring blanks related to the higher density and different resin. The starting Al impurity content of the ARB-B1 graphite/resin matrix blend was too high to produce ring blanks that would pass the specification without impurity reduction during fabrication.

The specification for a maximum Al content of $\leq 20 \mathrm{ppmw}$ Al at $95 \%$ confidence is a conservative value. It is not expected that the observed Al content in the ARB-B1 ring blanks will affect the AGR-3/4 irradiation experiment. All other specified impurities were well below the specified limits.

18. SUPPLIER PROPOSED DISPOSITION
SIGNATURE/DATE John Hunn, ORNL AGR Project Manager $\mathrm{fuhm}$ thm 9-9-11

\section{NONCONFORMANCE DISPOSITION}

Accept/Use-As-Is $\square$ Approved for Alternate Use $\square$ Repair to Useable Condition $\square$ Rework to Spec. $\square$ Return to Vendor $\square$ Scrap

\begin{tabular}{l|l|l}
\hline 20. SUBJECT MATTER EXPERT, DATE & $\begin{array}{l}\text { 21. RESPONSIBLE PERSON, DATE } \\
\text { John Hunn } \\
\text { John Hunn }\end{array}$ Whid Petti
\end{tabular}

23. DESIGN DRAWINGS, SPECS, OR PROCEDURE CHANGES? $\square$ Yes If yes, list below: $\square$ No

DESIGN AUTHORITY OR SYSTEM ENG., DATE N/A

25. PAAA OFFICE SCREENING? $\square$ Yes $\square$ No

SIGNATURE,DATE

\begin{tabular}{|l|c|}
\hline 26. & 27. PROBABLE CAUSE CODE \\
No additional cost associated with this disposition & 4C \\
\hline
\end{tabular}

REMEDIAL ACTION COMPLETION
29. TARGET DATE

N/A
30. DATE CLOSED

N/A 


\section{Appendix C: Non-Conformance Report for U Contamination}

The following page is a copy of the non-conformance report NCR-X-AGR-11-03. This documents that one of the burn-leach samples from the ARB-B1 ring blank set analyzed for $U$ contamination had an abnormally high value $(1.95 \mathrm{ppmw})$, which was above the specified limit of $\leq 0.5 \mathrm{ppmw}$. The disposition for this non-conformance was to accept for use. Following the non-conformance report is a discussion of additional analysis performed in response to the observed anomaly. 


\section{ORNL NONCONFORMANCE REPORT (NCR)}

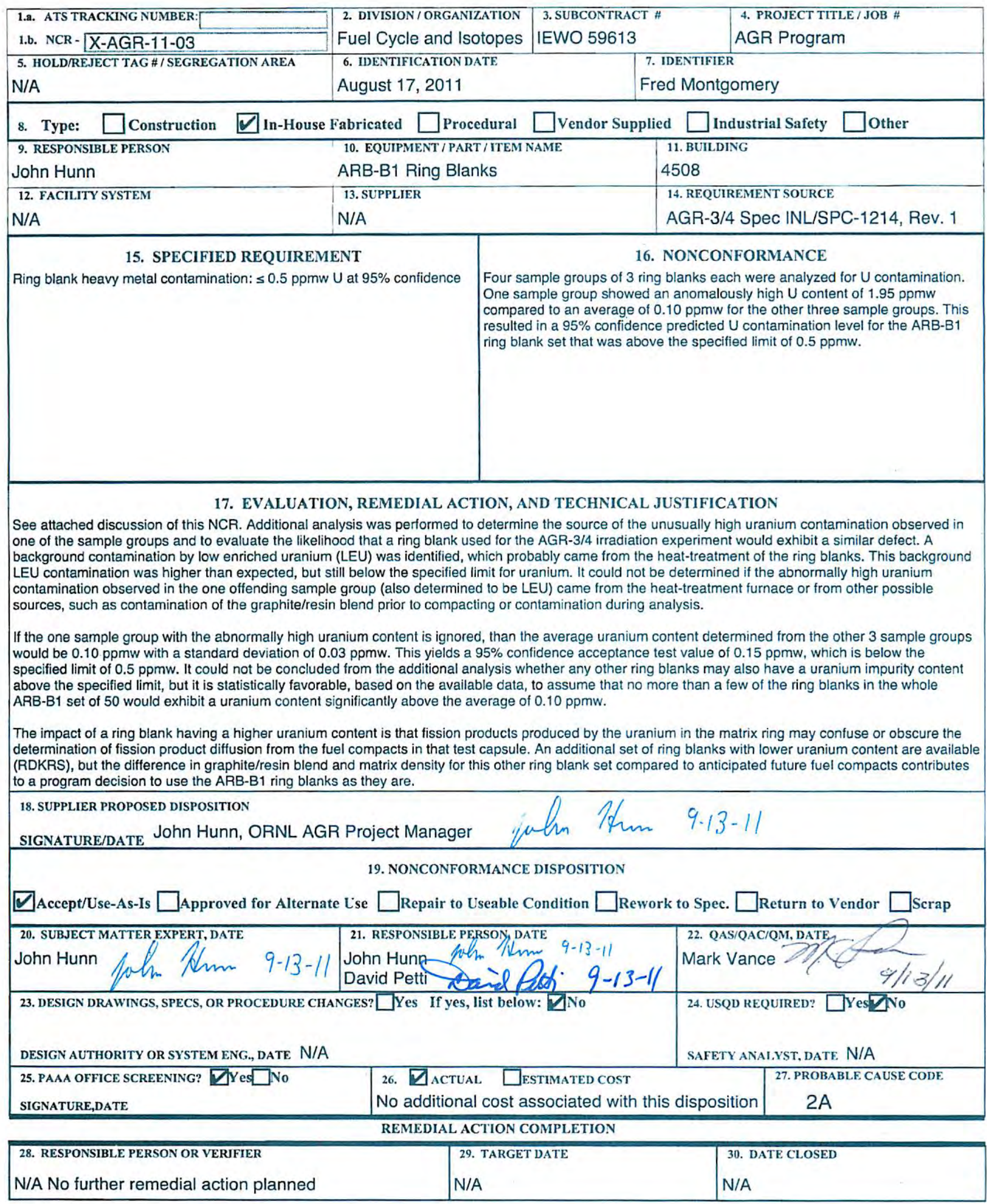




\section{Discussion of NCR-AGR-11-03}

The product inspection plan for AGR-3/4 matrix ring blanks, AGR-CHAR-PIP-20R1, specified burn-leach analysis of four samples of 3 ring blanks each, for a total sampling of 12 ring blanks analyzed out of the 50 produced for the ARB-B1 ring blank set. Burn-leach analysis was performed according to data acquisition method AGR-CHAR-DAM-44R0. Ring blanks were burned in air to reduce them to oxide ash. The ash was analyzed for selected metal contamination by leaching with boiling nitric acid for 24 hours, followed by a second 24 hour boiling nitric acid leach. After the standard burn-leach analysis, a significant quantity of ash residue remained. This ash residue was further analyzed by microwave-enhanced acid digestion and the results added to the results from the standard nitric acid leach. Table 10 shows a summary of the results for uranium.

Table 10. Results of uranium impurity analysis for ARB-B1 ring blanks

\begin{tabular}{|l|c|c|c|c|c|c|c|c|}
\hline \multirow{2}{*}{ Ring Blank IDs } & \multicolumn{2}{|c|}{ First Leach } & \multicolumn{2}{c|}{ Second Leach } & \multicolumn{2}{c|}{ Microwave Digestion } & \multicolumn{2}{c|}{ Total } \\
\cline { 2 - 9 } & $\mu \mathrm{g}$ & $\mathrm{ppmw}$ & $\mu \mathrm{g}$ & $\mathrm{ppmw}$ & $\mu \mathrm{g}$ & $\mathrm{ppmw}$ & $\mu \mathrm{g}$ & $\mathrm{ppmw}$ \\
\hline \hline Z026,Z015,Z014 & 12.12 & 0.071 & 0.62 & 0.004 & 5.61 & 0.033 & 18.35 & 0.107 \\
Z003,Z041,Z025 & 7.08 & 0.041 & 0.40 & 0.002 & 3.84 & 0.023 & 11.32 & 0.066 \\
Z035,Z027,Z040 & 319.80 & 1.865 & 10.27 & 0.060 & 4.97 & 0.029 & 335.04 & 1.954 \\
Z019,Z036,Z044 & 14.27 & 0.083 & 0.85 & 0.005 & 6.65 & 0.039 & 21.76 & 0.127 \\
\hline
\end{tabular}

The third set of ring blanks (ARB-B1-Z035, -Z027, - Z040) showed an unusually high uranium content, 20 times higher than the average of the other 3 sets. The leach solutions for this set were re-analyzed and this result was confirmed. The second leach in the burn-leach analysis for this set was also abnormally high, which further confirms that there was a real U impurity in the third analyzed set. Note that it can not be determined whether the unusually high U content was isolated in a single ring blank or distributed between the 3 ring blanks in the sample. Analysis of the U-235 ratio indicated that the source of the impurity was $19.7 \%$ enriched material, which should rule out the natural graphite as the source of the impurity and suggests contamination from the $19.7 \%$ enriched AGR-3/4 fuel fabricated prior to the ring blank fabrication. Three possible sources of the observed U contamination were considered: 1) perhaps a fuel particle got picked up and mixed in with the ring blank matrix blend during cold slugging and regranulation prior to pressing; 2) perhaps contamination was transferred to the ring blanks during heat-treatment; 3) perhaps a particle got into the burn-leach vessel during analysis.

\section{1) Consideration of the possibility that a fuel particle got picked up and mixed in with the ring blank matrix blend during cold slugging and re-granulation prior to pressing.}

The cold slugging and re-granulation process described in Section 2 was done in the same hood used for AGR-3/4 overcoating. The amount of uranium in the sample was equivalent to what is contained in 1.4 AGR-3/4 kernels. This suggests the possibility that one ring blank was contaminated with one or two fuel particles. However, it is unusual for burn-leach detection of exposed fuel kernels to yield values which vary more than $10 \%$ from a whole number of particles. 
If discreet particle contamination was the source of the observed uranium contamination then it may have been an isolated event. If other blanks were contaminated in this way, the fuel particles should be visible by imaging the ring blanks with $\mathrm{x}$-ray.

X-ray imaging was performed on the 8 ring blanks retained at ORNL and the 30 ring blanks shipped to INL. Three ring blanks were identified to contain fragments of material with higher density then the graphite matrix. Figure 6 shows ARB-B1-Z034. Note that the edges of the ring blanks are not visible in this image, because the x-ray imaging conditions were chosen to provide maximum contrast for the dense fragment (marked by an arrow). The dark lines perpendicular to the axis of the cylinder are low density planes or fissures in the matrix material. These planes are cupped toward the bottom of the cylinder. This is probably related to the way the ring blanks form in the die. Pressure is applied from the top and material is pushed to the bottom of the die with some drag along the walls.

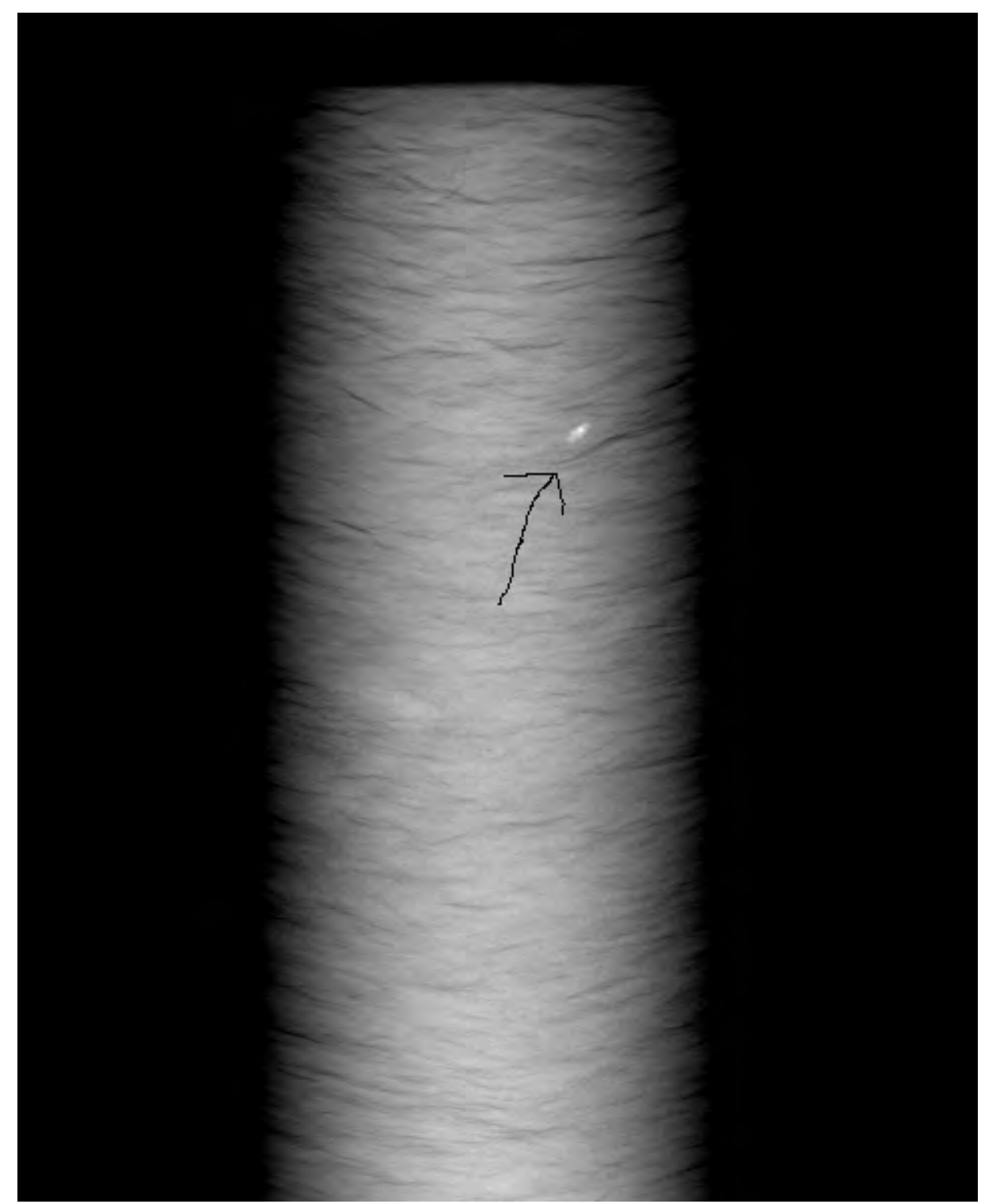

Figure 6. Dense inclusions in ring blank ARB-B1-Z034 shipped to INL. 
Figure 7 and Figure 8 show ARB-B1-Z006 and ARB-B1-Z050, where the ring blanks in the second image were rotated $45^{\circ}$ from their initial position. The spots in the image associated with high density fragments are marked by an arrow. Some bright spots may appear on some images due to dust on the negative scanner or some other anomaly. The ring blanks were imaged several times so that these artifacts could be eliminated. A high density fragment can be seen near the crack at the bottom of ARB-B1-Z006. This bright spot in the X-ray image moved laterally when the ring blank was rotated. The fragment in ARB-B1-Z050 seemed to stay in the same position on the x-ray image when rotated by 45 degrees. However, close examination revealed that the orientation of the fragment changed by $180^{\circ}$ after rotation, indicating that the fragment moved from above the midplane to below the midplane without significantly changing it's apparent lateral position.

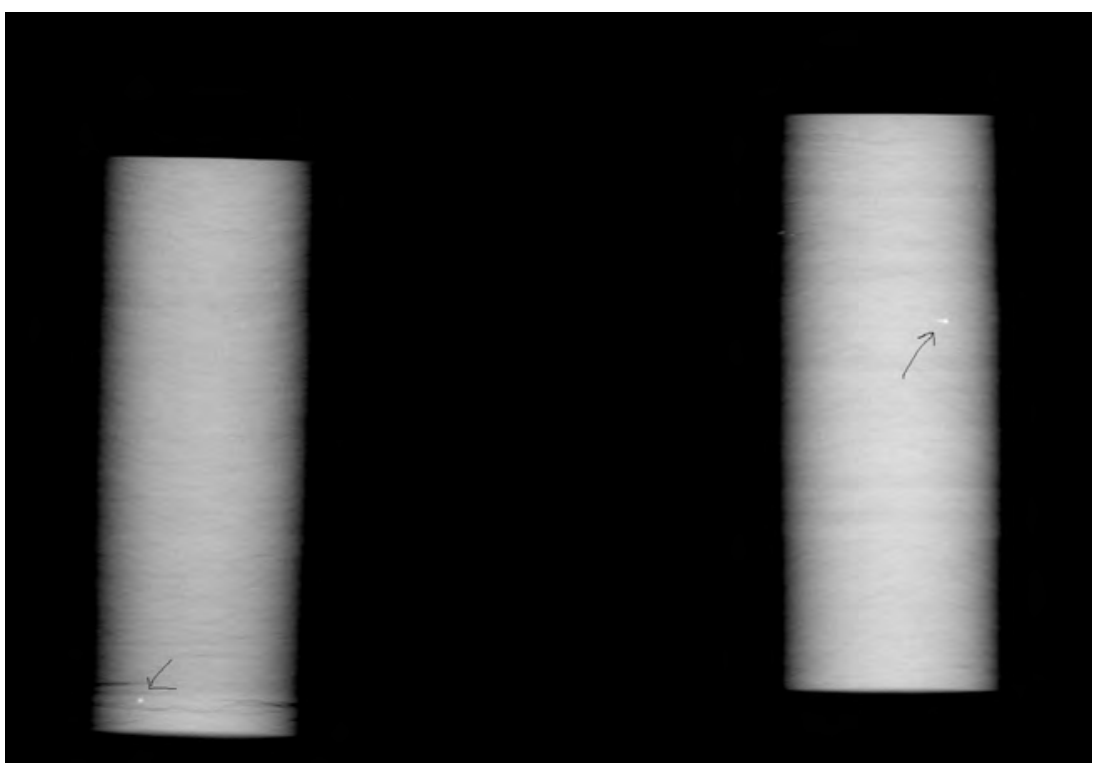

Figure 7. Higher density inclusions in ORNL archive ring blanks ARB-B1-Z006 (left) and ARB-B1-Z050 (right).

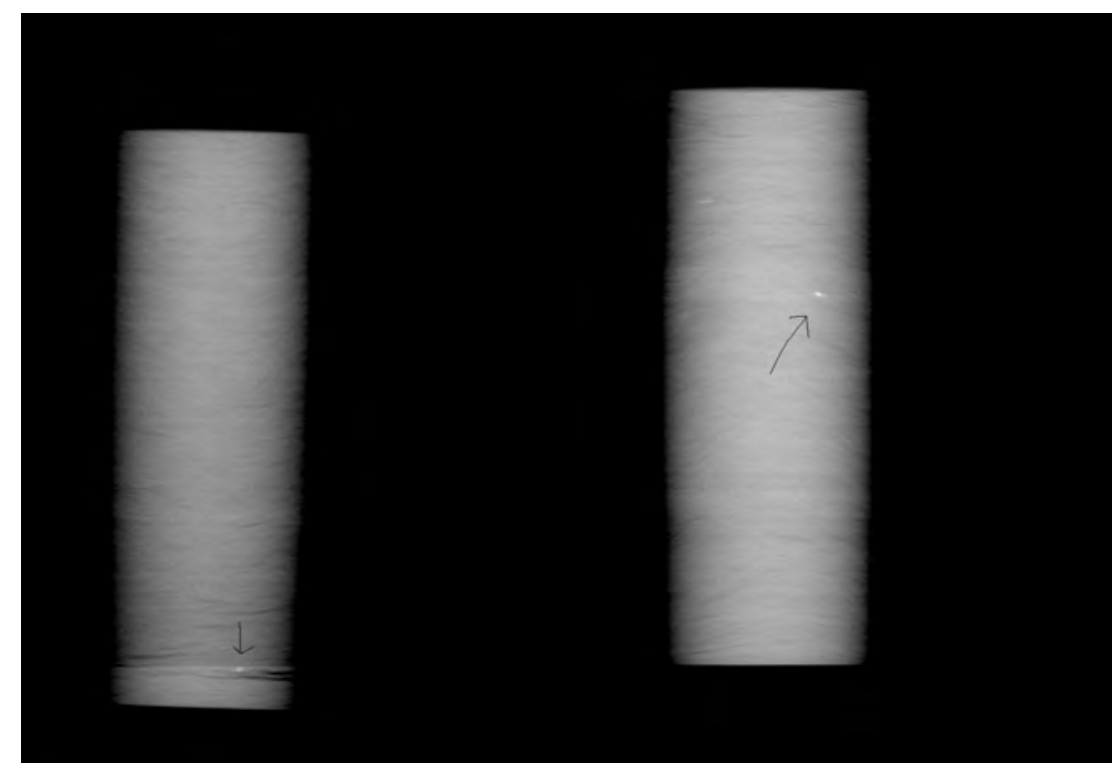

Figure 8. Same as Figure 7, but each cylinder has been rotated 45 degrees. 
A higher resolution x-ray image of the fragment in ARB-B1-Z006 is shown in Figure 9. This image shows that the fragment was not spherical as would be expected if it was a fuel kernel. With help from high-resolution $\mathrm{x}$-ray imaging, the fragment was exposed by grinding away the matrix carbon. Figure 10 shows a back-scattered electron image of the exposed region. Energy dispersive $\mathrm{x}$-ray spectroscopy (EDS) identified the impurity as mostly Fe, with some $\mathrm{Si}$ and $\mathrm{O}$ (Figure 11).

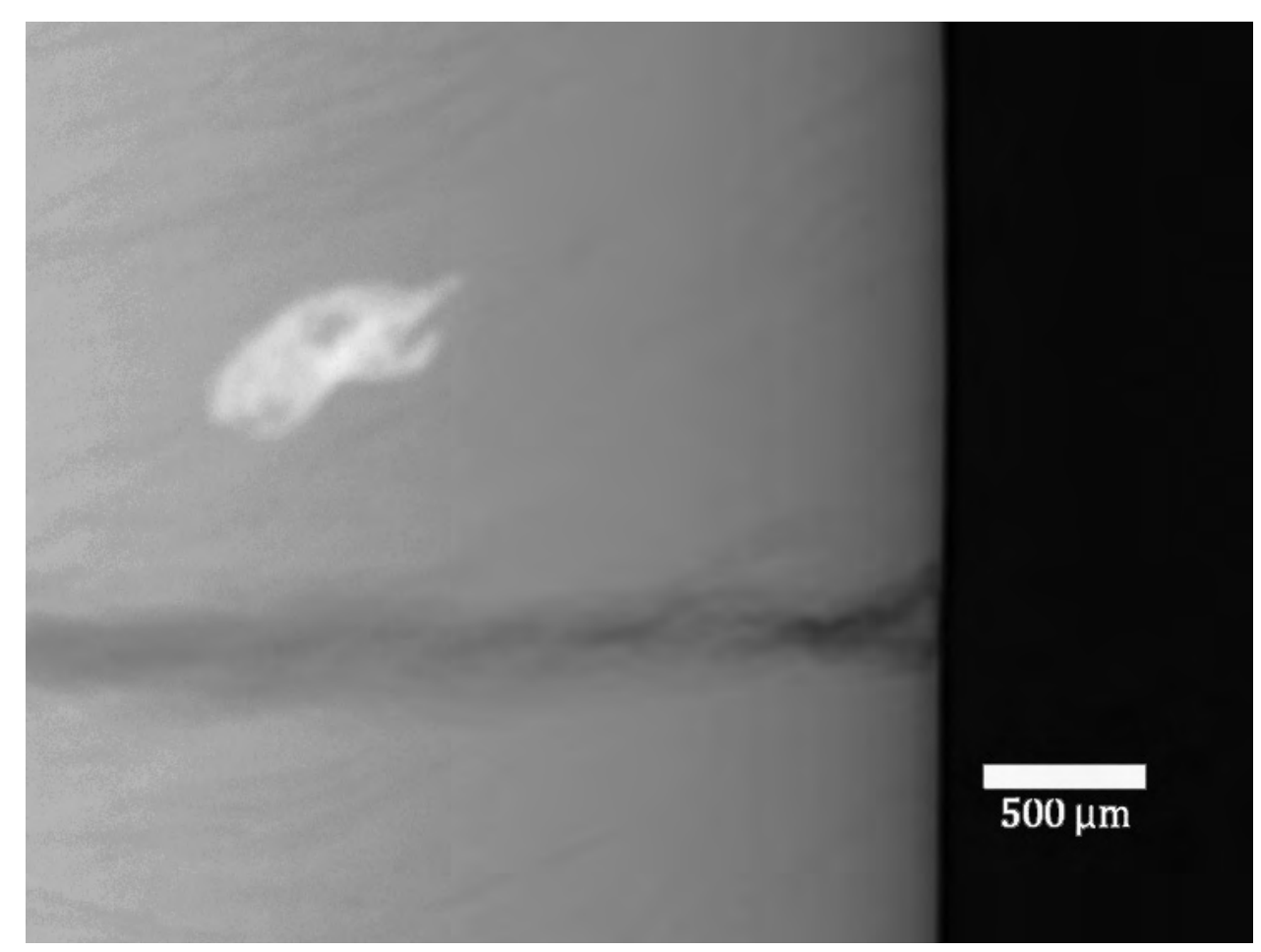

Figure 9. High resolution x-ray image of higher density inclusion in ARB-B1-Z006. 


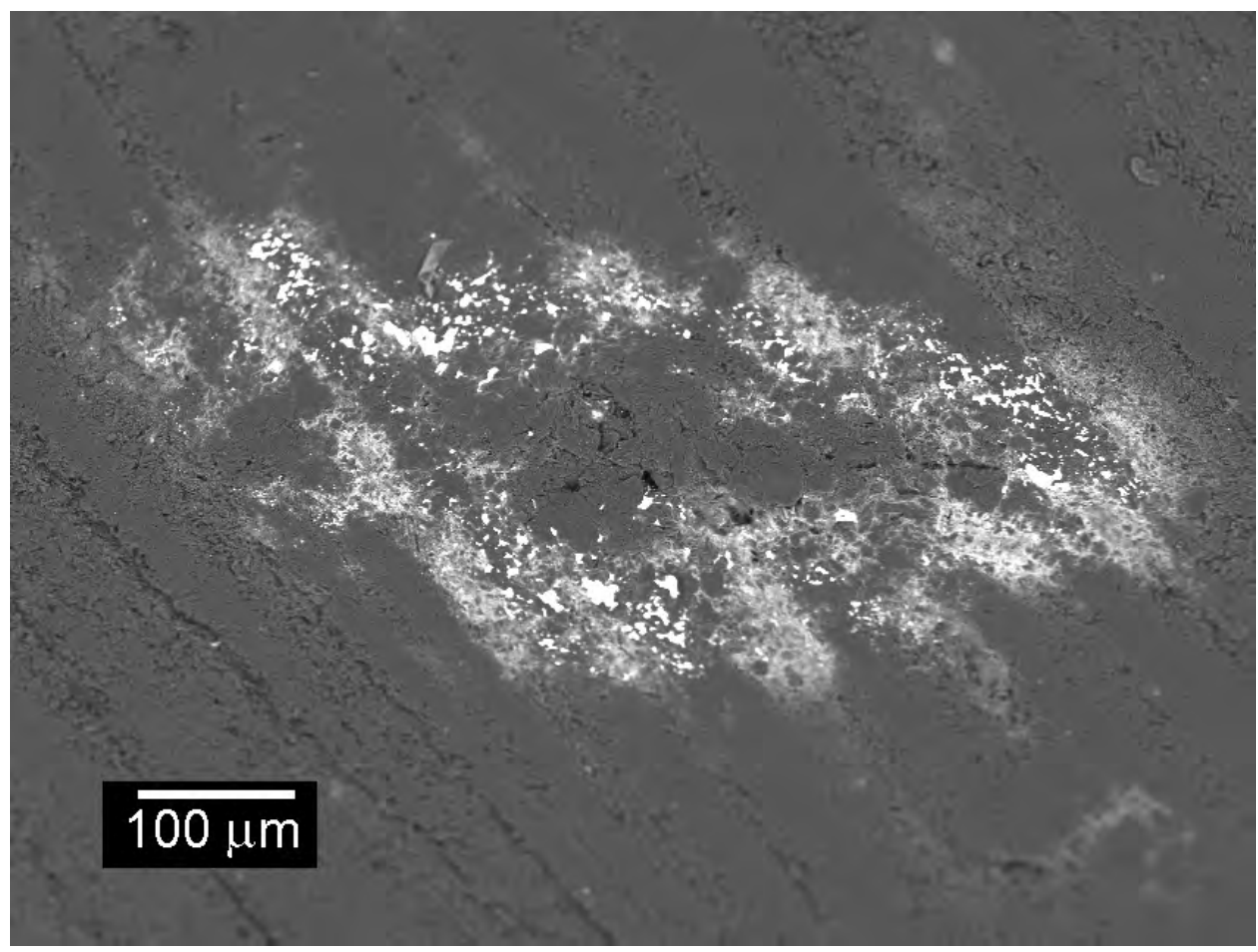

Figure 10. Back-scattered electron image of high $Z$ impurity in ARB-B1-Z006 after grinding away matrix carbon to exposed area.

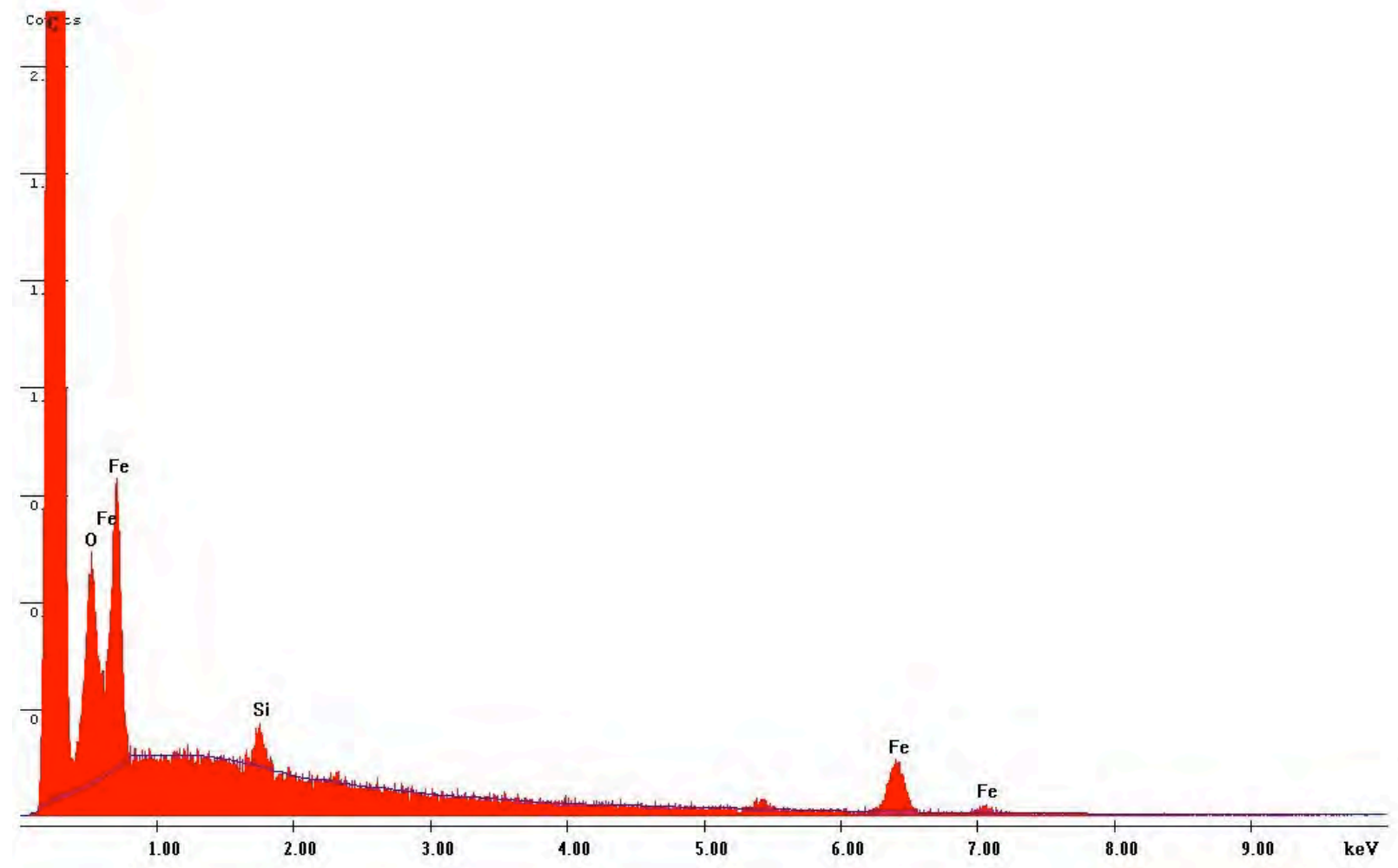

Figure 11. EDS spectra of impurity region in ARB-B1-Z006. 
A higher resolution x-ray image of the fragment in ARB-B1-Z034 is shown in Figure 12. This fragment was also not spherical and seemed to be aligned with the fissures. EDS analysis (Figure 13) showed mostly Si.

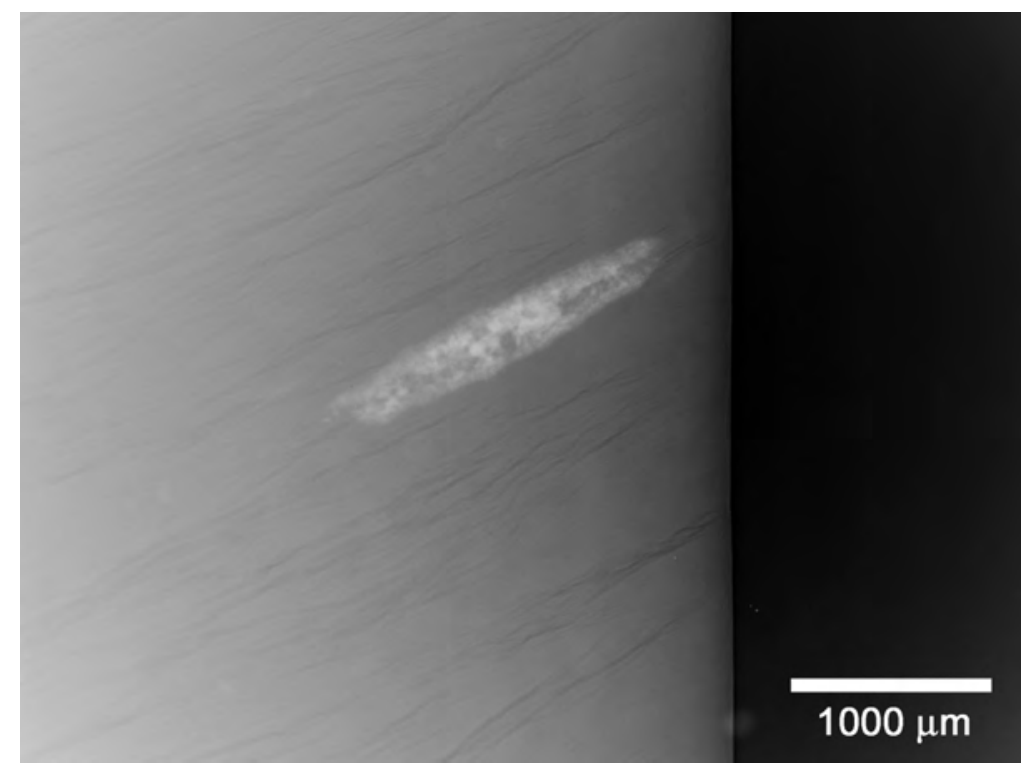

Figure 12. High resolution x-ray image of higher density inclusion in ARB-B1-Z034.

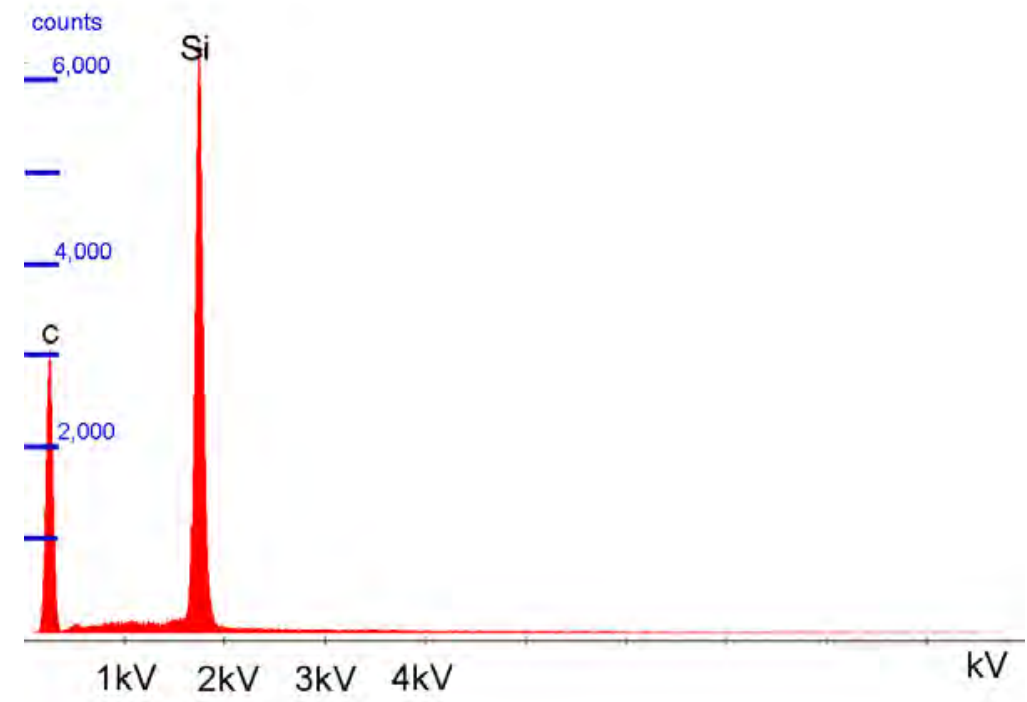

Figure 13. EDS spectra of impurity region in ARB-B1-Z034.

Ring blank ARB-B1-Z050 was analyzed by burn-leach. Uranium content in the first leach was relatively low at $2.37 \mu \mathrm{g}$ or $0.041 \mathrm{ppmw}$. This is equivalent to the amount of uranium detected in the least contaminated analysis set in Table 10, which indicates that the observed high density fragment did not contain uranium. Subsequent leaches or microwave digestion was not performed. 


\section{2) Consideration of the possibility that contamination was transferred to the ring blanks during heat-treatment.}

Uranium contamination in the tube furnace used for carbonization is unlikely given that a new quartz tube was used for this process. Uranium contamination in the graphite furnace used for heat-treatment to $1800^{\circ} \mathrm{C}$ is possible and has been identified as a concern based on previous analyses of fuel compacts, but a rigorous study to address the issue has not been performed. The heat-treatment furnace has been used for fabrication of fuel compacts and other fuel development studies which have resulted in contamination of the graphite internals. It was expected that this might introduce a small amount of uranium contamination in the ring blanks, but that the levels of contamination would be acceptable. To minimize possible contamination from the graphite internals, samples were placed within a graphite vessel with a loose fitting lid to allow for evacuation and backfilling with Ar.

RDKRS ring blanks were heat-treated in a single graphite vessel. However, because of a need to accelerate work to hold schedule, two graphite vessels were used for the ARB-B1 ring blank heat-treatment. One was the same graphite vessel used for the RDKRS ring blanks, but AGR-3/4 fuel compacts were heat-treated in this vessel between the RDKRS and ARB-B1 fabrication campaigns. Because the AGR-3/4 compacts contained DTF particles, it is possible that some uranium was transferred to the inside of the graphite vessel during this heat-treatment. The other graphite vessel had been used previously to study the performance of AGR-3/4 DTF particles during heat-treatment. Some of the DTF kernels were exposed during these tests, so it is likely that the graphite vessel became internally contaminated with uranium.

Table 11 lists the total uranium content and the ratio of $U-235$ to total $U$ measured from the first leach of the RDKRS ring blanks, which were fabricated prior to the ARB-B1 ring blanks. About $90 \%$ of the uranium content in the RDKRS ring blanks was detected in the first leach. Given the total uranium content measured in the ring blanks $\left(\mathrm{U}_{\text {Total }}\right)$ and the average enrichment of the uranium detected (E), it is possible to calculate the amount of low enriched uranium (LEU) and natural uranium (NU) in each sample by assuming that the uranium was present as either NU with $0.71 \%$ U-235 (coming from the natural graphite) or LEU with 19.7\% U-235 (coming from the AGR-3/4 fuel).

$$
\begin{gathered}
L E U=\frac{E-0.71 \%}{19.7 \%-0.71 \%} U_{\text {Total }} \\
N U=U_{\text {Total }}-L E U=\frac{19.7 \%-E}{19.7 \%-0.71 \%} U_{\text {Total }}
\end{gathered}
$$

From these calculations (Table 11), it appears that the majority of the uranium impurity in the RDKRS ring blanks came from the natural graphite. Note that the calculated content of NU was reasonably consistent for the 4 sample groups, which supports the conclusion that it came from the starting material. The LEU contamination picked up during heat-treatment was low compared to what was apparently already in the natural graphite and compared to the specified limit of $\leq 0.5$ ppmw $U$. 
Table 11. Uranium contamination from first leach of RDKRS ring blanks

\begin{tabular}{|c|c|c|c|c|c|}
\hline $\begin{array}{c}\text { Analysis } \\
\text { Group }\end{array}$ & Ring Blank IDs & $\begin{array}{c}\text { U in First Leach } \\
\text { ppmw }\end{array}$ & $\begin{array}{c}\text { Enrichment } \\
\text { U-235/U }\end{array}$ & $\begin{array}{c}\text { LEU } \\
\text { ppmw }\end{array}$ & $\begin{array}{c}\text { NU } \\
\text { ppmw }\end{array}$ \\
\hline \hline B & Z026,Z015,Z014 & 0.0155 & 6.5 & 0.0047 & 0.0108 \\
C & Z003,Z041,Z025 & 0.0185 & 8.0 & 0.0071 & 0.0114 \\
D & Z035,Z027,Z040 & 0.0137 & 4.9 & 0.0030 & 0.0107 \\
E & Z019,Z036,Z044 & 0.0136 & 4.6 & 0.0028 & 0.0108 \\
\hline
\end{tabular}

Table 12 through Table 14 list the total uranium content and the average enrichment measured from the first leach, second leach, and microwave digestion of the ARB-B1 ring blanks. Acid leaching was less efficient for the ARB-B1 ring blanks. With the exception of sample group D, about $65 \%$ of the total uranium content was detected in the first leach, $3 \%$ in the second leach, and $32 \%$ in the microwave digestion, and these fractions were fairly consistent from group to group. The calculated NU content was in good agreement for the first 3 sample groups. Sample group E had a higher calculated NU content than the other groups, and this discrepancy appeared to be real based on the fact that the relative fraction of NU detected at each step in the analysis was consistent with the other sample groups. The calculated NU content in the ARB-B1 ring blanks was 3-4x higher than observed for the RDKRS ring blanks. This is in agreement with observations that several impurities in the ARB-B1 natural graphite were also 3-4x higher than in the RDKRS natural graphite. For the set of ring blanks that showed an abnormally high uranium content, it is clear from the data that this uranium contamination came from a source that was around $19.7 \%$ enrichment. It is also significant that the other 3 ring blank sample groups also appeared to have a measurably higher LEU content compared to the RDKRS ring blanks. This indicates that the contamination may have been worse for this second set of ring blanks.

Table 12. Uranium contamination from first leach of ARB-B1 ring blanks

\begin{tabular}{|c|c|c|c|c|c|}
\hline $\begin{array}{c}\text { Analysis } \\
\text { Group }\end{array}$ & Ring Blank IDs & $\begin{array}{c}\text { U in First Leach } \\
\text { ppmw }\end{array}$ & $\begin{array}{c}\text { Enrichment } \\
\text { U-235/U }\end{array}$ & $\begin{array}{c}\text { LEU } \\
\text { ppmw }\end{array}$ & $\begin{array}{c}\text { NU } \\
\text { ppmw }\end{array}$ \\
\hline \hline B & Z026,Z015,Z014 & 0.0709 & 11.9 & 0.042 & 0.029 \\
C & Z003,Z041,Z025 & 0.0414 & 8.8 & 0.018 & 0.024 \\
D & Z035,Z027,Z040 & 1.865 & 19.4 & 1.836 & 0.029 \\
E & Z019,Z036,Z044 & 0.0832 & 7.9 & 0.032 & 0.052 \\
\hline
\end{tabular}

Table 13. Uranium contamination from second leach of ARB-B1 ring blanks

\begin{tabular}{|c|c|c|c|c|c|}
\hline $\begin{array}{c}\text { Analysis } \\
\text { Group }\end{array}$ & Ring Blank IDs & $\begin{array}{c}\text { U in First Leach } \\
\text { ppmw }\end{array}$ & $\begin{array}{c}\text { Enrichment } \\
\text { U-235/U }\end{array}$ & $\begin{array}{c}\text { LEU } \\
\text { ppmw }\end{array}$ & $\begin{array}{c}\text { NU } \\
\text { ppmw }\end{array}$ \\
\hline \hline B & Z026,Z015,Z014 & 0.0036 & 11.6 & 0.0021 & 0.0015 \\
C & Z003,Z041,Z025 & 0.0023 & 9.8 & 0.0011 & 0.0012 \\
D & Z035,Z027,Z040 & 0.0599 & 19.4 & 0.0590 & 0.0009 \\
E & Z019,Z036,Z044 & 0.0049 & 7.9 & 0.0019 & 0.0030 \\
\hline
\end{tabular}

Table 14. Uranium contamination from microwave digestion of ARB-B1 ring blanks

\begin{tabular}{|c|c|c|c|c|c|}
\hline $\begin{array}{c}\text { Analysis } \\
\text { Group }\end{array}$ & Ring Blank IDs & $\begin{array}{c}\text { U in First Leach } \\
\text { ppmw }\end{array}$ & $\begin{array}{c}\text { Enrichment } \\
\text { U-235/U }\end{array}$ & $\begin{array}{c}\text { LEU } \\
\text { ppmw }\end{array}$ & $\begin{array}{c}\text { NU } \\
\text { ppmw }\end{array}$ \\
\hline \hline B & Z026,Z015,Z014 & 0.0328 & 10.2 & 0.016 & 0.016 \\
C & Z003,Z041,Z025 & 0.0225 & 7.8 & 0.008 & 0.014 \\
D & Z035,Z027,Z040 & 0.0290 & 11.8 & 0.017 & 0.012 \\
E & Z019,Z036,Z044 & 0.0388 & 8.8 & 0.017 & 0.022 \\
\hline
\end{tabular}


The ARB-B1 ring blanks were randomly assigned Z-numbers as part of the product inspection plan, to support random QC sampling. The original G-number for each ring blank, which is associated with the actual fabrication order, is shown in Table 15. This table also indicates the carbonization and heat-treatment batch for each ring blank and whether each ring blank was used for burn-leach analysis, sent to INL, or retained in the ORNL archive (Group A). Analysis Group $\mathrm{D}$ was the one that was found to have a higher than average uranium content. This group contained ARB-B1-Z041(G010), which was the earliest fabricated ring blank of the 12 analyzed. If contamination was being transferred from a graphite vessel, this may have tapered off with each successive use and ring blanks fabricated early in the campaign may have been contaminated at higher levels. ARB-B1-Z041(G010) was the only ring blank analyzed from the second heat-treatment and none were analyzed from the first. Group D also contained ARB-B1Z027(G018) and ARB-B1-Z035(G047). These two ring blanks came from carbonization and heat-treatment batches that were incidentally sampled by ring blanks in Group E, which was determined to have an acceptable level of uranium contamination ( $0.127 \mathrm{ppmw})$. 
Table 15. Fabrication summary for ARB-B1 ring blanks

\begin{tabular}{|c|c|c|c|c|c|c|}
\hline Z-number & G-number & $\begin{array}{c}\text { Carbonization } \\
\text { Batch }\end{array}$ & $\begin{array}{c}\text { Heat-treatment } \\
\text { Batch }\end{array}$ & $\begin{array}{l}\text { Analysis } \\
\text { Group }\end{array}$ & At ORNL & At INL \\
\hline Z011 & G001 & 1 & 1 & & & $\mathrm{x}$ \\
\hline Z021 & G002 & 1 & 1 & & & $\mathrm{x}$ \\
\hline Z002 & G003 & 1 & 1 & & & $\mathrm{x}$ \\
\hline Z045 & G005 & 2 & 2 & & & $\mathrm{x}$ \\
\hline Z004 & G006 & 2 & 2 & & & $\mathrm{x}$ \\
\hline Z042 & G007 & 2 & 2 & & & $\mathrm{x}$ \\
\hline Z024 & G008 & 2 & 2 & & & $\mathrm{x}$ \\
\hline Z043 & G009 & 3 & 2 & & & $\mathrm{x}$ \\
\hline Z040 & G010 & 3 & 2 & $\mathrm{D}$ & & \\
\hline Z049 & G011 & 3 & 2 & & A & \\
\hline Z003 & G012 & 3 & 3 & $\mathrm{C}$ & & \\
\hline Z015 & G013 & 4 & 3 & $\mathrm{~B}$ & & \\
\hline Z009 & G014 & 4 & 3 & & & $\mathrm{x}$ \\
\hline Z032 & G015 & 4 & 3 & & & $\mathrm{x}$ \\
\hline Z019 & G016 & 4 & 3 & E & & \\
\hline Z017 & G017 & 4 & 3 & & & $\mathrm{x}$ \\
\hline Z027 & G018 & 4 & 3 & D & & \\
\hline Z029 & G019 & 4 & 3 & & & $\mathrm{x}$ \\
\hline Z028 & G020 & 4 & 4 & & & $\mathrm{x}$ \\
\hline Z038 & G021 & 5 & 4 & & A & \\
\hline Z047 & G022 & 5 & 4 & & & $\mathrm{x}$ \\
\hline Z001 & G023 & 5 & 4 & & & $\mathrm{x}$ \\
\hline Z031 & G024 & 5 & 4 & & & $\mathrm{x}$ \\
\hline Z005 & G025 & 5 & 4 & & & $\mathrm{x}$ \\
\hline Z023 & G026 & 5 & 4 & & & $\mathrm{x}$ \\
\hline Z022 & G027 & 5 & 4 & & & $\mathrm{x}$ \\
\hline Z020 & G028 & 5 & 4 & & & $\mathrm{x}$ \\
\hline Z008 & G029 & 6 & 4 & & $\mathrm{~A}$ & \\
\hline Z046 & G030 & 6 & 4 & & & $\mathrm{x}$ \\
\hline Z010 & G031 & 6 & 5 & & & $\mathrm{x}$ \\
\hline Z018 & G032 & 6 & 5 & & & $\mathrm{x}$ \\
\hline Z048 & G033 & 6 & 5 & & & $\mathrm{x}$ \\
\hline Z039 & G034 & 6 & 5 & & & $\mathrm{x}$ \\
\hline Z050 & G035 & 6 & 5 & & A & \\
\hline Z013 & G036 & 6 & 5 & & & $\mathrm{x}$ \\
\hline Z007 & G037 & 7 & 5 & & & $\mathrm{x}$ \\
\hline Z014 & G038 & 7 & 5 & B & & \\
\hline Z033 & G039 & 7 & 5 & & & $\mathrm{x}$ \\
\hline Z036 & G040 & 7 & 5 & $\mathrm{E}$ & & \\
\hline Z006 & G041 & 7 & 5 & & A & \\
\hline Z026 & G042 & 7 & 6 & $\mathrm{~B}$ & & \\
\hline Z041 & G043 & 7 & 6 & $\mathrm{C}$ & & \\
\hline Z034 & G044 & 7 & 6 & & & $\mathrm{x}$ \\
\hline Z044 & G045 & 8 & 6 & E & & \\
\hline Z012 & G046 & 8 & 6 & & A & \\
\hline Z035 & G047 & 8 & 6 & $\mathrm{D}$ & & \\
\hline Z030 & G049 & 8 & 6 & & A & \\
\hline Z037 & G050 & 8 & 6 & & & $\mathrm{x}$ \\
\hline Z016 & G051 & 8 & 6 & & A & \\
\hline Z025 & G052 & 8 & 6 & C & & \\
\hline
\end{tabular}


Ring blanks ARB-B1-Z011(G001) and ARB-B1-Z042(G007) were returned from INL to ORNL. These two ring blanks, along with ARB-B1-Z049(G011), were subjected to burn-leach analysis in order to sample additional ring blanks from the first two carbonization and heat-treatment batches and address the possibility of higher contamination levels in ring blanks fabricated at the beginning of the campaign. Table 16 shows the $U$ content detected by the first leach. Subsequent leaches or microwave digestion was not performed. Ring blanks ARB-B1-Z011(G001) and ARB-B1-Z042(G007) both showed U contaminations that were lower than what was detected in the initial burn-leach analysis (Table 10). ARB-B1-Z049(G011) was equivalent to the amount of uranium detected in the least contaminated analysis set in Table 10. There was no indication that ring blanks fabricated around the time of ARB-B1-Z041(G010) had unusually high uranium content.

Table 16. Additional analysis for uranium contamination in ARB-B1 ring blanks

\begin{tabular}{|c|c|c|}
\hline \multirow{2}{*}{ Ring Blank IDs } & \multicolumn{2}{|c|}{ U in First Leach } \\
\cline { 2 - 3 } & $\mu \mathrm{g}$ & $\mathrm{ppmw}$ \\
\hline \hline ARB-B1-Z011(G001) & 0.72 & 0.013 \\
ARB-B1-Z042(G007) & 0.65 & 0.011 \\
ARB-B1-Z049(G011) & 2.39 & 0.042 \\
\hline
\end{tabular}

It has been assumed thus far that contamination during heat-treatment would probably be dispersed in the blank and that contamination would occur equally to all ring blanks heat-treated together. It is also possible that uranium contamination could be transferred by contact to a heavily contaminated region within the graphite vessel. This would result in one or more ring blanks having a higher $U$ content than others fabricated and heat-treated at the same time.

\section{3) Consideration of the possibility that a particle got into the burn-leach vessel during analysis.}

It is unlikely, but can't be ruled out, that a particle may have gotten inadvertently mixed in with the ring blanks during analysis. Care is taken during burn-leach analysis to prevent cross contamination. Ring blanks are rinsed and blown off prior to starting the analysis. Quartz vessels are carefully cleaned between uses. The vessels are covered and high purity air is brought in to provide additional oxygen during the burn. The most likely scenario for contamination of the analysis would be for a particle to be picked up by static in the glassware during assembly of the reflux apparatus prior to leaching. There is no way to determine whether or not the unusually high uranium content in Group D was related to contamination during analysis. However, the general trace LEU contamination discussed above can not be explained by contamination during analysis. The analysis performed prior to the ARB-B1 burn-leach was a burn-leach of the RDKRS machined matrix rings. Results of this prior analysis were more than an order of magnitude lower, indicating contamination from the test apparatus is very unlikely. The burnleach on each set of samples was accompanied by a "blank" leach, where all analysis steps were performed in parallel using an empty vessel. The analyses of the blank yielded $U$ contamination values significantly lower than those observed for the ring blanks (0.1-0.2 $\mu \mathrm{g} \mathrm{U})$. 


\section{Conclusions}

Additional analysis was performed in an attempt to determine the source of the unusually high uranium content observed in one group of 3 ring blanks, compared to that observed for three other groups of 3 ring blanks each analyzed at the same time. Results were inconclusive in regards to what mechanism caused the observed high level of contamination or whether any other ring blanks were similarly affected.

X-ray analysis did not find any localized uranium contamination in any of the ring blanks not already destructively analyzed for the initial impurity analysis. Several non-graphite fragments were detected, but these were not uranium-bearing particles. The fact that these other small fragments could be detected demonstrated that the x-ray imaging had sufficient resolution to detect a similarly sized single particle of uranium contamination, if present. If the observed uranium contamination was related to a uranium bearing particle, such as an AGR-3/4 TRISO fuel or DTF particle, then it was an isolated anomaly and all other ARB-B1 ring blanks appear to be free of this defect.

Analysis and comparison of the burn-leach data to that obtained for the RDKRS ring blanks indicated that some general uranium impurity was present in all of the ARB-B1 ring blanks. The uranium impurity appeared to be a combination of natural uranium from the natural graphite and low enriched uranium from heat-treatment furnace contamination. There was no indication that the unusually high LEU contamination observed in the one offending sample group was related to any systematic trend in the fabrication order or heat-treatment grouping. Ignoring the unusually high result for the one sample group gives an average uranium content of $0.10 \mathrm{ppmw}$ with a standard deviation of 0.03 ppmw. Although this is below the specified limit of $\leq 0.5 \mathrm{ppmw}$ at $95 \%$ confidence, it is considerably higher than that observed for the RDKRS ring blanks (0.017 ppmw). This higher average uranium content in the ARB-B1 ring blanks was apparently due in part to a higher NU content in the natural graphite, as well as a higher LEU contamination level. The generally higher LEU content in the ARB-B1 ring blanks indicates a possibly worsening uranium contamination condition in the graphite heat-treatment furnace.

The observation of an unusually high uranium content in one of the four original burn-leach samples appears to be an anomaly, occurring either during fabrication or during analysis. It can not be concluded whether any other ring blanks may also have a uranium impurity content above the specified limit, but it is statistically favorable, based on the available data, to assume that no more than a few of the ring blanks would exhibit a uranium content significantly above the average of 0.10 ppmw obtained from the other 3 samples groups analyzed. 


\section{Appendix D: Certificate of Conformance}

On the following page is a copy of the Certificate of Conformance for the AGR-3/4 ARB-B1 ring blank lot. This is a record of the review by Quality Assurance personnel that specified requirements have been met or that any non-conformances to those requirements has been documented. The ARB-B1 matrix ring blank set did not meet all the product specifications for compact matrix ring blanks in section 1.05 of the AGR-3/4 DTF Fuel and Capsule Component Material Specifications (SPC-1214, Rev. 1). Three non-conformance reports were issued (see Appendices A - C). 


\section{Oak Ridge National Laboratory \\ Advanced Gas Reactor (AGR) Fuel Development and Qualification Program CERTIFICATE OF CONFORMANCE}

\section{ITEM IDENTIFICATION: AGR-3/4 Ring Blanks}

2. PART LOT AND LOT NUMBER: ARB-B1-Z

3. PRODUCT DEFINITION: INL Document SPC-1214, Revision 1 entitled AGR-3/4 DTF Fuel and Capsule Component Material Specifications

4. LIST OF APPROVED DEVIATIONS: Not Applicable

\begin{tabular}{|c|c|c|c|c|c|c|c|c|c|}
\hline $\begin{array}{l}\text { *Part } \\
\text { Type }\end{array}$ & $\begin{array}{c}\text { Unique Part } \\
\text { I.D. No. }\end{array}$ & Qty. & Init. & Date & $\begin{array}{l}\text { *Part } \\
\text { Type }\end{array}$ & $\begin{array}{c}\text { Unique Part } \\
\text { I.D. No. }\end{array}$ & Qty. & Init. & Date \\
\hline RB & ARB-B1-Z001 & 1 & PIA & $9 / 5 / 11$ & RB & ARB-B1-Z024 & 1 & $\mathbb{M}$ & $5 / 11$ \\
\hline RB & ARB-B1-Z002 & 1 & 4 & & RB & ARB-B1-Z028 & 1 & & $1 /$ \\
\hline RB & ARB-B1-Z004 & 1 & & & $\mathrm{RB}$ & ARB-B1-Z029 & 1 & & \\
\hline RB & ARB-B1-Z005 & 1 & & & RB & ARB-B1-Z031 & 1 & & \\
\hline RB & ARB-B1-Z007 & 1 & & & RB & ARB-B1-Z032 & 1 & & \\
\hline RB & ARB-B1-Z009 & 1 & 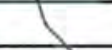 & & RB & ARB-B1-Z033 & 1 & & \\
\hline RB & ARB-B1-Z010 & 1 & & & RB & ARB-B1-Z034 & 1 & & \\
\hline $\mathrm{RB}$ & ARB-B1-Z011 & 1 & & & $\mathrm{RB}$ & ARB-B1-Z037 & 1 & & \\
\hline RB & ARB-B1-Z013 & 1 & & & $\mathrm{RB}$ & ARB-B1-Z039 & 1 & & \\
\hline $\mathrm{RB}$ & ARB-B1-Z017 & 1 & & & $\mathrm{RB}$ & ARB-B1-Z042 & 1 & & \\
\hline RB & ARB-B1-Z018 & 1 & & & $\mathrm{RB}$ & ARB-B1-Z043 & 1 & & \\
\hline RB & ARB-B1-Z020 & 1 & & & $\mathrm{RB}$ & ARB-B1-Z045 & 1 & & \\
\hline RB & ARB-B1-Z021 & 1 & & & RB & ARB-B1-Z046 & 1 & & \\
\hline $\mathrm{RB}$ & ARB-B1-Z022 & 1 & & & RB & ARB-B1-Z047 & 1 & & \\
\hline RB & ARB-B1-Z023 & 1 & & 1 & $\mathrm{RB}$ & ARB-B1-Z048 & 1 & & \\
\hline
\end{tabular}

\section{LIST OF APPLICABLE NONCONFORMANCE REPORT NUMBERS:}

NCR-X-AGR-11-01: Non-Conformance Report for Matrix Density

NCR-X-AGR-11-02: Non-Conformance Report for Al Content

NCR-X-AGR-11-03: Non-Conformance Report for U Contamination

With the exception of the Deviations documented on the forms referenced in Item 4 and the nonconforming conditions documented on Nonconformance Reports referenced in Item 5, the listed parts have been produced and tested in compliance to the requirements of the Quality Assurance Plan (QAP) for the AGR Program at ORNL (Document \# QAP-ORNL-AGR-01), its subordinate implementing procedures, and to the specified product definition prescribed in the document(s) referenced in Item 3.

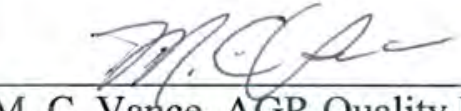

M. C. Vance, AGR Quality Representative, ORNL

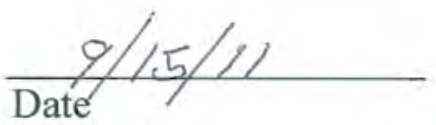

* RB indicates ring blank 